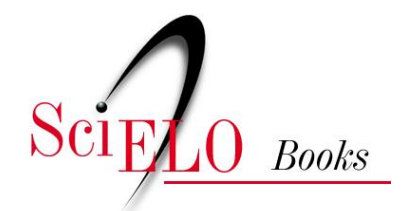

\title{
Identidades judaicas no Brasil contemporâneo
}

\author{
Bila Sorj (org.)
}

\section{SciELO Books / SciELO Livros / SciELO Libros}

SORJ, B. org. Identidades judaicas no Brasil contemporâneo [online]. Rio de Janeiro: Centro Edelstein de Pesquisas Sociais, 2008. 109 p. ISBN: 978-85-9966-260-1. Available from SciELO Books $<$ http://books.scielo.org $>$.

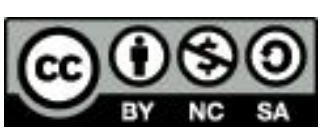

All the contents of this chapter, except where otherwise noted, is licensed under a Creative Commons Attribution-Non Commercial-ShareAlike 3.0 Unported.

Todo o conteúdo deste capítulo, exceto quando houver ressalva, é publicado sob a licença Creative Commons Atribuição Uso Não Comercial - Partilha nos Mesmos Termos 3.0 Não adaptada.

Todo el contenido de este capítulo, excepto donde se indique lo contrario, está bajo licencia de la licencia Creative Commons Reconocimento-NoComercial-CompartirIgual 3.0 Unported. 


\title{
Biblioteca Virtual de Ciências Humanas
}

\section{IDENTIDADES JUDAICAS NO BRASIL CONTEMPORÂNEO}

\author{
Bila Sorj \\ Organizadora
}


Bila Sorj

Organizadora
Esta publicação é parte da Biblioteca Virtual de Ciências Humanas do Centro Edelstein de Pesquisas Sociais - www.bvce.org

Copyright (c) 2008, Bila Sorj

Copyright (c) 2008 desta edição on-line: Centro Edelstein de Pesquisas Sociais Ano da última edição: 1997

Nenhuma parte desta publicação pode ser reproduzida ou transmitida por qualquer meio de comunicação para uso comercial sem a permissão escrita dos proprietários dos direitos autorais. A publicação ou partes dela podem ser reproduzidas para propósito não-comercial na medida em que a origem da publicação, assim como seus autores, seja reconhecida.

ISBN 978-85-99662-60-1

Centro Edelstein de Pesquisas Sociais

www.centroedelstein.org.br

Rua Visconde de Pirajá, 330/1205

Ipanema - Rio de Janeiro - RJ

CEP: 22410-000. Brasil

Contato: bvce@centroedelstein.org.br

Rio de Janeiro

2008 


\begin{tabular}{|c|c|}
\hline Apresentação & 01 \\
\hline $\begin{array}{l}1 \text { - Sociabilidade brasileira e identidade judaica } \\
\text { Bernardo Sorj }\end{array}$ & 03 \\
\hline $\begin{array}{l}2 \text { - Judeus na Amazônia } \\
\text { Eva Alterman Blay }\end{array}$ & 25 \\
\hline $\begin{array}{l}3 \text { - Conversões e casamentos "mistos": a produção de "novos } \\
\text { judeus" no Brasil } \\
\text { Bila Sorj }\end{array}$ & 57 \\
\hline $\begin{array}{l}4 \text { - "Normalizando" o povo judeu: a experiência da Jewish } \\
\text { Colonization Association no Brasil } \\
\text { Bila Sorj }\end{array}$ & 75 \\
\hline $\begin{array}{l}5 \text { - Diáspora minimalista: a crise do judaísmo moderno no contexto } \\
\text { brasileiro } \\
\text { Monica Grin }\end{array}$ & 90 \\
\hline $\begin{array}{l}6 \text { - Intelectuais na comunidade judaica brasileira } \\
\text { Roberto Grün }\end{array}$ & 109 \\
\hline
\end{tabular}

\section{Apresentação}

Bila Sorj

Referindo-se ao papel dos sociólogos na modernidade, Zygmunt Bauman caracteriza-os como legisladores, isto é, como responsáveis por formular diagnósticos e prognósticos sobre o conjunto da sociedade, identificar seus males e propor remédios. A agenda das Ciências Sociais no Brasil foi elaborada, até recentemente, dentro desta perspectiva, em torno do tema da construção do Estado nacional e seus grandes atores, as classes sociais. O estudo das identidades coletivas e da cultura foram elaborados no contexto desta problemática, particularmente em torno dos conceitos de "nacional" e "popular".

Na última década, com a democratização do país, com o surgimento ou fortalecimento de movimentos sociais que apostarei na diferença e na identidade própria e, particularmente, com os processos de globalização que deslocam os temas de identidade, cultura e etnia para planos supra ou infranacionais, começa a surgir uma preocupação maior com a formação de identidades e padrões específicos de grupos étnicos ou "raciais" que anteriormente eram desconhecidos ou subsumidos na problemática da estrutura social mais ampla da sociedade.

Este livro procura contribuir para o conhecimento de um setor da sociedade que não se enquadra nos temas tradicionais, na medida em que trata de um grupo cuja identidade cultural foge dos padrões e preocupações típicas do que foi a agenda dominante das Ciências Sociais no Brasil até bem pouco tempo. Apesar de os judeus terem um papel importante na construção de movimentos políticos e ideológicos, na vida econômica e científica do Brasil, são pouquíssimos os trabalhos que procuraram compreender os processos socioculturais de formação e transformação da comunidade judaica no Brasil. 
A presente coletânea reúne trabalhos - apresentados na III Conferência da Brazilian Studies Association realizada no King's College, Cambridge, em setembro de 1996 — de pesquisadores, quase todos, sociólogos de diferentes instituições. O resultado foi fecundo, não apenas pela variedade de temas abordados e diversidade de enfoques adotados, como pelo caráter pioneiro e polêmico dos trabalhos, que esperamos venham estimular outros pesquisadores.

Bernardo Sorj interpreta as características do judaísmo brasileiro como produto de um contexto muito particular, o de uma cultura onde práticas anti-semitas possuem pouco ou nenhum peso no cotidiano da maioria dos judeus. Eva Alterman Blay oferece uma visão das imigrações judaicas, apresentando trajetórias de famílias de judeus do norte da África que emigraram para a Amazônia, como exemplificações de percursos de integração dos judeus no Brasil. Bila Sorj aborda os casamentos "mistos" pelo ângulo daqueles que se convertem ao judaísmo procurando identificar as características sociológicas e o processo de "judaização" dos cônjuges. Em outro artigo, aborda a experiência da colonização judaica no Rio Grande do Sul, promovida por filantropos judeus, no início do século, mostrando como os valores que os orientavam foram retirados do discurso normalizador dos filosemitas não-judeus. Monica Grin, através de uma análise da Federação Israelita do Rio de Janeiro, examina a dinâmica institucional judaica a partir do tipo de interação que foi sendo desenvolvida com a sociedade mais ampla. Roberto Grin, comparando a comunidade armênia e judaica, indica o papel que os intelectuais judeus tiveram na construção de uma auto-imagem específica, que foi aceita pelo resto da sociedade.

Finalmente gostaríamos de agradecer a David Lehmann, da Universidade de Cambridge, pelo constante estímulo à organização do seminário e a Daniel Pecaut da École des Hautes Études en Sciences Sociales de Paris pela valiosa contribuição como debatedor dos trabalhos apresentados. Somos gratos, igualmente, ao Banco Safra pelo apoio que viabilizou a presença de vários participantes neste evento.
Sociabilidade brasileira e identidade judaica: as origens de uma cultura não anti-semita

Bernardo Sorj ${ }^{1}$

\section{Introdução}

Aparentemente, o estudo da comunidade judaica no Brasil não apresenta maior interesse sociológico. Um grupo pequeno, que não chega a ser $0,1 \%$ da população, ocupando majoritariamente setores sociais médios sem maior peso institucional na vida nacional, a comunidade judaica aparece como mais um componente do lado bem-sucedido e moderno, do Brasil contemporâneo. Acreditamos, porém, que a análise da dinâmica de integração dos judeus no Brasil pode ser particularmente instrutiva tanto para a compreensão da cultura brasileira, quanto do judaísmo e do antisemitismo modernos.

Assim, a cultura brasileira não discrimina o imigrante, pelo contrário, o valoriza. O país conseguiu absorver o maior contingente de população japonesa fora do próprio Japão, milhões de árabes e menor quantidade de judeus, sem gerar conflitos étnicos ou práticas preconceituosas. Trata-se de um feito admirável, possivelmente sem similares na história contemporânea. Grande parte destes imigrantes, numa sociedade com altos índices de crescimento econômico e mobilidade social, conseguiram rapidamente, graças aos valores e conhecimentos trazidos de seus lugares de origem, ascender socialmente e ocupar posições importantes nas classes médias e elites do país. A ascensão social dos imigrantes no lugar de gerar ideologias racistas ou sentimentos antiétnicos, é vista como fator positivo e valorizador da pessoa. Isto porque a cultura, a identidade e o mito de origem brasileiro favorecem a mudança, o novo e a transformação que permitirá realizar suas potencialidades como país do futuro. 
Este artigo procura desenvolver três temas, em forma de hipóteses preliminares. Em primeiro lugar, trataremos de compreender o fenômeno particular do limitado impacto do anti-semitismo no Brasil contemporâneo. A historiografia e sociologia judaicas do século XX têm sido especialmente sensíveis aos fenômenos anti-semitas nas diferentes sociedades onde radicam-se judeus. Elas têm se preocupado muito pouco, porém, em compreender porque em certas sociedades o anti-semitismo é reduzido ou quase inexistente. Em segundo lugar, procuraremos indicar algumas características do judaísmo brasileiro geradas pela integração na cultura e sociedade local. Finalmente procuraremos indicar certos padrões dominantes nos escassos estudos sobre o judaísmo brasileiro contemporâneo, numa perspectiva comparada com o caso argentino.

\section{Racismo e judeus no Brasil}

Partimos do pressuposto de que o Brasil é uma sociedade com baixos níveis de discursos ou práticas anti-semitas. Este pressuposto tem como base a informação cotidiana divulgada pelos meios de comunicação, relatos de imigrantes e a experiência empírica do autor como as avaliações de organismos especializados. O Antisemitism World Report indica que "There is no indication of state-sponsored antisemitism since the end of Vargas regime (1945, B.S.)" (p.10-11). "Brazil has little popular antisemitism" (p.13) (The Institute of Jewish affairs and the American Jewish Committee, 1995). Nos dois grandes centros onde se concentram a grande maioria dos judeus, Rio de Janeiro e São Paulo, práticas ou discursos anti-semitas que afetem seja a qualidade de vida e convivência social, ou que influenciem as chances efetivas de mobilidade social, são bastante excepcionais. Neste sentido, e voltaremos mais adiante a este ponto, o judaísmo no Brasil encontra-se numa situação diferente do resto da América Latina.

A explicação básica para a falta de anti-semitismo no Brasil pode ser procurada na particular ideologia brasileira do branqueamento (Skidmore, 1974). Nesta ideologia, o branco é o ideal a ser alcançado, de forma que as outras raças, particularmente a negra, poderão "melhorar", via miscigenação, até alcançar o branqueamento. Assim, na medida em que os judeus são aceitos como parte da raça branca — o que só foi questionado por alguns intelectuais brasileiros associados à ideologia fascista nas décadas de 20 e 30 — eles passam a ser parte da solução, e não um problema. Neste caso, embora a sociedade brasileira seja racista, antinegra, esse racismo não atingiria outras etnias, como os judeus.

Esta hipótese nos parece cobrir parte essencial da explicação a respeito do motivo de o Brasil não ser uma sociedade anti-semita, mas ela é insuficiente para compreender as formas específicas de integração, exigindo uma elaboração maior do debate em torno da ideologia do branqueamento e suas implicações sobre as diferentes formas de racismo, inclusive o antinegro.

As interpretações da formação sociocultural do Brasil no século XX se dividem em duas grandes linhas de força. Por um lado estão aqueles que enfatizam o caráter integrador da miscigenação, a cordialidade da psicologia coletiva, o sincretismo cultural, a porosidade social, em suma, uma sociedade aberta e tolerante, cujas origens remontam à particularidade da colonização lusitana, com predomínio de intenso intercambio sexual com as populações negras e nativas. No outro lado temos a versão que enfatiza as características racistas da estrutura social brasileira, na qual o negro não só ocupa os extratos mais pobres como sofre discriminação racial, tendo diminuídas suas chances de mobilidade social.

O racismo particular do brasileiro seria a ideologia do branqueamento, pelo qual o negro, através da mistura racial, passa a ser parte do mundo branco. Esta ideologia, dominante no Brasil, se expressaria na valorização dos filhos "mais brancos" de famílias com origem africana, e seria um desenvolvimento específico do moderno racismo europeu de finais do século passado. Como mostra Skidmore (1974), as elites brasileiras influenciadas pelas ideologias racistas deram uma interpretação particular para estas. Enquanto racistas europeus acreditavam que a miscigenação de raças no Brasil levaria a deterioração e degeneração racial do conjunto da sociedade, a ideologia brasileira do branqueamento supõe que a mistura racial, no lugar de ser uma perda de qualidades brancas, seria um ganho de qualidades para os negros, que passariam a integrar o plantel da raça virtuosa pela perda das características da raça viciada. 
A obra de Roberto DaMatta $(1979,1989)$ é uma das que com mais criatividade persegue a tese de que no Brasil, por trás de uma ideologia de cooptação universal, afabilidade, sincretismo e estrutura jurídica liberal, se esconde uma estrutura de poder hierárquica, profundamente desigual e racista. $\mathrm{O}$ argumento de DaMatta é o de que no Brasil predomina a fábula que apresenta brancos, negros e índios como sendo componentes equivalentes, no qual as três raças constituem o fundamento que deu lugar a um Brasil miscigenado e predisposto ao cruzamento e à tolerância racial. DaMatta procura mostrar que a sociedade portuguesa, cujas estruturas sociais foram transferidas para o Brasil, era uma sociedade com hierarquias fortemente marcadas, católica, dominada pelo formalismo jurídico, mercantil, e com laços de dependências entre as diferentes camadas dominantes. A fábula das três raças constituidoras do Brasil teria a função de integrar idealmente a população, depois da abolição, num marco comum, e que através do branqueamento, atingiria, algum dia, homogeneidade e harmonia. A ideologia da integração das raças, seja no plano sexual, da música, da mulher, do carnaval, mascararia a realidade das profundas diferenças de poder. Além disso, o próprio pressuposto da integração pelo branqueamento é profundamente racista e negador de uma identidade negra.

DaMatta contrapõe a ideologia da democracia racial e o aparelho jurídico de igualdade entre os cidadãos a uma prática social onde dominam profundas desigualdades, e onde a hierarquia do "você sabe com quem está falando" substitui a idéia de cidadãos com direitos iguais.

Assim, segundo DaMatta, a sociedade brasileira é profundamente hierárquica, sustentada na desigualdade entre as pessoas, onde os laços de dependência, pelas posições diferentes ocupadas na hierarquia social, ao mesmo tempo que permitem uma sociabilidade fundada na intimidade, confiança e consideração, desconhece os valores individualistas e igualitários. Nesta sociedade não há necessidade de segregação porque as hierarquias asseguram a superioridade do branco e a identificação do dominado com o dominador. O racismo moderno anglo-saxão, em contrapartida, seria num contexto de valores igualitários e individualistas uma forma de assimilar a diferença, porque em princípio é dominante a crença efetiva de que somos todos iguais. A segregação moderna pelo menos reconhece a alteridade do outro, enquanto no sistema hierárquico todo mundo é parte de um conjunto com um lugar desigual específico e as diferenças são relativas à posição ocupada por cada um. Este sistema permite todo tipo de graduação, vários níveis de "negritude", no lugar de oposições polares.

Sociedades hierárquicas como a brasileira, integram todo o mundo mantendo simultaneamente a desigualdade, enquanto no sistema igualitário e individualista a diferença só é suportável via segregação. Uma sociedade hierárquica é uma sociedade de mestiços onde existem as mais variadas cores de pele, no lugar de raças opostas. É o domínio do fenótipo e não do gene originador, das gradações de pele no lugar da pureza do sangue. A sociedade hierárquica brasileira, embora desigual, permite a conciliação e a cooptação das diferentes camadas que conseguem caminhar no sentido do branqueamento. A divisão da sociedade em infinitas camadas de nuanças de pele permite fugir ao confronto, pois neutraliza a formação de identidades nítidas. O Brasil seria, portanto, uma sociedade de um racismo moldado na hierarquia e não no individualismo.

O argumento de DaMatta não será discutido em detalhes, porém interessa indicar o que ele tem, além de iluminador, de problemático para a compreensão da dinâmica interétnica no Brasil. Interessa-nos em particular questionar aqueles aspectos onde DaMatta opõe ao modelo hierárquico brasileiro, o modelo individualista e igualitário anglo-saxão, a sua tendência a cristalizar padrões culturais perdendo de vista as mudanças sociais ligadas particularmente aos processos históricos de modernização e desconhecendo o caráter efetivamente contraditório da mitologia cultural brasileira, onde convivem componentes antiigualitários com um futuro coletivo comum utópico, assim como práticas sincréticas e ecumênicas.

A apresentação de DaMatta do mundo "anglo-saxão" como um todo coerente, não se sustenta. $\mathrm{Na}$ verdade, elementos contraditórios entre o nível político e práticas sócio-culturais são uma característica típica de todas as sociedades modernas. É suficiente mencionar os estudos de sociologia da sociedade francesa feitos por Bourdieu e toda a tradição anglo-saxônica que mostra como as sociedades liberais ocidentais se sustentam em valores tradicionais que lhe antecedem, e que tem como obra precursora os estudos de Weber sobre o protestantismo nas origens do 
capitalismo moderno (Bell, 1979).

No lugar de se ver na contradição entre a ideologia político-jurídico liberal brasileira e as práticas socioculturais hierárquicas um simples processo de mistificação no qual o primeiro plano encobre a realidade do segundo, é muito mais frutífera a análise da interação destes dois planos, tendo ambos efeitos reais no processo social.

Numa sociedade movida por uma ideologia consumista o preconceito racial passa a ser cada vez mais subordinado a capacidade aquisitiva do agente social. A definição do que seja branco cada vez mais se correlaciona com a posição econômica do indivíduo. As transformações sociais no Brasil contemporâneo geram uma sociedade com índices altíssimos de mobilidade social e renovam a composição social das elites econômicas e políticas. Novos processos sociais, por sua vez, como o empobrecimento econômico e cultural das populações pobres (com forte participação de negros e nordestinos) e a violência urbana geram novos focos de racismo.

DaMatta está errado em afirmar que a sociedade brasileira é cordial porque é hierárquica. A segunda característica não pressupõe a primeira. As sociedades hierárquicas em geral desconsideram, e mesmo repudiam, os estratos inferiores, com os quais têm pouca ou nenhuma comunicação. A sociedade brasileira é simultaneamente hierárquica e aberta, profundamente desigual e promotora da mobilidade social e da cooptação, é insensível com o coletivo e solidária com o seu grupo de referência. As sociedades hierárquicas tradicionais sempre tiveram um forte componente de fatalismo e fortes crenças na inevitabilidade e eternidade das diferenças. No Brasil, pelo contrário, as hierarquias se sustentam na expectativa da mobilidade social e de um futuro diferente. O próprio padrão de sociabilidade brasileira, gregário, lúdico, pouco individualizado, assim como seu sincretismo religioso, são expressões da forte absorção de elementos da cultura africana.

Porém, o que nos parece mais importante neste contexto é que o relato da mitologia nacional brasileira aparece incompleto na apresentação de DaMatta. Se por um lado ela supõe um claro componente racista na idéia do embranquecimento, ao mesmo tempo ela também inclui uma expectativa de homogeneização no futuro, que é alheio a uma sociedade efetivamente hierárquica. Em outras palavras, convivem no interior do mito nacional brasileiro uma idéia de pecado original - a composição negra, índia e marginal lusitana da população colonial - com a esperança de que o tempo, graças à riqueza infinita e beleza endêmica de sua natureza, permitirá eliminar estas manchas pela recriação de uma sociedade integrada e homogênea ${ }^{2}$. Esta visão do futuro limita e qualifica os componentes racistas da cultura brasileira.

A visão de uma sociedade que se sustenta na possibilidade de um futuro ideal comum e não na idealização do passado, é uma revolução copernicana em relação à toda a mitologia moderna dos Estados nacionais. Esta visão explica a quase inexistência de anti-semitismo, ou a fragilidade de ideologias antiimperialistas e que diferencia o Brasil do resto da América Latina.

Uma sociedade orientada para o futuro é uma sociedade que valoriza o novo e que não tem medo da inovação. O mito de origem do Brasil que encontra a origem dos problemas do país no passado, na escravidão e na colonização lusitana, e que acredita que o paraíso não foi perdido mas que se encontra no futuro, produz uma visão totalmente diferente dos valores da mudança e do estrangeiro. Na medida em que todos os mitos de origem nacional supõem uma fase áurea num passado remoto que nutre e sustenta os valores nacionais, eles criam uma relação problemática com o novo, identificado, quase sempre, com influências exteriores e o estrangeiro. $\mathrm{O}$ "nacional mais puro" é aquele que se encontra ligado mais profundamente às raízes e ao passado. Quanto menos se possuem estas raízes, mais longe se está dos "valores nacionais". No mito de origem brasileiro, pelo contrário, o passado é desvalorizado e sua proximidade com este implica numa identificação negativa. Não é à toa que no Brasil predominam as piadas sobre negros e portugueses como expressão do passado a ser rejeitado. Num contexto em que se valoriza o novo, a mudança e o futuro, o estrangeiro, no lugar de ser portador de valores estranhos à nacionalidade, passa a ser o principal construtor desta.

Enquanto nos mitos de origem nacional fundados no passado o inimigo é sempre externo e personificado nas "influencias estrangeiras", no

${ }^{2}$ Em relação à valorização da natureza pelos brasileiros cf. Carvalho, J.M., 1997. 
mito de origem brasileiro, do "país do futuro", o inimigo é interno, o próprio passado, personificado nos agrupamentos humanos associados a ele. É o passado que se trata de erradicar, para que a nação encontre seu potencial. Assim, por exemplo, se as ideologias antiimperialistas terceiromundistas se propunham superar e negar os aspectos do passado associados ao estrangeiro - agressivo e explorador — , para que o povo realize o seu potencial reprimido pela história, no caso brasileiro foi sempre dominante a visão do passado percebido como a fonte de todos os vícios, a que deveria ser superado para que possam ser realizadas as virtualidades do país, proporcionadas pelas suas riquezas naturais, à espera de serem exploradas sob forma racional no seu potencial de gerar prosperidade e riqueza para todos.

Toda cultura e mitologia nacional sustenta-se em experiências históricas e em processos políticos e sociais, que a reforçam ou transformam. A fragilidade de movimentos românticos e saudosistas no Brasil está associada à fluidez e à falta de confrontamento violento no interior das elites, que não permitiu cristalizar setores ressentidos e frustrados com as transformações sociais e desejosas de retornar a um passado idealizado. A classe dominante brasileira neste século não fez questão de associar suas origens à potência colonizadora para distinguir-se do resto da população nativa ou imigrante. A relação negativa com o passado limitou a formação de uma elite "tradicional", cujo prestígio se basearia em raízes "profundas" e que encarnaria a nacionalidade. Igualmente o papel econômico de São Paulo, liderado por grupos de migrantes, o cosmopolitismo do Rio de Janeiro, a inexistência de guerras ou inimigos externos relevantes, as altas taxas de crescimento econômico e a mobilidade social e espacial da população, todos eles convergiram para eliminar ou enfraquecer tendências xenófobas e românticas.

A ideologia "Brasil — país do futuro" se atualizou nos anos 50 pelo desenvolvimento de novas classes médias, geradas pelo processo de industrialização e modernização. As novas camadas que emergiram neste período são sustentadas num processo de crescimento econômico com taxas poucas vezes atingidas por outros países. Confiantes na capacidade da indústria, da ciência e da tecnologia em assegurar progresso social, estas camadas não só se afastaram da ideologia racial como valorizaram e absorveram nas artes expressões populares, ligadas em boa medida à população negra. As novas ideologias emergentes procuraram explicar os males do Brasil com referência exclusiva a processos econômicos e políticos com total exclusão do tema racial. Se a prática da valorização do branqueamento se manteve, seu discurso de sustentação ideológica deixou de ser legítimo.

Somente nos anos 80 e 90, com os períodos de estagnação econômica, desemprego crônico e aumentos de índice de criminalidade, começaram a surgir, ainda que marginalmente, expressões de discursos racistas, antinordestinos e antinegros.

O Brasil, como os brasileiros constantemente lembram, é um país sem memória. Aliás, esta é a única lembrança cultivada. Um país que alimenta a impunidade — nem a lei nem a memória condena atos passados —, que joga aparentemente toda experiência coletiva no esquecimento, parece ser, sem dúvida, um povo sem memória. Mas a "falta de memória" não expressa a falta de um mecanismo que deveria existir: ela é um produto histórico, construído socialmente, um mecanismo ativo, positivo, de uma sociedade que rejeita o passado como algo lastimoso, errado. A desvalorização do passado tem, por outro lado, efeitos perversos: não é possível construir um futuro se não se aprende do passado. Parece quase uma inversão da situação em que sociedades presas ao passado não conseguem criar um futuro diferente, obtendo em ambos os casos resultados similares.

Enquanto os mitos de origem que se sustentam na idealização do passado geram ideologias românticas conservadoras, antimodernas e antimercantis (o mercado é sempre visto como introdutor do novo e corruptor das tradições), a valorização do futuro faz do Brasil um país pouco permeável a este tipo de ideologia, e elas têm baixíssima expressão e são quase inexistentes no Brasil contemporâneo. Desta forma, o estrangeiro no Brasil em vez de simbolizar o perigo representa o progresso, as novas idéias e as práticas que poderão ajudar a sociedade a realizar seu destino de país do futuro.

No caso particular dos judeus, um outro fator que poderia sustentar sentimentos anti-semitas, o antijudaísmo que a igreja católica alimentou até 
recentemente, também dilui-se no contexto de uma sociedade onde predomina o sincretismo religioso. Estes sincretismo e diversidade religiosa que expressam a efetiva interpenetração de culturas no Brasil pelo fraco desempenho dos aparelhos ideológicos das classes dominantes, atuam, também ele, nos sentidos de uma absorção do novo, de não discriminar o diferente e de não desenvolver preconceitos frente a outras formas religiosas. As práticas sincréticas no Brasil igualmente expressam um universo onde a integração do outro não supõe a sua eliminação e sim sua absorção.

\section{O preço da integração brasileira}

Derrubadas as muralhas das autonomias jurídica e organizacional das comunidades judaicas tradicionais, o judaísmo moderno passou a interpenetrar-se com a sociedade local de forma tal que a identidade judaica, individual e coletiva, passou a ser parte integrante da sociedade nacional onde ela se encontra. Como já mostrou Salo Baron, o judaísmo sempre se desenvolveu em contato, reação e apropriação das influências do meio ambiente gentil. O que é novo na sociedade contemporânea é a diluição das barreiras institucionais que até então filtravam e limitavam o impacto do meio externo. Assim, embora sempre houvesse uma pluralidade de identidades judaicas locais na diáspora, estas nunca chegaram à intensidade integradora do mundo moderno. A modernidade para o povo judeu implicou numa barganha na qual recebia igualdade de direitos e abria mão de suas instituições jurídicas e de vida comunitária diferenciada. $\mathrm{O}$ direito à cidadania significou para os judeus a aquisição de uma identidade que os fazia parte de uma nova totalidade: a sociedade nacional. A modernidade implicou a separação existencial e política entre o indivíduo judeu e sua comunidade, quebrando os mecanismos de reprodução e socialização "natural" e colocando assim como uma questão permanentemente em aberto a continuidade da vida judaica e do sentido da identidade judaica.

A integração dos judeus no Brasil mantém naturalmente similaridades com os processos das outras regiões do mundo moderno, porém as especificidades da cultura e sociedade brasileira determinam o perfil particular das instituições e identidade do judeu brasileiro.

O Brasil, para o imigrante judeu vindo de regiões onde foi permanentemente discriminado e perseguido, teve muitas características de terra prometida. Ele se integrou na cultura nacional, passando a compor, na sua maioria, as classes médias, que se orgulham do fato de serem brasileiras. A sua rápida absorção na sociedade teve, como contrapartida, a constante erosão das fronteiras diferenciadoras e das tradições próprias. Uma sociedade que valoriza a sociabilidade gregária em torno de valores de convivência, que valoriza o lúdico no lugar de discursivo, ou o artístico no lugar da reflexão conceitual, é particularmente não condutiva para a constituição, na modernidade, de identidades étnicas diferenciadas.

A identidade judaica moderna, que se constituiu em cima de um esforço auto-reflexivo e como resposta ao anti-semitismo, não encontrou no Brasil condições propícias para seu desenvolvimento. Numa sociedade em que a integração social se dá ao nível de relações pessoais intensas, a distinção entre o público e o privado é frágil ou quase inexistente. Mas é na distinção entre o público e o privado, que no Brasil tem um espaço limitado, que se sustenta o desenvolvimento das novas formas de judaísmo na modernidade. Numa sociedade em que a "privacidade" não é um valor consolidado, não há espaço para desenvolvimento de uma consciência individual diferenciada - e angustiada -, e nem para a procura de raízes identitárias. Ser brasileiro é "curtir" a vida, procurar nos amigos um desafogo para os dramas existenciais e estar aberto ou ser muito tolerante a todas as formas de tradições religiosas e experiências místicas. Isto pouco se enquadra nas tradições judaicas de monoteísmo rígido, diferenciação ritual extrema entre o mundo judeu e não judeu e uma mitologia que se sustenta na valorização do passado, do sofrimento coletivo e na flexibilidade e angústia existencial.

A confirmação desta hipótese pode ser verificada, inversamente, pelo fato da comunidade do Rio Grande do Sul, embora muito menor que a do Rio de Janeiro e a de São Paulo (em torno de 20.000 indivíduos) apresentar o único caso de uma fundação cultural com um certo dinamismo (é a terra de origem do único romancista com uma obra literária com temas judaicos, Moacir Scliar). Isto porque o Rio Grande do Sul tem uma composição 
étnica predominantemente européia, com forte tradição localista, que cultua as tradições do passado "gaúcho", valorizando a reflexividade étnica e onde o anti-semitismo parece ser mais presente ${ }^{3}$.

Enquanto a cultura brasileira cultiva o esquecimento, a cultura judaica se sustenta na lembrança. A cultura judaica é uma cultura de angústia. Angústia implica insatisfação com o presente, vontade de mudar, enquanto a cultura popular brasileira, enfatiza o "deixa pra lá", viver o presente e esperar que surjam dias melhores. Enquanto o judaísmo se constitui numa atitude de "voluntarismo pessimista", a cultura brasileira é de um "fatalismo otimista", excelente antídoto para a depressão embora alimente irresponsabilidade social e a aceitação do status quo. A cultura brasileira, graças à influencia africana, tem no corpo e nas expressões artísticas a sua principal linguagem de comunicação, enquanto no judaísmo a hegemonia é a do conceito e da abstração.

Uma cultura que não teme, e que pelo contrário, confia no futuro e acredita no amanhã, é de um fatalismo otimista e é centrada no presente, pois o futuro não preocupa e o passado não oprime. $\mathrm{Na}$ tradição judaica, pelo contrário, o passado - seja na elaboração mitológica ou na memória histórica ainda presente — , faz do futuro algo temido, fonte de incertezas e angústia. O presente se transforma num espaço de preparação para futuras calamidades e de lembrança do passado, portanto esvaziado de conteúdo ou realidade própria. Se a convivência da mitologia judaica e brasileira não deixa de ser altamente terapêutica para os judeus, a elaboração de uma síntese implica num verdadeiro desafio.

O judaísmo brasileiro beneficiou-se do sincretismo e também participa dele. Embora não existam estudos quantitativos, a absorção de crenças e práticas espíritas e predisposição em utilizar serviços de curanderia originados de outras crenças é bastante difundido entre os membros da comunidade. A socialização familiar e particularmente a

${ }^{3}$ Inclusive as nuances que diferenciam o judaísmo paulista do carioca estão associadas a diferentes níveis de intensidade de dominância dos mitos nacionais brasileiros. Rio de Janeiro, capital do Brasil nos dois últimos séculos (até 1960), é a cidade que mais encarnou a mitologia nacional brasileira. São Paulo, que recebeu grande parte de seu contingente populacional no século XX, mantém identidades étnicas mais demarcadas. educação formal judaica, contudo, ainda estão centradas na criação de identidade via lembrança das perseguições e do anti-semitismo sofrido na historia, o que gera uma certa dissonância entre o discurso da tradição e a experiência efetiva dos judeus no Brasil.

Nas comunidades judaicas as elites econômicas mimetizam em boa medida as características do resto da classe dominante, incluindo a falta de um sentido público, a baixa predisposição ao mecenato e ao desenvolvimento de fundações de incentivo à cultura e ao conhecimento. Do ponto de vista da criação e cristalização de expressões culturais próprias, instituições e reflexão intelectual, o judaísmo brasileiro é de uma pobreza atroz. Esta pobreza de expressão coletiva sustenta-se no sucesso de sua integração individual. O judaísmo brasileiro, apesar de seu número limitado, teria um potencial de produzir formas revolucionárias de recuperação da mitologia e tradições judaicas dentro de um espírito de diálogo, confraternização e falta de anti-semitismo. Este potencial, porém, dificilmente se realizará. Para isto convergem várias forças internas limitadoras e a sociedade brasileira com sua força integradora.

A frágil comunidade judaica brasileira ficou totalmente exposta à colonização pelas tendências ideológicas e institucionais provenientes de Israel e dos Estados Unidos. Finalmente, a tendência de globalização cultural das classes médias - na qual os judeus estão majoritariamente inseridos -, dilui ainda mais as chances do desenvolvimento de uma tradição cultural judaica brasileira. Assim, embora claramente exista uma identidade nacional judaico-brasileira, isto é, judeus que se identificam com a cultura nacional e possuem uma forma judia de serem brasileiros e uma forma brasileira de serem judeus, ela não consegue cristalizar maiores expressões culturais ou institucionais de sentido coletivo.

Uma sociedade, onde mesmo na vida acadêmica predominam a cordialidade e as relações mútuas de dependência-clientelismo, e que portanto foge à confrontação e à individualização do debate intelectual, não favorece o desenvolvimento de um judaísmo discursivo-racional. É nas dimensões artísticas e místicas da cultura brasileira onde o judaísmo poderia encontrar um espaço maior de interação. É sintomático que o rabino Nilton Bonder, possivelmente o único autor com obras sobre judaísmo lidas 
por um amplo público judeu e não-judeu, explore a tradição do pensamento místico judaico ${ }^{4}$.

Isto obviamente não implica que a comunidade judaica tenha se diluído no característico amorfismo institucional brasileiro. Ela manteve e consolidou um sistema institucional que dá continuidade às suas tradições de valorização do ensino judaico, de solidariedade comunal e de apoio ao Estado de Israel.

\section{Estudos judaicos no Brasil}

A agenda das Ciências Sociais no Brasil, nas últimas décadas, deu pouco peso ao estudo do racismo ou das etnias de imigrantes que constituem a sociedade brasileira. A explicação para este fato se encontra, em boa medida, nos fatores mencionados anteriormente, de uma cultura nacional pouco disposta a valorizar a diferença e que renega as formas de racismo explícito.

Outros fatores convergiram para consolidar esta falta de preocupação. Na vida acadêmica, os estudos étnicos, em sua maior parte, se sustentam, no mundo todo, em financiamentos e no interesse dos próprios integrantes das etnias ou dos poderes públicos com preocupações relativas a conflitos étnicos. Como temos visto, no contexto brasileiro a auto-reflexão diferenciadora não é particularmente valorizada nem as elites "étnicas" se predispõem a atos de generosidade que incentivem este tipo de trabalho. $\mathrm{O}$ Estado, até recentemente, não tinha nenhuma preocupação com a problemática étnica ou a do racismo. Os próprios cientistas sociais, de diferentes origens étnicas, identificam-se por sua vez com uma agenda de pesquisa onde ressaltam os problemas sociais associados à classe, e recentemente a gênero, e onde praticamente não tem espaço outros tipos de recorte.

\footnotetext{
${ }^{4}$ A outra vertente que aproxima Bonder da sociedade brasileira, é um forte componente de literatura de auto-ajuda em seus livros: no Brasil, como nos Estados Unidos, os livros de não-ficção mais vendidos são predominantemente deste tipo.
}

Assim, a agenda das Ciências Sociais no Brasil teve, em geral, muito pouca sensibilidade para as dimensões étnicas da vida social. As preocupações teóricas no Brasil, como no resto das Ciências Sociais latinoamericanas se orientaram, em boa medida, pelo esquema conceitual marxista, pouco preparado para tratar o que B. Anderson (1991) denomina "comunidades imaginárias". O próprio marco normativo, centrado nas dimensões de dominação e exploração, procurando desenvolver projetos nacionais, valorizou análises centradas nas classes sociais e na unificação da nação em torno de um projeto comum. Assim, o tema da cultura e identidade aparece quase sempre ligado a preocupações com a "cultura popular" e um projeto nacional.

Os estudos sobre os judeus no Brasil contemporâneo são, portanto, poucos e esparsos. Inexistem centros de pesquisa, instituições ou publicações que possam ser considerados como referência intelectual e geradores de debates ou linhas de reflexão. Ainda assim pode-se comentar a bibliografia existente sobre o judaísmo no Brasil.

Em primeiro lugar, são raros os esforços autóctones de reflexão sobre a condição judaica no Brasil. Apesar dos inúmeros quadros judeus nas diferentes áreas das ciências do homem, é quase inexistente 0 desenvolvimento de uma reflexão específica sobre os judeus e o judaísmo. Possivelmente isto indica o próprio sucesso da integração na sociedade brasileira, que não gera no intelectual judeu angústias específicas.

Em segundo lugar, falta uma reflexão por parte da própria comunidade sobre as especificidades do judaísmo no Brasil. Abandonadas em boa parte pelos intelectuais judeus, majoritariamente seculares e com pouca participação na vida da coletividade, as lideranças comunitárias encontram-se numa situação defensiva, apoiando-se em discursos defasados e materiais educativos "importados" de Israel e em menor medida, dos Estados Unidos. Este discurso centrado no tema do anti-semitismo e da memória das perseguições sofridas pelo povo judeu leva muito pouco em consideração a experiência real do jovem judeu brasileiro.

Em terceiro lugar, os estudos de generalização do judaísmo latinoamericano realizados nos Estados Unidos e em Israel são bastante insensíveis às diferenças culturais e à especificidade brasileira. Assim, por 
exemplo, a distância enorme que existe entre a vida judaica na Argentina, onde o anti-semitismo é uma experiência cotidiana, e a vivência dos judeus no Brasil, não é suficientemente analisada.

Uma das características específicas da formação histórica da identidade nacional das elites brasileiras, que a diferencia dos outros países latino-americanos, é que o Estado nacional não se constitui através de uma confrontação armada entre suas elites e rompimento com o país colonizador. No Brasil não houve rompimento via guerra de independência e se constituiu desde o início como escolha de continuidade e renovação da Europa no Novo Mundo. Assim, a formação da ideologia do Estado nacional no Brasil foi um processo lento de afirmação das características próprias, enquanto na América hispânica a guerra contra a Espanha obrigou desde o início a que se criasse uma ideologia de afirmação pela negação, contra a potência colonizadora ou contra os vizinhos frente aos quais deviam ser afirmadas fronteiras arbitrárias.

Assim, enquanto no Brasil as raízes lusitanas foram sempre reconhecidas, na América hispânica a formação da identidade nacional deuse pelo rompimento com a potência colonial e a afirmação de símbolos pátrios centrados no poder do Estado. Desta forma, enquanto a ideologia nacional no Brasil não problematiza as raízes "estrangeiras" e aceita a continuidade histórica, no resto da América Latina, a afirmação contra o estrangeiro passou a ser parte da própria definição da identidade nacional.

A inexistência no Brasil, de um estado nacional com forte ideologia cívico-nacionalista, exigindo lealdade unívoca do "povo", fez com que a assimilação do judeu ao meio ambiente não tivesse sido vivida como uma questão de escolha entre a identificação com a "pátria" ou com a comunidade judaica. Fora da experiência comunista, onde a identificação com o partido exigia romper com outros vínculos de lealdade coletiva, a assimilação dos judeus no Brasil não implicou em um esforço ativo de autonegação. A Argentina, pelo contrário, apresentou um quadro muito diferente. Neste país, as suas classes dominantes saudosistas e mal integradas a contexto cultura nacional, a mobilização proto-facista das classes dominadas, o papel do catolicismo tradicional, a integração/normatização da ideologia cívica com forte componente "patriota", geraram uma sociedade permeada pelo anti-semitismo e que mobiliza em forma constante o problema da "dupla lealdade". Na Argentina, ainda, as forças de rejeição, da xenofobia e do anti-semitismo, geraram uma comunidade mais ativa, reflexiva e uma integração maior entre parte da elite intelectual judaica com a sua comunidade, apesar da crescente perda de densidade demográfica e cultural.

Cada cultura confere um equilíbrio particular entre o peso e a significação que tributam ao presente, ao passado e ao futuro. Em certos casos, como na Europa, na Argentina e no Uruguai, a valorização do passado como período de um esplendor que dificilmente voltará, faz com que o presente seja visto como um período de decadência e o futuro como anunciador de novas incertezas. Na cultura americana, o passado, não muito distante, oferece o sistema de valores e imagens de autoconfiança que permite transformar o presente numa plataforma para um futuro cheio de oportunidades e sonhos de auto-realizações. No Brasil a confiança no presente se alicerça na negação do passado e na capacidade de se afastar dele.

Finalmente, os poucos estudos sobre judaísmo no Brasil, geralmente feitos por historiadores, sublinham, em geral, aqueles episódios na história brasileira associados às expressões de anti-semitismo. Um exemplo paradigmático é o livro de Jefrey Lesser (1995), que apesar de importantes méritos, possui uma carga normativa que o leva a enfatizar a problemática da judeufobia e anti-semitismo e que o leva a distorcer a interpretação dos achados de sua própria pesquisa. Lesser focaliza o período das décadas $30 \mathrm{e}$ 40 no Brasil, durante a ditadura de Getúlio Vargas, inspirada em idéias fascistas. Neste período, ocuparam o governo alguns intelectuais que se inspiraram em ideologias anti-semitas européias para justificar políticas contra a emigração judia. $O$ trabalho de Lesser, que entre os vários méritos se encontra a ênfase na necessidade de reconhecer a especificidade da integração dos judeus no Brasil, não aplica este conselho em forma conseqüente.

Em primeiro lugar, Lesser não distingue suficientemente entre o discurso de alguns componentes do governo brasileiro e a realidade sociocultural do Brasil. Aliás, a distância entre o Estado e a sociedade no 
Brasil, é um tema constante das Ciências Sociais no Brasil. Assim, embora tenha ocorrido um surto anti-semita durante o Estado Novo, ele não chegou a ter maiores consequiências no que diz respeito à modificação dos padrões socioculturais da convivência brasileira.

A falta de anti-semitismo no Brasil não se explica, como coloca Lesser, pela inexistência de contato real com judeus concretos. De acordo com Lesser, quando os judeus efetivamente chegam ao Brasil e demonstram não serem "...neither very rich nor very poor, were rarely active politically, and rapidly acculturated to Brazilian society..." (p.3), as elites teriam perdido seus preconceitos. Não são os "fatos" que explicam a existência, ou perda, de preconceito no Brasil, ou em qualquer outra cultura. De todas as formas a colocação de Lesser é equivocada, pois houve no Brasil um número pequeno porém relevante de judeus que apoiaram o partido comunista, assim como outros conseguiram rapidamente ascender economicamente. Uma sociedade com predisposição anti-semita poderia ter mobilizado estes fatos para consolidar atitudes contra judeus.

Em segundo lugar, Lesser não é suficientemente sensível à compreensão da sociabilidade política brasileira, fortemente permeável a atitudes pragmáticas, ao compromisso e ao tratamento de cada caso individual como único, no lugar de atitudes burocráticas universalistas. Foi esta característica que permitiu o paradoxo sobre o qual Lesser tanto insiste: que apesar do discurso imigratório do regime de Vargas conter componentes anti-semitas, o número de imigrantes judeus ao Brasil de 1933 a 1942 foi superior ao da década anterior, ou ao dos países latinoamericanos com governos democratas e não anti-semitas.

As dicotomias da sociedade brasileira fogem à categorias de análises utilizadas por Lesser. Nela a dupla filo/anti-semitismo não constitui o parâmetro organizador da percepção social da alteridade no Brasil. Como indica Bauman (1995), é esta percepção do judaísmo como algo diferente, seja bom ou ruim, que determina a situação particular do judeu na cultura ocidental.

A ênfase de Lesser no tema do anti-semitismo e no discurso da elite intelectual deforma, portanto, a percepção da dinâmica política e social da vida brasileira e da integração dos judeus no Brasil. Afinal, como explicar que foi um governo semi-facista que aconselhado por um jornalista aparentemente anti-semita, Assis Chateaubrian, entregou nas mãos de um judeu um setor industrial politicamente estratégico, o da produção de papel (Morais, 1995).

\section{Conclusões}

$\mathrm{O}$ anti-semitismo tem sido uma das principais obsessões nos estudos judaicos deste século, porém pouco tem sido feito para compreender contextos em que o anti-semitismo é limitado ou quase inexistente. Este tipo de estudo pode contribuir tanto, ou quiçá mais, no esforço da erradicação do preconceito racial. Inclusive, para aqueles preocupados com a continuidade geracional do judaísmo, o esforço de entender e reconhecer a existência de contextos não anti-semitas é uma das condições para superar um discurso que valoriza o trauma e experiências não vividas pelas novas gerações.

A luta contra o anti-semitismo valorizou, fundamentalmente, as estruturas democráticas como barreira para a intolerância e como principal contraponto ao discurso racista. A experiência brasileira, sem negar ou desmerecer a importância da democracia, mostra que a luta contra o preconceito racial ou étnico pode se sustentar também nas estruturas culturais e mitológicas da sociedade. Inclusive, uma das contradições de muitos países democráticos avançados é a sustentação de uma educação cívica que valoriza mitos nacionais alimentados por ideologias xenófobas e racistas.

Toda identidade é incompleta sem uma imagem da alteridade. Os mitos de origem nacional na tradição européia se constituíram na contraposição, e por vezes na negação, do outro. Na cultura brasileira o outro é necessário para constituir-se a si mesmo. No lugar da degeneração, o estranho traz o progresso. Esta mitologia nacional se constituiu no preço altíssimo da desvalorização do negro. Contudo, a partir do passado brasileiro, esta construção não era a única saída possível. A originalidade da cultura nacional brasileira foi ter produzido uma sociabilidade que em muitos aspectos possui dimensões idílicas, pelo menos se visto da 
perspectiva das culturas individualistas e disciplinadas da Europa, onde o contato social e a convivência são fonte de angústia, o prazer é problemático e o presente inacessível. Esta cultura, por sua vez, dilui a alteridade, limitando a afirmação de identidades e da reflexividade discursiva, valorizando as relações primárias com descaso pela coletividade mais abstrata.

As culturas nacionais, no mundo moderno, não substituem a democracia como principal baluarte contra a intolerância, a violência arbitraria do Estado e mecanismo de resolução pacífica de conflitos. A cordialidade e a informalidade da sociedade brasileira, num contexto de desigualdade social e falta de direitos dos cidadãos, pode funcionar como um mecanismo de dominação, amenizando o confronto reivindicativo e evitando o conflito social. O grande desafio do Brasil é o de transformar a sociedade sem destruir os aspectos positivos de sua sociabilidade. A sociedade brasileira deve lutar por superar o racismo sem pretender usar tecnologias de regulação social, associadas a culturas que reprimem a espontaneidade, que se sustentam na afirmação da individualidade pela confrontação e na disciplina fundada na limitação das dimensões lúdicas da convivência.

O perigo é construir padrões sociais, via sistema jurídico e políticas públicas, que destruam os aspectos positivos da sociabilidade brasileira e que correm o risco de terem baixa eficácia na prática. No Brasil, parece haver um conflito entre os valores de sua sociabilidade e os valores democráticos. A proteção dos amigos e a insensibilidade frente ao bem público, o papel do clientelismo sobrepondo-se quase sempre a critérios universalistas, adquirem no contexto de uma sociedade que finca suas raízes no escravagismo e na miséria, uma dimensão de insensibilidade frente à desigualdade social e de incentivo à impunidade.

Conflitos entre valores não-individualistas (hierárquicos, coletivos) e a construção de uma sociedade democrática perpassam grande parte das sociedades (do Japão a Israel). Em sociedades com fortes componentes comunitários, - nacionalistas ou religiosos fundamentalistas - o desafio é a tolerância frente à diferença e a criação de um espaço público aberto ao reconhecimento do indivíduo como fonte última de escolha moral. A sociedade brasileira deve construir ainda a noção abstrata de cidadania e de um bem público comum, que implica numa solidariedade abrangente.

Da mesma forma que as democracias correm risco de existência, as culturas nacionais, embora sejam fenômenos de longa duração, são, também elas, um produto da história e mudam sob o impacto de novos contextos societários. Como mostra Poliakov (1971), a Suécia nos séculos XVI e XVII sustentou um mito de origem nacional que justificava o imperialismo e expansionismo territorial. Com as mudanças demográficas e políticas posteriores, os suecos refizeram seus mitos nacionais para adequálos às novas circunstâncias. $\mathrm{O}$ mito de origem dominante no Brasil também poderá vir a mudar. Os impactos da globalização, da individualização na vida urbana moderna, da pobreza, e das expectativas frustradas, poderão desgastar as crenças dominantes e abrir espaços a serem explorados por novos movimentos políticos e líderes carismáticos. O futuro do país do futuro é um livro aberto com novas páginas a serem escritas. No momento atual está longe de ser decidido em que direção os mitos e valores nacionais evoluirão.

\section{Bibliografia}

ANDERSON, Benedict. Imagined Communities: Reflections on the Origin and Spread of Nationalism. London: Verso, 1991.

BAUMAN, Zygmunt. Life in Fragments. Oxford: Blackwell, 1995.

BELL, David. The Cultural Contradictions of Capitalism, London: Heinemann, 1979.

BRUMER, Anita, Identidade em Mudança, Federação Israelita do Rio Grande do Sul, Porto Alegre, 1994.

CARVALHO, Jean Marcel. “Visões do Brasil e dos Brasileiros,” In T. Quigley, Lei e Liberdade: Forum 1996. Rio de Janeiro: Iser, 1997.

DAMATTA, Roberto. Carnavais, Malandros e Heróis: para uma 
Sociologia do Dilema Brasileiro. Rio de Janeiro: Zahar, 1979.

Relativizando: Uma Introdução à Antropologia Social.

Petrópolis: Vozes, 1989

IGEL, Regina. Imigrantes Judeus/Escritores Brasileiros, São Paulo: Editora Perspectiva, 1997

LESSER, Jeffrey. Welcoming the Undesirables: Brazil and the Jewish Question. Berkeley: University of California Press, 1995.

LEWIN, Helena. Judaísmo: Memória e Identidade, 2 vol., Universidade do Estado do Rio de Janeiro, 1997.

MORAIS, Fernando. Chato: o Rei do Brasil. São Paulo: Companhia das Letras, 1995.

POLIAKOV, Léon. Le Mythe Aryen. Paris: Calmann-Lévy, 1971.

RATTNER, Henrique. Tradição e Mudança, São Paulo: Editora Ática, 1978.

SACHAR, Howard, M. The Course of Modern Jewish History, New York: Vintage Books, 1990.

SKIDMORE, Thomas. Black into White: Race and Nationality in Brazilian Thought. New York: Oxford University Press, 1974.

SORJ, Bernando; GRIN, Mônica. Judaísmo e modernidade. Rio de Janeiro: Imago, 1991.

The Institute of Jewish Affairs/The American Jewish Committee, Antisemitism World Report 1995, Northamptonshire, 1995.

\section{Judeus na Amazônia ${ }^{1}$}

Eva Alterman Blay ${ }^{2}$

\section{Uma história oculta}

A presença dos judeus no Brasil não é, em geral, encontrada na historiografia brasileira. Nos livros escolares, nos compêndios universitários, não encontramos vestígios desta presença. É uma história oculta.

Inúmeras hipóteses podem ser aventadas para explicar esta e outras ausências, entre elas a de uma constante preocupação em definir o que seria a identidade brasileira. Com isso procurou-se enfatizar a homogeneidade cultural $^{3}$ em detrimento das diferenciações internas e da pluralidade cultural. Igualmente as Ciências Humanas, ao adotarem o critério racial para abordar a população brasileira, dividiram-na em três categorias brancos, negros e índios - e com isso reduziram as diferenças internas de cada grupo.

Entre as raras pesquisas - temáticas - que abordaram a presença judaica na população brasileira conta-se o trabalho da excelente historiadora Anita Novinski, ${ }^{4}$ que tem estudado continuamente a ação da Inquisição

\footnotetext{
${ }^{1}$ Parte deste texto foi apresentado na Reunião da Brasa, no King's College, Cambridge, em setembro de 1996. Foi escrito em Paris durante 1996, período em que lá estive cone moa bolsa de Pós-Doutorado da FAPESP.

${ }_{3}^{2}$ Prof. Titular de Sociologia - USP.

${ }^{3}$ Veja-se importante estudo ele Maria Isaura Pereira de Queiroz (1988) sobre várias correntes precursoras da Sociologia brasileira.

${ }^{4}$ Anita Novinski (1975). Novinski tem também orientado teses relativas ao tema. Veja-se o importante trabalho de Weisbrot sobre a Argentina e a Inquisição quando aquele autor mostra que Portugal permitira a emigração dos cristãos-novos para o Brasil de 1507 a 1568. Depois ficou proibido por 9 anos. Mas o pagamento de 1,7 milhões de cruzados e este tempo de interrupção permitiu a reabertura da imigração. Do Brasil muitos imigraram para a Argentina disfarçadamente.
} 
contra os judeus da Bahia no século XVII. Outros estudos importantes como os de Guinsburg e Berezin, o precursor trabalho de Pinski ${ }^{5}$ e esforços como os de Egon e Friedda Wolf são bases esparsas. Seus continuadores começaram a despontar nos anos 90 .

Em 1980, quando dei início à pesquisa "Os judeus na memória da cidade de São Paulo" (1890 a 1940), do qual este texto é uma das partes, decidi superar a lacuna bibliográfica recuperando parte do passado através da coleta das "histórias de vida" dos velhos imigrantes.

Todos nós, imigrantes e filhos de imigrantes, temos uma memória que se estende além de nossas próprias vivências. E a Memória das experiências ouvidas, narradas por aqueles com quem convivemos. Nossa vida é acrescida de outras emoções, tensores, esperanças. Encontrei, nas histórias de vicia que me foram contadas por judeus brasileiros e imigrantes, sínteses destas múltiplas experiências. Observei que pessoas de origens nacionais distintas trouxeram na bagagem outros costumes, valores, sofrimentos, alegrias, parentescos, antigos e visões políticas. Contudo, uma experiência era comum a todos: pobreza e perseguição.

Vidas distintas, observadas em conjunto, muito se assemelhavam. Esta coincidência não era fortuita, todos tinham em comuta a condição de judeus.

Entre eles existe uma certa reserva em revelar perseguições, seja por necessidade de esquecimento, seja por pudor ou para exorcizar a imagem do "eterno perseguido". Mas elas estão sempre nas entrelinhas das histórias contadas. São fundamentais para se entender a vicia social do grupo. E unia experiência vivida através de séculos de pogroms e que culminou com o Holocausto que atingir a todos aqueles que o viveram diretamente ou através de membros de suas famílias.

As histórias ouvidas não podem ser resumidas numa única história. No entanto, elas formam um conjunto peculiar. Aproximando-as vê-se que elas se entrelaçam numa trajetória comum, internamente diferenciada mas

5 Jaime Pinski (1975).

${ }^{6}$ Daniel Bertaux (1985); H. Avni et alii. (1989). compondo um conjunto com limites definidos.

\section{Judeus imigrantes}

Quando imigram para o Brasil, os judeus se distinguem dos respectivos grupos de mesma origem nacional, não são poloneses, romenos, tuas são judeus-poloneses, judeus-romenos, judeus-italianos, judeusfranceses, judeus-sírios, judeus-marroquinos... O qualificativo é uma marca que antecede o imigrante, formalmente pode nem estar em seus documentos, mas está difuso no imaginário do novo país como no país de origem.

Muitos autores se debruçaram sobre o complexo processo de imigração. Existe uma sintonia entre eles ao reconhecer que o imigrante avalia as perspectivas de sucesso, examina quando surgem áreas novas, procura fugir da pobreza e sabe o quanto é difícil sobreviver em seus países superpovoados ${ }^{7}$.

Os movimentos imigratórios teriam sido facilitados quando a Revolução Francesa derribou vínculos feudais, mudou o sistema de posse da terra, provocou rupturas na solidariedade familiar e comunitária. ${ }^{8}$ Em conseqüência, supõem que os indivíduos teriam se tornado livres para encontrar na imigração uma solução para a própria sobrevivência. ${ }^{9}$ Não se pode generalizar tais afirmações. Em primeiro lugar, porque as mudanças nas relações de dominação francesa e a extinção da condição servil não ocorreram na Rússia, Polônia, Romênia e em outras partes da Europa Oriental ou da África e, mesmo onde houve tais transformações, os judeus ficaram excluídos da plenitude dos direitos civis: não tinham o direito de se locomover no território, eram obrigados a morar em áreas determinadas, não tinham liberdade de trabalho, eram submetidos a numerus clausus na educação e, sob os mais fortuitos pretextos, eram vítimas de pogroms.

Quanto ao segundo aspecto, a ruptura das relações solidárias na comunidade, não há base histórica e sociológica que fundamente tal

\footnotetext{
${ }^{7}$ Petrone, 1978, pp. 93-180.

${ }^{8}$ Idem 1978.

${ }^{9}$ Idem 1978.
} 
generalização. No caso dos judeus ou de qualquer outro grupo imigrante deveriam ser comparadas às heranças sociais trazidas com o processo de reconstrução da vida social no novo país. É o que faremos a seguir analisando aspectos da imigração judaica, tornando a presença de judeus na região amazônica como paradigma e focalizando dois problemas.

1. Historicamente os judeus construíram, ao longo do tempo e em diferentes países, instituições para garantir a sobrevivência tísica, cultural e religiosa. Esta rede de instituições constituiu a base da comunidade judaica nos países de origem. Os imigrantes e as gerações posteriores tanto puderam mantê-las, ampliá-las ou reduzi-las. Estes processos de organização social foram também transferidos e mantidos no Brasil?

2. A imigração judaica contemporânea se (lá num momento de profunda transformação da sociedade brasileira, quando se constituía uma complexa cultura nacional, se expandia a economia capitalista-industrial e a identidade do país se definia face a outros países. Os grupos imigrantes poderiam percorrer vários itinerários nesta nação que se construía. Poderiam se dissolver no todo, manter unia identidade própria ou conciliar as duas possibilidades. Qual a interação que se estabeleceu entre imigrantes judeus e os processos culturais, econômicos, políticos e sociais do Brasil na etapa considerada?

\section{A longa viagem}

\section{Partindo para as Américas}

A partir da descoberta, as Américas receberam imigrações coletivas e particulares. ${ }^{10}$ No primeiro caso estavam as sucessivas expedições dos colonizadores espanhóis, portugueses, ingleses, franceses e holandeses.

${ }^{10}$ Estou chamando de coletivas aquelas patrocinadas pelos governos, do país de emigração ou de imigração. As particulares são aquelas em que um indivíduo ou sua família vem por conta própria, sem intermediação de nenhum governo. O único caso judaico que teve um caráter coletivo foi a Colonização da JCA (Jewish Colonization Association) no Rio Grande do Sul. Os judeus nunca tiveram um Estado que os representasse antes da criação do Estado de Israel.
Desde o início vieram também africanos escravizados. As imigrações particulares eram constituídas de pessoas de diversas nacionalidades, em geral homens sós ou famílias, deslocados por razões políticas, econômicas ou religiosas, sem a intermediação de governos ou outras instituições. ${ }^{11}$

No século XIX e no começo do século XX houve um forte crescimento nos movimentos imigratórios da Europa e do Japão para o Novo Mundo. Grandes levas populacionais deixaram seus países principalmente por razões econômicas: redução da produção agrícola, fome, grandes deslocamentos internos provocados pelo turbulento início da industrialização e da urbanização. O período foi também marcado por guerras, perseguições políticas e religiosas. Todos os países das Américas receberam imigrantes, mas em magnitudes diferentes. $O$ país que mais recebeu imigrantes foi Estados Unidos, seguindo-se de Canadá, Argentina e Brasil.

Entre 1890 e 1930 entraram no Brasil 3.523.591 imigrantes, dos quais 1 milhão de italianos, outro tanto de portugueses, 500 mil espanhóis, 100 mil alemães, 80 mil austríacos, quase 90 mil japoneses, 108.475 russos, 73.690 sírio-libaneses, além de outras nacionalidades como poloneses, tchecos, lituanos, húngaros, suíços etc ${ }^{12}$. Entre 1840 e 1942 entraram 71.360 judeus aproximadamente ${ }^{13^{3}}$.

Esta afluência decorre também de mudanças estruturais de caráter socioeconômico e político que marcaram de modo fundamental as duas últimas décadas do século XIX e as primeiras do século XX: 1. plenitude do capitalismo agrícola; 2. expansão do capitalismo industrial; 3. grande desenvolvimento econômico; 4. urbanização; 5. criação de amplo e diversificado mercado de trabalho; 6. extinção legal da escravatura; 7. mudança no sistema político com a proclamação da República. Estas condições constituíram forte atrativo à imigração para o Brasil.

Em síntese: o Brasil se transformava, abria-se largo espaço interno

\footnotetext{
${ }^{11}$ As imigrações judaicas para o Brasil foram particulares com exceção das colônias da ICA (Jewish Colonization Association), no Rio Grade do Sul.

${ }^{12}$ Petrone, idem. p. 101.

${ }^{13}$ J. Lestchinskv, 1972, p. 77
} 
para a produção de novos bens, para a invenção e para a criação no mundo cultural.

O café foi o produto que alavancou o desenvolvimento econômico brasileiro depois de 1850 . A exportação deste produto, altamente valorizado no mercado internacional, inseriu o Brasil numa posição econômica relevante e criou condições para o aumento da importação e intensa atividade financeira. Resultou em crescente produção industrial e urbanização ${ }^{14}$.

Uma economia tão capitalizada atraiu o investimento inglês que se aplicou na infra-estrutura agroexportadora, além de atrair o estabelecimento de ferrovias e portos que favoreceram, de rugi lado, a criação de condições para que fossem instaladas oficinas, pequenas fábricas e empresas de maior porte para a produção de bens de consumo interno como produtos de alimentação, e tecelagem e construção e, de outro lado, a expansão do mercado consumidor. Desenvolveu-se concomitantemente um grande setor urbano de serviços ${ }^{15}$.

O crescente mercado produtor e consumidor criou condições para a expansão do setor produtivo que requereu, em conseqüência, maior quantidade de força de trabalho especializada e braçal. Sucessivamente o governo imperial e o republicano elaboraram políticas para trazer imigrantes para a lavoura.

O governo imperial fez acordos com os governos alemão e italiano: em 1834 começam a chegar colonos alemães, e nos anos 50, os italianos. Acordos com o governo do Japão permitiram a vinda de trabalhadores japoneses para a agricultura em 1895. Empresários patrocinaram a imigração de famílias de trabalhadores italianos para suas fazendas de café; de ingleses e franceses para indústrias de tecidos e vidros respectivamente ${ }^{16}$.

Imigrantes de vários países também vieram com seus próprios

\footnotetext{
${ }^{14}$ Blay, 1985. Cardoso, Furtado; 1969.

${ }^{15}$ Blay, 1985.

${ }^{16}$ Blay, 1985 e 1987.
}

recursos ou ajudados por parentes imigrados anteriormente, atraídos pelo mercado de trabalho.

O maior contingente de alemães é da década de 1920, quando se registraram 65.839 imigrantes dessa origem. Nessa década aparecem pela primeira vez, registrados como tais, poloneses (24.110), lituanos (26.374), iugoslavos (22.127), além de húngaros e tchecos em menor número. Aparecem também os romenos em número significativo (28.626), embora já mencionados nos registros desde 1904. Ainda que não identificados nas estatísticas, havia judeus entre esses imigrantes e seus descendentes surgiram em nossa pesquisa de campo $^{17}$.

O censo de 1870, quando a escravidão ainda vigorava, indica que cerca de $94,5 \%$ da população brasileira era livre e 5,5\% escrava, ou seja, respectivamente 8.419 .672 livres e 1.510 .806 escravos $^{18}$. Na população livre incluíam-se os imigrantes que se distribuíam em variadas profissões, muitas delas desconhecidas no Brasil.

No fim do século XIX houve a grande explosão do "ouro Negro", a extração, comercialização e exportação da borracha da região amazônica. Uma massa de 500 mil migrantes nacionais e estrangeiros se dirigiu para a região - 200 mil no último decênio do XIX e 300 mil na primeira década do XX - atraídos pelas atividades econômicas ligadas à borracha. Segundo Prado e Capelato a maioria era constituída de nordestinos sendo de "pouca significação" imigrações estrangeiras.

No fim do século é o Sudeste - Rio de janeiro e São Paulo - que vai concentrar a maior população rural e urbana, processo que perdura até hoje. Em 1880 entraram em São Paulo 184 mil imigrantes; entre 1890 e 1920 o número cresceu para 1.500 .000 , praticamente $70 \%$ do total dos imigrantes que entraram no país.

\footnotetext{
${ }^{17}$ Fanny Rubinstein Née Tabacof; Sra. Malvina Teperman, Sra. Klabin entre outros. ${ }^{18}$ F.H. Cardoso, 1977, p. 17, apud Censo de 1872.

${ }^{19}$ Prado e Capelato, 1977 , p. 291 e p. 93-180.
} 
Quadro 1

Imigração no Brasil e em São Paulo ${ }^{20}$

\begin{tabular}{|c|c|c|}
\hline Período & Brasil & São Paulo \\
\hline $1880-$ & - & 184.000 \\
\hline $1891-1900$ & 1.129 .315 & 733.335 \\
\hline $1901-1920$ & 1.469 .095 & 857.149 \\
\hline
\end{tabular}

Fonte: Randão Lopes apud Cardoso (1977).

Dos 3,5 milhões de imigrantes que entraram no país no período 18901930, 2 milhões foram para São Paulo. Com tal fluxo o Estado brasileiro muda sua política imigratória e depois de 1927 os imigrantes de alguns países passam a ser subvencionados pelos governos de origem interessados em resolver problemas internos de superpopulação e desemprego.

Entre 1917 e 1924 os Estados Unidos elaborou uma legislação que restringia fortemente a entrada de estrangeiros. Nos fins da década de 20 a América Latina o imita. Getúlio Vargas, em dezembro de 1930, decreta um controle para a entrada de estrangeiros pois os considera responsáveis "pelo desemprego verificado entre as populações urbanas". ${ }^{21}$ A partir de então começam medidas de caráter protetor nacionalista como a "lei dos $2 / 3$ ", isto é, as empresas são obrigadas a empregar 2 brasileiros natos para cada 3 contratados. São também estabelecidas "quotas de $2 \%$ dos imigrantes de cada nacionalidade chegados nos últimos 50 anos".

Na Europa e no Oriente os problemas demográficos e econômicos continuaram os mesmos e certamente se agravaram em virtude de razões políticas, da ascensão do nazismo em 1933 na Alemanha, de revoluções e

\footnotetext{
${ }^{20}$ IBGE e Dep. Estadual de Estatística de São Paulo tabela 6 apud Brandão Lopes e Cardoso, p. 22.
}

${ }^{21}$ Idem, p. 97 da $2^{\text {a }}$ Guerra Mundial. Formalmente, a porta de entrada do Novo Mundo tinha se fechado. Na verdade houvera um estreitamento da passagem e os fluxos imigratórios continuaram a ocorrer. Podiam entrar pessoas com capital, trabalhadores especializados e também facilitavam-se os reagrupamentos familiares. Isto foi vital às vésperas da $2^{\mathrm{a}}$ Guerra Mundial, especialmente para os judeus perseguidos nos países dominados pelo nazismo.

\section{Judeus imigram para o Brasil}

\section{O período colonial}

O movimento imigratório judaico para o Novo Mundo seguiu exatamente a mesma trajetória das imigrações em geral. Os judeus fizeram parte das esquadras dos navegantes descobridores portugueses e espanhóis. Eram astrônomos, geógrafos, escribas, homens do mar.

A colonização portuguesa trouxe para o Brasil uma visão controvertida sobre os judeus. As posições antijudaicas ${ }^{22}$ expressas por frei Amador Arrais, por João de Barros e por D. Francisco Manuel de Melo vão encontrar respostas em Gil Vicente, no padre Antônio Vieira, em Camilo Castelo Branco e em Alexandre Herculano. Diz Lafer: "Uma literatura é marcada por sua época (embora nela também imprima a sua marca), e essa marca do tempo se transmite, através dela, a épocas futuras" ${ }^{23}$. Assim a literatura revela posições que expressavam antijudaísmo e outras que, ao se rebelarem contra esta visão discriminatória, expunham como a hierarquia da Igreja católica e certos grupos da população portuguesa se aproveitavam dos bens materiais dos acusados ${ }^{24}$. Embora difícil de avaliar, a influência desta literatura nas gerações futuras não pode ser ignorada.

${ }^{22}$ Celso Lafer, 1962, p.115. "A obra de Gil Vicente constitui excelente ponto de partida para um estudo do judeu, por intermédio da literatura luso-brasileira. De fato, nela se encontra embrionárias, na sua maior parte, as perspectivas dos diversos autores, do cante vários séculos" (p. 106).

${ }^{23}$ Idem, p. 106.

${ }^{24}$ É paradigmático o romance $O$ Judeu de Camilo Castelo Branco (1970) a respeito da perseguição e morte do dramaturgo brasileiro Antonio José, O judeu. 
A inquisição na Espanha e Portugal já tinha expulsado os judeus daqueles dois reinos e muitos deles tinham se refugiado no Norte da África, outros na Holanda. Com a instalação da Companhia das índias Ocidentais no Brasil, algumas famílias judias acompanharam o príncipe Maurício de Nassau e se fixaram em Pernambuco. Dedicaram-se à comercialização e ao financiamento da produção açucareira. ${ }^{25}$ Em 1645 havia em Pernambuco 14.500 moradores (brancos, negros e índios). Os judeus eram 1.500 dos 6.500 brancos.

Sob dominação holandesa, tinham liberdade de culto ${ }^{26}$ e constituíram a "primeira comunidade" do país, "Tzur Israel" (Rocha de Israel), que trouxe, em 1624, o importante rabino Isaac Aboab da Fonseca ${ }^{27}$. A presença deste rabino indica que estavam estabilizados na região e tinham recursos para arcar com a vinda e manutenção de tal personalidade. "A comunidade era próspera e se organizou nos moldes das "kehilot" (comunidades) tradicionais: mantinha-se com o imposto sobre as transações comerciais dos judeus e era governada pelo Maamad ou Conselho de cinco membros, eleitos anualmente. O Maamad controlava todos os aspectos legais da vida dos judeus, exercendo autoridade judicial, impondo multas e regulamentando as relações internas da comunidade" ${ }^{\text {,28 }}$, afirma Berezin.

A permanência holandesa perdura por 30 anos. Com a retirada de Nassau, metade dos judeus holandeses, temerosos de serem novamente perseguidos pela Inquisição, deixam o Brasil; alguns o acompanham, outros se instalam em países da América Central e na Nova Amsterdã, na ilha de Manhattan, depois New York. Cemitérios do século XVII, com lápides em

${ }^{25}$ Rifka Berezin, 1975. Este é um fato histórico controverso.

${ }^{26}$ Autores como Novinski, Berezin, afirmam a liberdade religiosa ao passo que Buarque de Hollanda (1976, org.) informa que houve "perseguição aos israelitas" por parte das autoridades holandesas (p. 241). A contradição entre estes autores mostra como o assunto, ainda precisa ser estudado. É certo, porém, que haviam sido construídas as sinagogas Zur Israel (em Recite), a Maguem Abraham em Mauricia e outras na Paraíba e em Penedo. Segundo Hollanda, "os israelitas" foram vítimas de "uma verdadeira campanha anti-semita", pois "quase todos os negócios passavam-lhes pelas mãos e daí o ódio que contra eles acumularam os seus concorrentes holandeses" (p. 248).

${ }^{27}$ Isaac Aboab da Fonseca é considerado o autor do primeiro texto escrito em hebraico nas Américas; "Zekher asiti liniflaot El" (Erigi um Memorial aos milagres de Deus), composto em Recife em 1646 (Hollanda, 1976, p. 249).

${ }^{28}$ Berezin, 1975, p.2-13. hebraico e português, são testemunhos deste trajeto.

Em 1654 quando Pernambuco foi reconquistada pelos portugueses, 600 judeus permaneceram no Recife ${ }^{29}$.

$\mathrm{Na}$ mesma época os "cristãos-novos", judeus convertidos, são encontrados na Bahia onde tinham começado a chegar desde o início do século XVI e onde foram submetidos a situações muito contraditórias. As mesmas restrições de "pureza de sangue" do Concílio de Latrão de 1215, que vigoravam na metrópole, foram impostas à colônia, os "cristãos-novos" passaram a ser considerados "sangue impuro". A Inquisição ratificou que filhos e netos elos "hereges" não podiam "desempenhar funções públicas na índia, não podiam ser boticários, nem médicos, nem ser admitidos a nenhuma cadeira da Universidade. Não podiam pertencer às ordens militares, nem negociar na Bolsa e cogitava-se de medidas que os impedissem de casar com cristãos-velhos [...] Não podiam ser fidalgos nem ter honra alguma". Sol a alegação de que prejudicavam os "naturais" tentou-se impedir que exercessem o comércio. Os casamentos mistos, isto é, com cristãos-velhos, seriam punidos e o castigo atingiria os descendentes impedindo-os até mesmo de andar a cavalo, ou que suas mulheres e filhos andassem de coche ou cadeira ${ }^{30}$. Estas formas de discriminação, socialmente visíveis, tinham por objetivo mostrar com clareza que os judeus eram um grupo inferior, impuro, "párias" ${ }^{, 1}$ da sociedade.

Na colônia as imposições da Inquisição eram obedecidas de maneira mais flexível, mas sempre existia o medo de uma denúncia, de um processo, da prisão, da tortura e da pena de morte. Novinski acata a hipótese de que esta permanente desconfiança seria responsável "pelo comportamento de uma população desconfiada, insegura e extremamente crítica", que ela identifica na "personalidade do homem brasileiro"32. Hipótese difícil de provar mas bastante sugestiva face aos dados que ela apresenta: os "familiares", isto é, fiéis servidores da inquisição, recebiam pagamentos por

${ }^{29}$ Idem, p. 243

${ }^{30}$ Novinsky, 1972, p. 51.

${ }^{31}$ Idem, p. 58. Punições semelhantes eram usuais no Sul da França, em Avignon ver René Moulinas.

${ }^{32}$ Idem, p. 58. 
dia de serviço, além de ordenados e outros proventos por cada auto-de-fé. "O total de propinas nos autos-de-fé era de 350\$000, sendo o total de despesas $144 \$ 760^{33}$. Entre 1624 e 1654 “A Bahia [...] estava abarrotada de 'familiares ${ }^{34}$, pessoas regiamente pagas para delatar. E, como se sabe, a primeira providência da Inquisição era sempre se apropriar dos bens dos 'hereges', isto é, dos judeus acusados de praticar a antiga religião".

Saraiva ${ }^{35}$ para Portugal, Netanyahu ${ }^{36}$ para a Espanha, Karady ${ }^{37}$ para o Império austro-húngaro, Novinsky ${ }^{38}$ para o Brasil consideram que os mecanismos postos em prática para perseguir os judeus, despojá-los de seus bens, impedi-los de ocupar posições econômicas, políticas, enfim, de se inserir na sociedade, foi uma forma de reprimir o fortalecimento da burguesia ou de parcelas da burguesia que cresciam nestas sociedades. Excluir os judeus era uma forma de barrar um significativo grupo da camada burguesa $\mathrm{cm}$ ascensão e de resguardar o poder da minoria aristocrática.

Judeus, mouros ou negros, todos tinham sangue "infecto" e como tal constituíam unia "casta" excluída de posições ou cargos mais elevados. Deveriam se manter sujeitos à aristocracia, ao poder dominante e deveriam ser desprovidos de liberdades que pusessem em risco monopólios e privilégios. Entretanto, na colônia as regras foram mais flexíveis e alguns "cristãos-novos" receberam sesmarias, tiveram propriedades, tornaram-se senhores de engenho, produziam e negociavam açúcar e chegaram a ocupar posições políticas assim como cargos públicos. A situação vivida era bastante contraditória, com permanente ameaça da Inquisição. E paradigma desta situação de intranqüilidade a morte, na fogueira da Inquisição, do dramaturgo brasileiro Antônio José da Silva, o judeu, tão bem descrita por Camilo Castelo Branco e tão pouco lida pelos estudantes brasileiros, ao contrário de suas outras obras ${ }^{39}$.

\footnotetext{
${ }^{33}$ Oliveira, 1943 apud Novinsky, 1972, p. 106.

${ }^{34}$ Novinsky, 1972, p. 106.

35 A.J. Saraiva, 1956 apud Novinsky, 1972.

${ }^{36}$ Netanyahu, 1966 apud Novinsky, 1972.

${ }^{37}$ Karady, 1991.

${ }^{38}$ Novinsky, 1972

${ }^{39}$ Castelo Branco, 1970. Clássico da literatura portuguesa, Camilo é leitura obrigatória no
}

\section{A época contemporânea}

No fim do século XIX mudou o processo imigratório em geral, inclusive o judaico. Em número reduzido, se comparado a algumas outras nacionalidades, os judeus provêm sobretudo da Europa Oriental (ashkenazim) onde tinham vivido por séculos. Houve também uma leva imigratória proveniente do Norte da África, especialmente do Marrocos e da cidade livre de Tânger (sefardim). Na Europa Oriental tinham vivido por séculos antes mesmo da constituição de Estados nacionais como a Romênia, Polônia, Ucrânia, Rússia e Lituânia. Viveram umas histórias marcadas por alterações políticas, guerras, mudanças nas esferas de poder. Qualquer que tosse o grupo vencedor, eram mantidos numa condição subalterna, sujeitos a expulsão e a altos pagamentos coletivos pelo direito de moradia.

Durante todo o período czarista - que dominou a Rússia, a Polônia e a Romênia - os judeus foram obrigados a viver numa "área de residência", impedidos de possuir ou arrendar terras, excluídos das corporações de ofício e do trabalho em inúmeras atividades. Não tinham o direito de circular. Sofriam ataques a suas Moradias e pequenas oficinas, eram alvo permanente de violências físicas e mesmo assassinatos, seus bens eram roubados, as mulheres violadas. A polícia observava de longe estas agressões. E não foram raros os casos de serem açoitados pelas autoridades ${ }^{40}$.

Em nenhum país reivindicaram autonomia territorial ${ }^{41}$ mas buscaram alcançar igualdade política, cidadania, liberdade religiosa e respeito aos valores culturais. Estas demandas foram interpretadas como um inaceitável direito à diferença e serviram para que, freqüentemente, fossem considerados hóspedes indesejáveis.

Condições semelhantes foram vividas em países do Norte da África e

secundário. No entanto seus dois volumes de $O$ judeu jamais são sequer mencionados para os estudantes.

${ }^{40}$ R. Ertel, 1986. H. Minzeles, 1995. Abrantsky et alii 1987. Plasseraud e Minzelles, 1996.

${ }^{41}$ Karady, 1991, p.161. 
do Oriente. Em todos eles a maioria cios judeus ocupava posições subalternas, a exceção ficava com uma minoria que tinha fortuna ou estava próxima ao poder ${ }^{42}$. Mesmo estes foram subjugados e perseguidos em muitos períodos da História pela inquisição, nazismo, e stalinismo.

Face a todas as privações, violências físicas e perseguições, uma das soluções era imigrar.

\section{A história vivida}

Existe atualmente no Brasil unia comunidade judaica articulada. Diferentemente de alguns processos imigratórios em que as relações étnicas se dissolveram cora o tempo e o contato com outras culturas, a judaica tende a restaurar-se nas sociedades em que se insere.

A questão da transmissão histórica tem como fundo a mudança ou a manutenção da identidade étnica. Barth mostra que para analisar a mudança da identidade étnica se deve procurar os processos que limitam a reprodução dos grupos étnicos ${ }^{43}$. A validade desta teoria permite utilizá-la justamente para o oposto, isto é, para a análise dos grupos sociais que mantêm a identidade social ${ }^{44}$ embora mudem os contextos sociopolíticos.

\footnotetext{
${ }^{42}$ L. Poliakov, 1979, p. 176

${ }^{43}$ Barth, 1994, p. 11.

${ }^{44}$ Ao descrever os passos para a análise, diz Barth que se eleve considerar a: "identidade étnica como um aspecto ela organização social atais elo que unia expressão nebulosa da culatra: sendo patentemente uma questão de grupos sociais ela é um aspecto da organização social da diferença cultural [...]" - isto significa "focalizar as fronteiras e os processos de recrutamento e não o estoque cultural que as fronteiras incluem [...] "mais ao focalizar estes processos de manutenção da fronteira se verifica que os grupos étnicos e suas características são produzidos sob interações particulares en1 circunstâncias históricas, econômicas e políticas: eles (os processos) são altamente situacionais e não primordiais - "sendo uma questão de identidade, pertencer a um grupo étnico depende de ser inscrito ou se autoinscreve". A etnicidade só vai late tinta diferença organizacional se os indivíduos a adotarem ou forem constrangidos por ela, agirem sobre ela ou a experimentarem. [...] as diferenças culturais que marcam a etnia são aquelas que as pessoas usam e não as que os analistas escolhem e supõem que a marcam". Barth, 1994, p. 12. Como ele diz "as pessoas jogam o mesmo jogo. Barth, 1994, p. 12 apud Barth, 1969, p. 15.
}

Para entender a reprodução da cultura o que se deve procurar são "os processos que sustentam as descontinuidades relativas neste fluxo e assim provêm uma base para a identidade étnica. Isto leva aos seguintes passos: 1) observar a variação cultural na população total e plural; 2) identificar nela os processos que geram e destacam descontinuidades culturais maiores. A socialização na família não pode mais - certamente não na sociedade ocidental moderna - ser considerada como a fonte de todo o conhecimento, habilidades e valores, ou a que provê a única base experimental na qual se forja a identidade ${ }^{, 45}$.

Este procedimento é inspirador mesmo em circunstâncias nas quais não pode ser inteiramente aplicado devido à diversidade e amplitude da sociedade global. É frutífero, neste caso, adotar um procedimento de "microescala de observação" pois, concordando com Revel, os fenômenos globais permitem uma outra leitura se os encaramos pelas estratégias que os indivíduos criam e pelas biografias de famílias ${ }^{46}$.

O procedimento que adotamos insere-se parcialmente na microescala ele observação, mas ampliamos o contexto para obter um conjunto que permitisse apreender diferenças e fazer comparações.

O resultado das cerca de 100 histórias de vida coletadas sugere unia trajetória genérica seguida pelos imigrantes judeus no território brasileiro que permite a seguinte descrição: chegando a um porto (Santos, Rio de Janeiro, Recife), os judeus procuravam seus conterrâneos, judeus de mesma região de origem. Após alguns dias de reconhecimento das condições do local, procuravam rapidamente um trabalho. Poucos ficavam nas capitais, iam para o interior dos estados e quando podiam fixavam-se numa pequena cidade. Mantinham contato constante coma capital seja por razões de trabalho ou por relações sociais e religiosas. Os solteiros iam buscar uma esposa na Europa ou na África do Norte, mandavam uma carta de chamada ou casavam-se dentro da comunidade com grande freqüência.

Depois de alguns anos, quando a situação econômica melhorava e os filhos começavam a crescer, mudavam-se para a capital do respectivo

\footnotetext{
${ }^{45}$ Idem, p. 15.

${ }^{46}$ Jacques Revel, 1996, p.12.
} 
estado e, como a maioria dos brasileiros, posteriormente migravam para São Paulo, onde os encontramos.

São Paulo concentra cerca ele 100 mil judeus, de tini total ele 150 mil existentes no Brasil ${ }^{47}$.

A principal causa apontada como determinante para a migração interna foram os filhos: dar educação mais elevada, evitar a divisão da família quando eles tinham ele cursar ensino universitário e permitir aos filhos "ficar mais perto" de outros judeus. Estava aí subentendido ter uma socialização junto à comunidade judaica e facilitar casamentos endogâmicos.

Ao estudar os judeus ele São Paulo acaba-se recompondo todo o processo de imigração elos judeus para e dentro do Brasil.

\section{A linhagem judaica amazonense}

\section{Os Benchimol}

Entre as primeiras referências à presença judaica no século XIX estão os judeus originários do Norte da África (Marrocos francês, árabe, espanhol e da cidade livre de Tânger) onde havia crise econômica e perseguição por parte de alguns sultões. Imigraram para os estados do Amazonas e do Pará ainda antes da grande exploração da borracha. Testemunham esta presença as sepulturas judaicas de Soledad, cemitério de Belém (Pará) e as sinagogas Shaar Ashamaim e Essel Abraham, fundadas naquela cidade entre $1826 \mathrm{e}$ $1828^{48}$. Belém e Manaus foram as portas de entrada para judeus que se instalaram em cidadezinhas do interior do Pará e do Amazonas. Há referências à presença de famílias judaicas, no século XIX e nas primeiras décadas do século XX, às beiras de vários rios entre os quais o Tapajós,

\footnotetext{
${ }^{47}$ Jewish Communities of the World. Institute of World Jewish Congress. 1996. Esta instituição informa que há 130 mil judeus no Brasil.

${ }^{48}$ S. Benchimol, 1994
}

Abunã e nas seguintes localidades ${ }^{49}$.

\begin{tabular}{|c|c|}
\hline \multicolumn{2}{|c|}{ Quadro 2} \\
\hline $\begin{array}{l}\text { Famílias judaic: } \\
\text { décadas do } \mathrm{s}\end{array}$ & $\begin{array}{l}\text { ulo XIX e nas primeiras } \\
\text { na região amazônica }\end{array}$ \\
\hline Localidade & Família \\
\hline Alenquer & $\begin{array}{l}\text { DAHAN, BENUIGUI, } \\
\text { ATHIAS E FINAS }\end{array}$ \\
\hline $\begin{array}{l}\text { Boim, Aveiros e Itaituba } \\
\text { Cametá }\end{array}$ & $\begin{array}{l}\text { BENCHIMOL, BENTES } \\
\text { ABSÁ, LARRAT, AMZALACK }\end{array}$ \\
\hline
\end{tabular}

\begin{tabular}{|ll|}
\hline Localidade & Família \\
\hline Coari & PINTO \\
Gurupá & ABENATHARE, SICSU e \\
& AZULAY \\
Humaitá & LEVY \\
Itacoatiara & PERES e EZAGUI \\
Macapá & ZAGURY \\
Maués & BECASSIS e LEVY \\
Melaşo & SERFATY \\
Óbidos & CHOCRON, AMOY e \\
& ELMESCANY \\
Parintins & ASSAYAG e ZAGURY \\
Portel & BENZECRY \\
Santarém & SERRUYA e CAGY \\
Sena Madureira & LAREDO e ABTIBOI \\
Tefé & SIQUEIRAS \\
& \\
Fontc: Bcnchimol 1994 p. 2 c 4. & \\
\hline
\end{tabular}

Por volta de 1850 existia uma comunidade judaica em Santarém e

\footnotetext{
${ }^{49}$ Idem, p. 2 e 4.
} 
Itaiutuba, à beira do rio Tapajós, que deixou conto traço, mais unia vez, as sepulturas dos "judeus pioneiros do ciclo da borracha". Teriam emigrado há décadas de Tetuan, Ceuta, Casablanca, Fez, Rabat, Marrakech, ${ }^{50}$ empurrados pela crise econômica do Marrocos e pela perseguição de vários sultões. Por outro lado os governos do Amazonas e Pará facilitavam a vinda de imigrantes. Falavam o português e o espanhol antigos, do século XVI, e o haquitia, mistura destas mais o árabe-marroquino ${ }^{51}$.

Era tão frequiente a vinda de imigrantes para a Amazônia que os navios da Companhia Italiana Ligure Brasiliana "fazia(m) a linha Gênova, Marselha, Tânger, Lisboa, Belém, e Manaus... ${ }^{52}$

Outra leva que aporta na região amazônica, no século XIX, é de judeus vindos da França. Uma versão explica que quando a França foi derrotada pela Alemanha em 1870, rejeitando tornarem-se alemães, muitos judeus alsacianos ${ }^{53}$ foram para Paris, para o Sul da França e alguns deles vieram para o Brasil. Discordando daquela explicação, Raphael, VidalNacquer e outros indicam que os judeus alsacianos eram discriminados pela maioria católica e protestante local e foram para outras partes da França ou imigraram para tornarem-se "iguais". Em São Paulo, instalaram atividades relacionadas ao comércio de penhores, no centro da cidade. Outros foram para Manaus, onde se tornam importadores de bens franceses como relógios, artefatos para casa, instrumentos dentários e ladrilhos e vidros para o Teatro Amazonas, construído em pleno auge da exportação da borracha e que era etapa obrigatória nas turnês dos grandes artistas internacionais no fim do século XIX.

Os judeus da África do Norte foram trabalhar no comércio dominado pelas casas aviadoras. Estas vendiam a crédito, ao seringalista, desde

\footnotetext{
${ }^{50}$ Idem. p. 02

${ }^{51}$ Idem, p. 55. É preciso lembrar também que os judeus do Norte da África tinham emigado de Portugal e Espanha na época da Inquisição (1492 e 1500) e guardavam o português e o espanhol.

${ }^{52}$ Idem, p. 55.

${ }^{53}$ M. Fournier, 1994, mostra que na Alsácia e na Lorena os judeus, conto minoria, entre católicos e protestantes, viveram períodos muito difíceis. Foram objeto de violências e extorsões e no imaginário popular eram associados a ladrões, p.33 apud Raphael Weyl, p. 408-409.

utensílios para extração da borracha, roupas, alimentos, remédios, em troca da borracha; os seringueiros ficavam sempre endividados com este mecanismo. Entre os judeus imigrantes muitos trabalhavam como empregados destes aviadores. Mas alguns tentaram romper o monopólio das grandes empresas. Sírios, libaneses e judeus instalaram pequenos negócios e foram procurar o seringueiro diretamente nas margens dos igarapés, às escondidas, para vender mercadorias e comprar borracha. "Era então um negócio clandestino (sic) que implicava grandes riscos. Os seringalistas e aviadores os perseguiam, pois o monopólio da venda de mercadorias e compra de borracha aos seringueiros lhes pertencia. Lesados (sic), agiam drasticamente, punindo com severidade o regatão" ${ }^{, 54}$. Como se vê a análise exposta acima está permeada pela ideologia monopolista das grandes casas aviadoras.

Entre as primeiras levas de imigrantes que chegaram a Santarém e no Tapajós, por volta de 1850, vieram Israel Isaac Benchimol e seu irmão Abraham Isaac Benchimol, originários de Tânger, Marrocos... ${ }^{55}$ A trajetória vivida por Israel e seu filho Isaac é muito semelhante a de outros judeus seus contemporâneos na Amazônia.

Abraham morreu cedo.

Israel teve um filho, Isaac, em 1888, em Aveiros, no Pará, e morreu quando o menino tinha 7 meses.

Isaac foi criado pela avó Thomasia, judia-marroquina, que o levou a Tânger quando tinha 8 anos "para dar-lhe uma educação religiosa e profissional" ${ }^{156}$.Fez o primário na Aliança Israelita Universal como seu pai o fizera.

A Aliança Israelita Universal é uma instituição de origem francesa, criada por volta de 1800 para dar apoio aos judeus perseguidos em outros países, desprovidos de cidadania e sem recursos econômicos. Ela dava educação e formação para o trabalho. Com sede em Paris esta instituição inspirou-se na concessão de cidadania aos judeus (1791) dois anos após a Revolução Francesa, para apoiar as demais comunidades judaicas sujeitas a pogroms e a selvagens perseguições como as da Romênia, Rússia, Polônia e

\footnotetext{
${ }^{54}$ Prado e Capellato, p. 94. Lamentavelmente as autoras não foram felizes na forma com que descreveram a situação deixando dúvidas ao leitor: por que dizer que as grandes casas aviadoras foram lesadas?

${ }_{55}^{55}$ Benchimol, 1994, p. 62.

${ }^{56}$ Idem, p.62
} 
outros países.

$\mathrm{Na}$ Aliança Israelita Universal Isaac fez o primário, “aprendeu hebraico e foi introduzido no estudo da Torá. Lá ficou durante 5 anos quando sua avó resolveu voltar, em 1903, para Belém do Pará, tendo antes cumprido o dever religioso do Bar-Mitzvá numa sinagoga de Tânger" ${ }^{, 57}$.

Chegando a Belém começou a trabalhar imediatamente como balconista e vendedor e à noite estudava contabilidade para ter uma profissão.

Em Belém e Manaus as grandes casas exportadoras e aviadoras pertenciam aos ingleses, alemães, franceses e portugueses que controlavam o comércio da borracha e demais produtos da região. Quem quisesse se iniciar nos negócios tinha de ir para o interior, mas antes precisava obter crédito junto às casas aviadoras.

Não dispondo de condições econômicas Isaac, aos 21 anos (1909), vai trabalhar no Acre, no rio Antimary como balconista de um barracão num seringal. Lá ficou vários anos aprendendo. Coai suas economias começou a trabalhar, como seu pai o fizera, "no ramo de regarão comerciante fluvial ambulante" - comprando e vendendo mercadorias e gêneros para os seringais do rio Tapajós e Baixo Amazonas ${ }^{58}$.

Tornou-se profundo conhecedor da região e foi servir como guia ao Capitão Rondon, recebendo o título de Capitão da Guarda Nacional. Casou-se com uma prima e, enviuvando, casou-se novamente com unia mulher judia. Nina Siqueira (D. Lili), filha de Raphael Siqueira, comandante de uma embarcação cuja companhia tinha sede cm Tefé, no rio Solimóes.

Teve 8 filhos dos quais três homens. Vivia nos seringais perto da Bolívia, junto ao Rio Abunã. Levava os filhos para o brith-milah (circuncisão) em Porto Velho "onde havia uma pequena comunidade judaica" que trabalhava seja nos seringais seja na construção da estrada de ferro Madeira-Mamoré. ${ }^{59}$

Seus negócios acompanharam o auge e a crise da borracha; acabou falindo. Sua mulher, D. Lili, "trabalhando dia e noite, numa velha máquina de costura Singer, fabricando e costurando blusões de

\footnotetext{
${ }^{57}$ Idem, p.63.

${ }^{58}$ Idem, p.62 e 64

${ }^{59} \mathrm{Idem}$, p.65, 66.
}

azulão, brim ou sacos usados de farinha de trigo, para vender aos seringueiros e aviadores, e vestidos de chita e algodão para as mulheres do seringal", consegue comprar as passagens numa gaiola e manda os filhos homens para "a casa de sua mãe portuguesa-judia, D. Lucila Siqueira, em Belém do Pará" ${ }^{60}$.Deviam estudar e fazer o BarMitzvá.

Após perder tudo com a crise de 29 , Isaac só vai conseguir um emprego como guarda-livros em Manaus alguns anos depois.

Paga suas dívidas mesmo prescritas e com isso a vida familiar se tornou extremamente dura. Não podiam tomar um bonde ou ir ao cinema. Na sexta-feira e rio sábado "íamos todos à sinagoga improvisada na Av. Getúlio Vargas, para fazer as orações de arbith e tefilah (sic) c (também) às cerimônias religiosas de Pessah, Sucot, Shabuoth, Rosh-Hashanah, Yom Kipur, Purim e Hanuká. (Cumpria) os deveres religiosos juntamente com todos os seus filhos. ${ }^{61}$

Os filhos fizeram universidade e alguns continuam na região amazônica.

Antes de morrer Isaac expressou o desejo de ter um enterro judaico - com uma mortalha. Pediu ao Rabino para ler os Tehelim (Salinos de Davi) e pediu para que todos os filhos rezassem com ele parte da orarão. Shemá Israel:

"Ouve, Israel, Adonai é nosso Deus, Adonai é um só..." 62

Recomendou que ficassem de luto, sentados no chão, por três dias após sua morte. Ou seja, fez pedidos que cumpriam parcialmente o ritual judaico pois, como disse, os filhos tinham de trabalhar.

A história de Isaac é paradigmática. No meio dos seringais, afastado por longos períodos da comunidade judaica, isolado à beira dos rios, vivendo num meio católico permeado por crenças indígenas e afrobrasileiras $^{63}$, sem ter uma sinagoga, Isaac e outros judeus tão dispersos quanto ele restauraram o judaísmo e a prática ritual possível. Mantinham alguns preceitos com atos que marcavam etapas do ciclo de vida como o nascimento, circuncisão, Bar-Mitzvá, o sepultamento e também o

\footnotetext{
${ }^{60}$ Idem, p. 65.

${ }^{61}$ Idem, p. 67.

${ }^{6}$ Idem, p. 70.

${ }^{63}$ Observe-se que tão estou afirmando que ele ou os outros tenham ficado alheios as influências das outras religiões. Ao contrário, em várias histórias de vida há unta clara adoção de outras práticas e crenças.
} 
casamento endogâmico. O saber aprendido na infância era reproduzido, partilhado, expandido. O elo religioso e cultural da comunidade de origem não era esquecido nem abandonado. Não se rompeu. Posteriormente, quando retornou ao centro urbano, ele se reagrupou a outros judeus e participou da construção restauração de uma comunidade judaica em Manaus.

Isaac Benchimol tinha uma auto-imagem de sua posição social: cidadão brasileiro, amazonense, judeu. Esta complexa síntese se revela na carta que deixou para ser lida após sua morte ocorrida em 24/12/1971:

À minha querida e adorada esposa Lili e aos meus inestimáveis filhos e netos:

Ao partir deste mundo sinto-me imensamente feliz, por ter deixado, na Terra, uma geração de homens e mulheres que honram $o$ Amazonas, o Brasil e o Mundo, ${ }^{64}$ após ter cumprido a minha missão na Terra com honestidade e hombridade. Fiz tudo que foi possível fazer em favor de nossa comunidade, deixando como Presidente do Comitê Israelita do Amazonas um valioso patrimônio para ela, ajudado pelos meus filhos Israel, Samuel e Saul e por toda a comunidade judaica desta cidade.

Desejo que todos os meus filhos e netos sigam todas as nossas tradições judaicas e saibam honrar o nome de nossa família. Só desejo que se lembrem das minhas NAHALOT e digam um KADISH todos os anos ${ }^{65}$.

Benchimol assume-se judeu, amazonense e brasileiro. Sua identidade é unia soma destas dimensões. É um brasileiro da região amazônica. Conto os demais brasileiros sua identidade passa pelo regional.

Mas ele soma mais uma dimensão, a identidade judaica, que ele define à sua maneira. Amplia sua atuação judaica assim que retorna a um meio onde existem outros judeus. Consagra-se ao trabalho de instalar e reestruturar uma comunidade. A sinagoga, a escola, a ajuda mútua, o cemitério. Ao invés de se diluir, sua ação se soma a de outros semelhantes para sedimentar para o futuro esta antiga e restaurada comunidade judaica.

\footnotetext{
${ }^{64} \mathrm{O}$ destaque não consta do original.
}

${ }^{65}$ Idem, p. 70.
Comandante de embarcação, comerciante fluvial ambulante, seringueiro, regarão, trabalhador braçal em estrada de ferro, escriturário, ou comerciante bem-sucedido, todas foram profissões desempenhadas na região amazônica pelos judeus das duas primeiras gerações, no século XIX e começo do $\mathrm{XX}^{66}$ Como todos os demais brasileiros da região trabalharam, construíram família, nasceram e morreram na Amazônia ou migraram para outras partes do Brasil. Este grupo diferenciou-se ao constituir um dos ramos clã primeira geração de judeus do Brasil contemporâneo.

A transmissão inicial da condição judaica se deu através da família. É por ela que as crianças ficam sabendo que são judias. Outras instituições concorrem para tal formação como a "escola judaica informal", o "Professor", aquela pessoa que sabia o hebraico, a leitura ela Torá e ensinava ao adolescente. A história de Isaac Athias revela o papel da família e as formas de preservação clã cultura e da religião judaica no Amazonas e posteriormente sua expansão pelo resto do Brasil.

\section{Isaac Athias: Rosh Hashaná sobre palafitas}

A história de Isaac Athias revela como o judaísmo essencialmente urbano sobrevive em região de floresta, de vida quase isolada entre rios e igarapés.

Eu sou descendente de judeus marroquinos; meu pai é de Rabad e minha mãe de Arzilia, no Marrocos. Eles estão no Brasil desde 1880, vieram "fazer a América", como se dizia. Não era uma imigração forçada, as pessoas vinham com a idéia de adquirir alguns recursos e voltar, o que não aconteceu pois acabaram ficando aqui, se enraizando.

Meus pais se casaram no Brasil e somos nove irmãos: Maluf, Alegria. Nina, Isaac, Moisés, Jacob, Nori e José. Estamos na $4^{\mathrm{a}}$ geração e a maioria ficou em Belém do Pará.

Nasci em 1908, em Belém, nós morávamos no interior do Pará, em

\footnotetext{
${ }^{66}$ B. Levy, Raphael Benoliel, Isaac Benayon Sabbá, Isaac Jacob Benzecry e Isaac Israel
} Benchimol. Benchimol, 1994. 
Breves. Fiz meu curso primário no interior, com viagens prolongadas. [...] as escolas eram distantes e se ia remando em pequenas embarcações até chegar à escola [...] Meu pai era seringalista, isto é, tinha um barracão, comprava as pranchas de borracha, e os seringueiros eram aviados por ele. Depois a borracha ia para o aviador que a exportava para a Inglaterra.

Nos morávamos no interior e só havia ligação com Belém a cada 15 dias, quando passava a gaiola que era uma pequena embarcação. De Breves a Belém levava umas 36 horas.

As condições de vida de Athias assemelham-se às dos seringueiros, mas diferenciam-se com relação à importância atribuída à educação formal: quando, por razões político-econômicas, a escola foi extinta, seu pai cedeu parte de própria moradia para nela ser instalada uma escola pública.

O barracão de meu pai se chamava 'Livramento do Ituquara', era nina pequena terra toda cercada por igarapés, eram ilhotas isoladas. No interior era assim, morávamos na margem dos rios, em casa com estacas por causa da maré.

Durante as festas religiosas, como a nossa casa era muito grande e o meu pai era religioso, reuniam-se lá. Vinham de diversas localidades, de outros municípios como Apuã, Anajás [...] vinham remando três ou quatro dias para poderem fazer as festas em conjunto.

Por exemplo, vinham para o Rosh Hashaná e ficavam ali mais ou menos 70,80 pessoas no barracão. Isso era fácil pois não tinha cama, se dormia em redes; os salões eram grandes. Ficavam umas 10 ou 20 redes espalhadas em cada sala. Eu tenho boas lembranças dessas festas.

É tão óbvio para Athias que as festas eram judaicas que ele nem o menciona. Refere-se apenas a "festas religiosas". Viviam como os amazonenses em casas de palafita, o cotidiano era o rio e a floresta. Mas se reuniam para as "grandes festas": o Ano Novo Judaico (o Rosh Hashaná), e o Grande jejum (o Yom Kipur). Várias gerações se encontravam, transmitiase a tradição e o ensinamento.

Não tínhamos a Torá, o rolo dos livros sagrados, tínhamos apenas o livro de preces. Não tinha rabino. Meu pai é que servia de "hazam" (cantor litúrgico).

As rezas eram em hebraico, mas hebraico literário! Nosso ritual era sefaradim, que é diferente do ashkenazim seja para ler o hebraico ou na comemoração de Pessach (Páscoa).

Portanto, a distância não significava isolamento nem esquecimento de raízes aprendidas em lugares distantes e em outras etapas da vida infância, adolescência, ou na idade madura. $\mathrm{O}$ isolamento era relativo, os contatos constantes, porém, com longos períodos de afastamento. Obedecendo a um calendário religioso, à beira dos rios, dos igarapés, improvisava-se uma casa de oração e se reuniam os judeus das "proximidades" - o tempo se media em dias de barco. O calendário judaico era o mesmo que em qualquer parte do mundo: comemorava-se o dia $1^{\circ}$ de Tishrei (Dia de Rosh Hashaná, início do Ano Novo) e o 102 dia de Tishrei (Dia do Yom Kipur ou Dia do Perdão). ${ }^{67}$

O modo de conviver era o amazônico - a rede, o alimento vindo do rio, a roupa. Nesta data era mais importante estar junto, orar coletivamente, pedir "perdão a Deus" pelos pecados cometidos e ser "inscrito no Livro da Vida" para o ano vindouro conforme mandava a tradição religiosa.

Construía-se na família a socialização judaica das crianças e os tios da rede comunitária do interior da Amazônia

Outras cerimônias traziam um certo formalismo à educação judaica dos meninos por ocasião da maioridade religiosa, o Bar-Mitzvá. É a figura do (sempre) pobre ${ }^{68}$ professor leigo do "steitel europeu" ou das comunidades judaicas norte-africanas que reaparecia no Brasil para ensinar as rezas em hebraico e os procedimentos religiosos. Conta Athias:

A parte religiosa da minha educação foi dada por um dos judeus mais religiosos que conheci, o Sr. Elias Israel. Sua família era rica, empobreceu cone a queda da borracha e ele foi ser professor de hebraico. Morava cm Belém e também trabalhava como ambulante. Ele passou a vida comendo casher (alimento preparado conforme o ritual judaico) que a mulher preparava e tinha que durar de 30 a 40 dias. Conservavam com gordura.

A senhora dele montou uma pensão para hospedar os meninos judeus que vinham do interior estudar hebraico com ele. Vim com uns 12

\footnotetext{
${ }^{67}$ Calendrier Annuaire 5757 (1996-97). Société Paris 12 ème.

68 Embora respeitado, o professor sempre teve uma remuneração aquém de suas necessidades e economicamente se equiparava aos indivíduos pobres.
} 
anos me preparar para por os "tfilim" (filactérios) e fazer a BarMitzvá. Ficávamos de 3 a 4 meses hospedados na casa do Professor. Era muito respeitado pela comunidade apesar da pobreza e de sua vida modesta.

Athias conta que para continuar a tradição religiosa da casa paterna foi aprender o hebraico, ler a Torá e se preparar para o ritual de sua maioridade judaica aos 13 anos. Para isto teve de deixar a casa paterna. Mas como pagar tudo isto?

Meu pai perdeu tudo cone a guerra de 1914. Porque o principal produto era a borracha [...] Mais ou menos nesta época minha mãe foi visitar a minha avó em Belém, estava muito necessitada e a minha avó lhe deu 50 mil-réis, me parece[...] Mas ela queria aprender qualquer "indústria", não sabia o que é pedir. Então, passando numa rua, viu uma placa de um professor e entrou.

- Mas o que a Sra. quer aprender?

- Eu não sei...

- Onde é que a Sra. mora? O que tem lá?

- Moro no interior, lá tem muitos roçados, tem aquela queima que forma cinzas, tem frutas oleaginosas...

- Então a Sra. vai aprender a fazer sabão, porque a Sra. tem iodos os elementos locais, só leva da capital a soda cáustica.

A mulher entra com seu trabalho para reorganizar a vida econômica da família (lembremos D. Lili costurando e vendendo blusões e vestidos de chita, a esposa do Professor que mantinha unia pensão para os meninos...)

Então ela comprou um tambor de soda cáustica, e começou a fazer sabão. Quando se queimava o roçado no interior, juntávamos a cinza para tirar a lixívia para fazer o sabão; e das frutas oleaginosas, o sebo e o óleo, que eram a base para o sabão. Nós colhíamos estas frutas quando íamos para a escola. Depois, quando aumentou a venda comprávamos dos caboclos. Primeiro se vazia o sabão cameçá, pastoso. Depois foi aperfeiçoando. Meu irmão Abrão foi a Belém e uma fábrica aprendeu a fabricar sabão e aí junto com tainha mão. Montou uma pequena indústria. E desta indústria então é que saiu a possibilidade de irmos a Belém. Porque então já tínhamos condições de pagar cinco mil-réis por mês de hospedagem na casa do Professor.

A mãe reergue as finanças da família. E assim consegue alimentar, educar e dar formação judaica aos filhos.

Nas duras condições regionais, a partir da família, das espaçadas mas constantes relações entre os de mesma origem étnica, do cumprimento de um calendário religioso e das regras que marcam o ciclo de vicia, restauram-se as bases religiosas, culturais e históricas. É um reatar cultural e a restauração de uma nova comunidade judaica.

A religião judaica tem um forte componente coletivo. O indivíduo pode fazer suas preces diárias sozinho, mas para a maioria dos rituais que marcam o ciclo de vida (circuncisão, enterro, luto, rezas) é necessário reunir 10 homens, um "miniam". Não creio que este procedimento religioso explique inteiramente a constituição de comunidades judaicas como a amazônica. Estas têm um caráter laico importante e podem independer de práticas religiosas para se constituírem. No norte brasileiro a religião judaica provocou a organização de unia rede comunitária e reinstitucionalizou antigas práticas.

Os historiantes ${ }^{69}$ foram fundadores ou continuadores das associações que instituíram as bases da comunidade judaica atual da região amazonense. Quando alguns se mudaram para São Paulo continuaram a mesma prática.

\section{Conclusão preliminar}

Analisando a literatura sobre o Brasil até aproximadamente a década de 50, mostra Garcia ${ }^{70}$ que se pensava o país em amplas divisões: Norte, Sul, Centro. Fernando de Azevedo foi um dos pioneiros a perceber e nomear o Oeste apreendendo unia região socialmente definida. Destacar o Nordeste da região Norte e individualizá-lo foi fruto de unia "invenção" de autores como Celso Furtado, que revelou como a generalização "norte" escondia o vínculo identitário da população "nordestina"71.

\footnotetext{
${ }^{69}$ M.I. Pereira de Queiroz, 1988

${ }^{70}$ Garcia Jr., 1996.

${ }^{71}$ Idem.
} 
Entender este espaço social resultava de se desmembrar a Região Norte distinguindo nela a Região Nordeste. Não se trata de uma designação artificial, mas sim do reconhecimento de distinções existentes em todos os planos naquela vastíssima região brasileira.

A questão espacial é um aspecto exterior da identidade vinculada à região. Constitui um dos elementos da brasilidade. O indivíduo se sente brasileiro, mas brasileiro de unia dada região.

Esta intermediação regional da brasilidade aparece nos relatos de vida e nas trajetórias de imigrantes judeus e de seus filhos judeus brasileiros.

O Brasil traz também uma outra dimensão à restauração étnica. Comparando os estudos sobre a comunidade judaica feitos na Europa com este que faço no Brasil verifico que todos os estudos europeus relatam uma história que tem momentos de ruptura, fases em que a presença judaica é "liquidada". A $2^{\text {a }}$ Guerra Mundial, o shoa, o governo Vichy, o stalinismo, o anti-semitismo na Europa Oriental, marcaram esta história com o vetor da destruição de um grupo social que se integrava ou pensava se integrar varias gerações.

Na América do Sul distinguem-se dois percursos. Países como a Argentina $^{72}$, Paraguai, Bolívia e Chile, com um movimento anti-semita claro - pontuado por atentados terroristas recorrentes - que abrigaram nazistas criminosos de guerra com a conivência governamental e países como o Brasil em que estes fatos ocorreram esporadicamente sobretudo na ditadura getulista. ${ }^{73}$ Em consequiência, a visão que se tem da comunidade judaica hoje, do ponto de vista sociológico, é a de um processo de integração social. Face à experiência histórica internacional esta integração é feita cautelosamente. A comunidade não se desfez na sociedade global. Ao mesmo tempo em que se incorpora inteiramente à sociedade brasileira ela reconverte suas instituições, se resguarda face a manifestações antisemitas como as já vividas secularmente em outras partes do mundo.
A comunidade judaica tem fronteiras flexíveis, porosas. Acompanha a dinâmica da sociedade brasileira e é articulada a ela. Ao mesmo tempo define um corpo de instituições distintas dentro da sociedade global. Restaura suas raízes na pluralidade da sociedade brasileira.

\footnotetext{
${ }^{72}$ R. Weisbrot, 1979

${ }^{73}$ E.A. Blay, 1989.
} 


\section{Bibliografia}

ABRAMSKY, CHIMEN et alii (ed). The Jews in Poland. Oxford-New York: Basil Blackwell, 1987.

BARTH, Fredrik. "Enduring and Emerging Issues in the Analysis on Ethnicity". In: VERMEULEM, H. e GOVERS, C. The Anthropology of Ethnicity - Beyond Ethnic Groups and Boundaries. Het Spinhuis. p. 12-31, 1994.

BELLER, Illex. De mon shtetl à Paris. Editions du Scribe, 1991.

BENCHIMOL, Samuel. Judeus do ciclo da borracha. I Encontro Brasileiro de Estudos Judaicos da Universidade do Estado do Rio de Janeiro, 24-25 Outubro 1994. Universidade do Amazonas, Manaus, 1994. 75 p. xerox

BEREZIN, Rifka. Caminhos do povo judeu, vol. 3, Vaad Hachinuch-19756735. São Paulo.

BERTAUX, Daniel. Biography and Society. London: Sage, 1981.

BLAY, Eva Alterman. Eu não tenho onde morar: estudo sobre vilas operárias em São Paulo. São Paulo: Nobel, 1985.

. "Dormitórios e vilas operárias: o trabalhador no espaço urbano" In: Valadares, L. P (org). Habitação em questão. Rio de Janeiro, 1987.

"Inquisição, inquisições: aspectos da participação dos judeus na vida sociopolítica brasileira nos anos 30.” Tempo Social, n.1 (1), 105-130, 1989.

"As duas memórias: pequena história da imigração judaica". Shalom, Ano XIX, agosto de 1984, n. 223, p.4-11.

Judeus em São Paulo: O Encontro de Diferentes Trajetórias. Vídeo feito em colaboração com a RTC Radio e Televisão Cultura.
CARDOSO, Fernando Henrique. "Dos governos militares a PrudenteCampos Sales”. In: FAUSTO, B. (ed.) História geral da civilização brasileira: o Brasil republicano. Vol. 8. Ed. Difel/Difusão Editorial S.A., 1977.

CASTELO BRANCO, Camilo. O judeu. Lisboa: Parceria A.M. Pereira Ltda., 1970.

ELAZAR, Daniel J. “The Reconstitution of Jewish Communities. In “The Post-War Period". The Jewish Journal of Sociology, 11 (2) dez. 1969. pp. 187-226.

ERTEL, Rachel. Le shtetl: La bourgade juive. Paris: Payot, 1986.

FURTADO Celso. Formação econômica do Brasil. São Paulo: Ed. Nacional, 1969.

GARCIA Jr. Afranio. "L'Invention du Nordeste Brésilien. L'origine international des identités regionaux". Conferência realizada no Institut d'Amérique Latine em 28/3/96.

INSTITUTE of the World Jewish Congress. "Jewish Communities of the World", 1996.

"Jewish Communities of the World". Kesem Kibbutz Saad: Israel, 1996.

KARADY, Victor. La presence juive en Europe Centrale à l'époque contemporaine, invariants et specificités nationales. Cahiers de Varsovic, 22 p. 161-169. Centre de Civilisation Francaise. Editions de l'Université de Varsovie, 1991.

LAFER, Celso. O Judeu em Gil Vicente. São Paulo: Conselho Estadual de Cultura, 1962.

LESTSCHINSKY, Jacob. "Migrações judaicas 1840-1956”. In: RATNER, Henrique (org.) Nos caminhos da diáspora. Centro Brasileiro de Estudos Judaicos. São Paulo. 
MÉRIENNE, Patrick. Petit atlas mondial. Éditions Ouest-France, 1994.

MINCZELES, Henri. Histoire générale du Bund. Un mouvement révolucionnaire juif. Paris: Austral, 1995.

MOULINAS. René. Les Juifs du Pape. Paris: Albin Michel, 1992.

NOVINSKI, Anita. Cristãos-novos na Bahia Ed. Perspectiva e EdUSP, 1972.

PLASSERAUD, Yves \& MINZELLES, H.(ed). Lituanie juive. 1918-1940. Message d'um monde englouti. Paris, 1996.

PETRONE, Maria Tereza Schorer. cap. 111. In: FAUSTO, B. (ed.) História geral da civilização brasileira: o Brasil republicano, tomo III vol. 2. Difel/ Difusão Editorial. pp 93-180, 1978.

PEREIRA DE QUEIROZ, Maria Isaura. "Relatos orais: do indizível ao dizível", pp. 14-43. In: SIMSON, Olga R.M. Experimentos com História de Vida: Itália-Brasil. São Paulo: Ed.Vértice.

POLIAKOV, Leon. De Cristo aos Judeus da Corte. São Paulo: Editora Perspectiva, 1979.

PRADO Jr., Caio. Formação do Brasil contemporâneo. São Paulo: Ed. Brasiliense.

PRADO, Maria Lucia Coelho \& CAPELATO, M.H.R. "A borracha na economia brasileira da Primeira República". O Brasil Republicano, vol. III, p.291 e p. 93-180. Ed.Difel/Difusão Editorial S.A.

RAPHAEL, Freddy e WEYL, Robert. Juifs en Alsace. Toulouse: Privat, 1977.

REVEL, Jacques. Jeux d'échelles. La micro-analyse à l'expérience. Paris: Flautes Études. Gallimard. Le Seuil, 1996.

SAINT MARTIN, M. "Les élites. Formation, reconversiion, internationa- lisation". Colloque de Stocklom, 24-26 setembro 1993. Donald Broady et alii. (ed.) Centre de sociologie de l'éducation et de la cultura. Paris: École des Hautes Études en Sciences sociales, 1995.

SCLIAR, Moacyr. Caminhos da esperança: a presença judaica no Rio Grande do Sul. Porto Alegre: Riocell, 1992.

WEISBROT, Robert. The Jews of Argentina, from the Inquisition to Peron. Philadelphia: The Jewish Publication Society of America, 1979. 


\section{Conversões e casamentos "mistos": a produção de "novos judeus" no Brasil \\ Bila Sorj ${ }^{2}$}

Dentre as inúmeras transformações que o modo de vida dos judeus sofreu sob o impacto da modernidade, destaca-se o crescimento dos casamentos exogâmicos. Tornado, por grande parte da literatura especializada e pelo establishment judaico, como um indicador de indiferença identitária, os casamentos "mistos" ameaçariam a continuidade do povo judeu ${ }^{3}$.

Entretanto este assunto é mais complexo do que parece à primeira vista e não justifica uma correlação simples. Os casamentos mistos cresceram em tamanhas proporções que já se estabeleceram como um padrão matrimonial entre os judeus. Se até em décadas recentes o casamento de um judeu com um cristão tinha geralmente o sentido de favorecer sua aceitação no meio circundante e, em alguns casos, servir de proteção frente ao anti-semitismo, na atualidade apresenta-se como um fato normal da vida familiar dos judeus, apesar de ainda sofrer maiores resistências nas gerações mais velhas e nas famílias religiosas ortodoxas.

Por outro lado, as ideologias através das quais os judeus identificamse cobre um amplo espectro de vivências que variam no tempo e no espaço.

\footnotetext{
${ }^{1}$ Agradeço a gentil colaboração do Rabino Alejandro Lilienthal, da Associação Religiosa Israelita, com a pesquisa e à Keila Grimberg pela competente atuação conto assistente de pesquisa.

${ }^{2}$ Professora de Sociologia - IFCS/UFRJ.

${ }^{3}$ Esse debate tem se realizado sobretudo entre demógrafos, ver Sergio DellaPergola e Uziel O. Schinelz, Demografic Transformation of American Jewry: Marriage and Mixed Marriage in 1980. Calvin Goldscheider, American Jewish Marriages: Erosion or Transformations?, Sergio DellaPergola e Uziel O. Schmeltz, American Jewish Marriages: Transformation and Erosion: a Rejoinder to Calvin Goldscheider em Medding, Peter, Y. (ed), Israel, State and Society. Studies in Contemporary Jewry, Institute of Contemporary Jewry, Oxford University Press, 1939.
}

Se, para um olhar exterior, os judeus são definidos basicamente como membros de um grupo religioso, internamente prevalecem inúmeras modalidades de autopercepção e coesão grupal.

Há mais de cem anos, as identidades cios judeus europeus (continente onde se localizava a maioria absoluta deles) fundavam-se em ideologias concorrentes entre si, visões de mundo e práticas culturais que os dividiam entre religiosos tradicionalistas, liberais e assimilacionistas, além de divisões de natureza geográfica, derivada dos países em que viviam ou provinham, ou de comportamento (alemães, poloneses, lituanos, sefarditas etc.). No início deste século, outras identidades emergem: judeus religiosos versos judeus seculares ou bundistas (judeus seculares poloneses ligados a um socialismo idischista) versus sionistas. Com o estabelecimento do Estado de Israel, em 1945, emerge uma nova distinção entre judeus israelenses e Judeus da diáspora. Cada uma destas divisões apresenta, evidentemente, outras clivagens e nuanças.

Finalmente, no momento atual, chamado por alguns de pósmodernidade, mudanças radicais nos estilos identitários seculares vêm ocorrendo ${ }^{4}$. A identificação com ideologias coerentes e exclusivas vela sendo substituída por um movimento, que, aliás, não ocorre exclusivamente entre judeus, de recuperação e recriação da tradição. Depurados de seus contextos de origem, da carga de emoções e sentimentos que provocaram, das hostilidades e inimizades que instauraram, das vitórias e derrotas que sofreram, estas manifestações aparecem hoje como parte de um passado idealizado. Cultivar ligações com o judaísmo significa, na atualidade, consumir um ou outro produto cultural de um vasto cardápio de bens simbólicos. Estes podem se expressar, por exemplo, na participação em festas e rituais religiosos; no consumo habitual de comida judaica adquirida em delicatessen da moda; na realização de viagens regulares a Israel; no consumo de bens culturais produzidos sobre o Holocausto, como best-

${ }^{4}$ Para uma análise das transformações do judaísmo moderno c sua reconstrução pósmoderna ver Bernardo Sorj, "O judaísmo moderno em perspectiva histórica. Do judaísmo rabínico ao judaísmo pós-moderno". In: Sorj, Bernardo e Grin, Mônica (orgs.) Judaísmo e Modernidade: metamorfoses da tradição messiânica. (Rio de Janeiro: Imago, 1991) e Jonathan Webber, "Modern Jewish Identities" in Webber, Jonathan (org.), Jewish Identities in the New Europe. London, Litman Library of Jewish Civilization, 1994. 
sellers, filmes, exposições, memórias, viagens guiadas aos campos de extermínio; na produção de arquivos, bancos de dados, museus, multimídia sobre a história das comunidades judaicas antes e depois da grande emigração européia moderna etc.

Se, no período moderno, a identidade judaica era moldada em função dos desafios impostos pela emancipação e integração na sociedade circundante - tão bem expresso na angustiante necessidade de encontrar respostas à "questão judaica" —, no momento atual a identidade judaica se alimenta quase que exclusivamente da busca de um sentido subjetivo, pessoal.

Diante disso, os estudos sobre identidade judaica e o impacto dos casamentos mistos sobre a continuidade do povo judeu devem considerar as mudanças rios estilos identitários em vigor na sociedade atual. Do contrário, cada manifestação de comportamento que se distancia daquilo que as instituições judaicas consideram como a norma "correta" de identificação será, precipitadamente, classificada como indiferença judaica.

A análise das novas modalidades de pertencimento étnico deve ainda levar em conta que este sofre oscilações de intensidade e muda de conteúdo ao longo do ciclo de vida de um indivíduo e/ou família. Assim, um indivíduo que exibe pouca inclinação religiosa aos vinte anos pode se transformar em um judeu religioso ortodoxo aos quarenta ${ }^{6}$.

Enquanto que a autopercepção dos judeus e as maneiras de expressála são heterogêneas, variáveis no tempo e muitas vezes acionadas apenas em contextos específicos, as organizações comunitárias judaicas, mesmo as de natureza secular, continuam a se pautar, em larga medida, pela norma religiosa que estabelece a filiação judaica pela descendência materna ou pela conversão ao judaísmo daqueles que não atendem à primeira condição. É por esta razão que a conversão religiosa desempenha um papel importante

\footnotetext{
${ }^{5}$ Para uma tipologia das várias organizações judaicas ativas na busca de soluções para a "questão judaica" durante o período entre as duas grandes guerras mundiais ver Ezra Mendelson. On Modern Jewish Politics. Oxford: Oxford University Press, 1993.

${ }^{6}$ Aliás, esta tem sido uma trajetória bastante freqüente entre os adeptos da corrente ortodoxa Beit-Habad no Brasil e no exterior.

para aqueles que pretendem vincular-se à vida institucional, organizada da comunidade judaica. Para outros, cuja identidade não se expressa através de unia vinculação organizada ou para aqueles indiferentes a qualquer identidade particularista, os casamentos "mistos" dispensam atos de conversão religiosa. No primeiro caso, a conversão funciona como um "visto de entrada" que facilita a integração à sociabilidade judaica, seja de caráter religioso ou secular.

Nosso trabalho pretende abordar o casamento "misto" por um ângulo pouco estudado, isto é, daqueles que se convertem ao judaísmo. Primeiramente, iremos identificar as características sociológicas dos convertidos quando comparados aos seus parceiros judeus. Procuraremos analisar se a produção de "novos judeus" tem implicado em alteração na composição socioeconômica do grupo judaico. Posteriormente, passaremos a analisar o processo de "judaização" dos cônjuges a partir da percepção daquilo que os torna judeus.

O censo de 1991 identifica a existência de 86.416 pessoas que se declaram de religião judaica. Oriundos, principalmente, da Europa Oriental, mais intensamente nos anos 20, 30 e $40^{7}$, dirigiram-se para os grandes centros urbanos do sudeste e sul do país, especialmente Rio de Janeiro e São Paulo, dedicando-se ao pequeno comércio e à confecção. Parte relevante das gerações seguintes passou a se orientar para as chamadas "profissões superiores", de maior prestígio social. Várias razões explicam esta opção. Roberto Grun ${ }^{8}$ considera que a auto-identificação dos judeus como um povo de "sábios e intelectuais" ajudou os membros das novas gerações a romperem com as atividades empresariais das famílias. Comparando judeus com outro grupo de imigrantes — os armênios — que possui características econômicas semelhantes, o autor não encontra, entre esse últimos, o mesmo processo de descontinuidade ocupacional. A propensão educacional dos judeus pode ser atribuída, também, aos efeitos

${ }^{7}$ Entre 1881 e 1920 chegaram ao Brasil 10 mil judeus, enquanto que entre 1921 e 1940 esse número sobe para 50 mil. Ver J. Lesser. Welcoming the Undesirables: Brazil and the Jewish Question. Berkeley: University of California Press, 1995.

"La estrutura de las comunidades judias y armenia en la ciudad de São Paulo", VIII Conferencia Internacional de Investigación ele la LAJSA, Ciudad de Mexico, 11-14 de noviembre de 1951. 
das práticas religiosas que, pelo menos para o contingente masculino, levou à disseminação de uma alfabetização precoce, a capacidade de adquirir, formular e manipular conhecimentos históricos e combinações de idéias abstratas 9 .

Em ambiente social no qual habilidades daquela natureza eram escassas, conto no caso do Brasil no período áureo da imigração, foram elas, com efeito, facilmente convertidas em recursos econômicos na medida em que o mercado se mostrava favorável e carente de quadros empresariais. A valorização dos estudos contribuiu ainda, de forma mais direta, para a formação dos judeus nas profissões modernas seculares.

Assim, a combinação entre a oferta de oportunidades do mercado de trabalho urbano no país com as predisposições culturais dos judeus resultaram em um intenso processo de mobilidade social seja para atividades empresariais de maior escala seja para profissões superiores ${ }^{10}$.

\section{Heterogamia religiosa e homogeneidade social}

Embora não haja séries históricas que permitam observar a evolução dos casamentos "mistos" de judeus no Brasil, é correto supor que este cresceu na geração dos filhos e netos de imigrantes. Estima-se ${ }^{11}$ que atualmente $20 \%$ dos judeus casam-se com parceiros convertidos e os restantes $80 \%$ se distribuem igualmente entre casamentos coai não judeus e casamentos endogâmicos.

Tomaremos como base de dados os registros ${ }^{12}$ de conversões e

\footnotetext{
${ }^{9}$ Ver a este respeito V. Karady, "Jewish Euterpreneurship and Enterpreneurial Groups from Capitalism to Socialism in Central Europe, with Special Reference to Hungary" A Study of Collective Trajectories and Identities. mimeo s/d.

${ }^{10}$ Para uma visão da distribuição ocupacional da populacão judaica em São Paulo, ver Henrique Rattner. Tradição e Mudança. São Paulo: Editora Ática, 1978.

${ }^{11}$ Estimativa obtida através de entrevistas com lideranças judaicas.

${ }^{12}$ Os registros reúnem formulários preenchidos pelos candidatos à conversão e seus futuros cônjuges durante o período de 1982 a 1990 e textos contendo exposição de motivos dos candidatos à conversão no momento do exame de conclusão da formação. Neste período a
}

casamentos mistos celebrados pela Associação Religiosa Israelita (ARI), sinagoga fundada em 1942 por imigrantes de origem alemã influenciados pelo judaísmo liberal/reformista ${ }^{13}$.

A porcentagem de casamentos "mistos" com conversão sobre o total de casamentos celebrados pela ARI é bastante regular, em torno dos $21 \%$ durante os últimos trinta anos. Entre 82 e 90 , a menor e maior percentagem ${ }^{14}$ foram de $13 \%$ a $32 \%$ respectivamente.

A composição sexual dos convertidos é fortemente marcada. As mulheres perfazem $79 \%$ dos casos de tal forma que podemos afirmar que a ampliação do contingente judaico é concomitante a sua feminização. Levando-se em conta o fato de que a descendência judaica é transmitida matrilinearmente, que o processo de conversão é reais fácil para o sexo feminino, pois não envolve circuncisão, e também a tendência patriarcal da sociedade brasileira, é mais provável que mulheres se submetam ao ritual da conversão acompanhando assim a religião dos maridos.

O grupo de convertidos pode ser considerado, grosso modo, como fazendo parte das classes médias, bem como seus parceiros judeus. De fato, as distâncias sociais entre os cônjuges, se bem que existam, são reduzidas e podem, em geral, ser atribuídas muito mais às características de gênero dos convertidos do que à classe social a qual pertencem.

Alguns indicadores sustentam esta afirmação. O lugar de moradia é um forte marcador simbólico da posição social de um indivíduo no Rio de Janeiro. "Morar perto do mar" constitui um dos principais objetivos que estruturam os investimentos familiares na cidade. A maioria dos judeus como dos futuros cônjuges habita a zona sul da capital (62\% e 56\% respectivamente), que se estende pela orla marítima e onde concentram-se os bairros mais valorizados da cidade. A zona norte é caracterizada por reunir bairros tradicionais como o Méier e a Tijuca habitados, grosso modo,

sinagoga realizou 108 conversões seguidas dos casamentos destes 87 casais que preencheram os formulários.

${ }^{13}$ É a maior sinagoga da cidade do Rio de Janeiro tendo em vista o número de sócios, 900 famílias.

${ }^{14}$ Estimativa obtida através de entrevistas com lideranças judaicas. 
pelas classes médias baixas e que atraiu os primeiros núcleos de imigrantes judeus da cidade bem como de equipamentos e serviços comunitários. $\mathrm{O}$ número de cônjuges judeus desta região é mais do que o dobro (17\%) daquele observado para os de origens não-judaica (7\%). Embora minoritária, a distribuição dos dois grupos na zona periférica, que reúne bairros pobres da cidade, é desigual. Enquanto 14\% dos não-judeus habitam esta zona, apenas $1 \%$ dos judeus declarou ter domicílio nela. O restante é oriundo de outras cidades do país.

Se analisarmos o lugar de origem dos parceiros, caso a caso, segundo uma hierarquia mais fina de bairros, e não apenas de zonas da cidade, que escondem diferenças importantes, teremos que em $43 \%$ dos casos os cônjuges judeus se posicionam em bairros mais valorizados contra $22 \%$ dos de origem não-judaica, enquanto que 34\% habitam bairros do mesmo nível. Ou seja, em $21 \%$ dos casos o parceiro judeu apresenta uma situação mais favorável do que seu futuro cônjuge.

A conversão do cônjuge ao judaísmo e a conseqüente integração desta família à sociabilidade judaica significam que muito provavelmente o casal irá se estabelecer na zona e nos bairros de concentração judaica (zona sul e alguns bairros mais privilegiados da zona norte), significando para uma parcela, ainda que minoritária, de cônjuges convertidos, acesso aos bairros mais valorizados da cidade.

O nível de escolaridade do casal é bastante semelhante. A maioria tem nível superior completo sendo que o limite inferior da escolaridade encontra-se no segundo grau incompleto de apenas $2 \%$ dos cônjuges convertidos. Esta diferença a favor do grupo judaico pode ser atribuída ao fato de que a grande maioria dos convertidos é mulher e que a mobilidade educacional desta é mais seletiva na medida em que se avança na pirâmide educacional $^{15}$.

A distribuição dos cônjuges na escala socioeconômica das ocupações

\footnotetext{
${ }^{15}$ Outra explicação possível seria a diferença de idade entre os parceiros que, no entanto, é comprometida pelo fato de os casamentos se realizarem muito depois da idade média de finalização do terceiro grau.
}

${ }^{16}$ mostra que $52 \%$ dos judeus e $41 \%$ dos convertidos ocupam os quatro primeiros níveis da hierarquia que reúnem as seguintes profissões: médicos, engenheiros, arquitetos, analistas de sistema, economistas, advogados, administradores de empresa, psicólogos, nutricionistas, fonoaudiólogos, comunicadores etc. Entretanto os judeus estão mais presentes nos primeiros níveis: médicos, engenheiros, advogados, administradores de empresas, enquanto os convertidos se concentram entre os psicólogos, nutricionistas, fonoaudiólogos. Esta distribuição desigual corresponde ao perfil de gênero dos convertidos, que sendo majoritariamente feminino orienta-se às profissões tradicionalmente ocupadas por mulheres. Na categoria estudante, por exemplo, encontramos $30 \%$ dos convertidos contra $10 \%$ de judeus.

Talvez aqui, mais do que em qualquer outro indicador, a variável gênero contribui para explicar as diferenças observadas, já que as mulheres, em geral, encontram-se muito pouco representadas nas ocupações de maior rendimento e prestígio social.

Os efeitos da exogamia sobre os casamentos podem ser observados na idade alais tardia em que estes se consumam quando comparada à idade dos casamentos homogâmicos: a média de idade dos casamentos entre judeus é de 28 anos para os homens e 25 para as mulheres, enquanto que para os casamentos entre judeus e convertidos é de 30 anos para os homens e 27 anos para as mulheres. A idade avançada entre esses últimos nos leva a pensar em duas possibilidades: ou os casamentos mistos são uma conseqüência da prévia desvalorização dos indivíduos nos mercados matrimoniais de referência, com reflexos na idade, ou, ao contrário, a natureza mista do casal é que retarda a idade do casamento. Lista última me parece mais provável ${ }^{17}$. O ritual de dissuasão praticado por famílias com alta identificação judaica pode levar muito tempo. Este ritual é, em geral, precedido de um longo período em que o namoro mantém-se clandestino, e envolve muitas fases até a negociação da conversão e seu encaminhamento institucional-religioso. Com o avançar da idade o cônjuge judeu vai se tornando economicamente mais independente enfraquecendo o poder que a

\footnotetext{
${ }^{16}$ Ver Nelson do Valle Silva. Atualização da Escala Socioeconômica para 1980. Rio de Janeiro: LNCC, 1985, mimeo.

${ }^{17}$ Apenas $30 \%$ dos casais responderam a pergunta sobre o tempo de namoro e a média deste grupo é de cinco anos.
} 
autoridade paterna tem nas escolhas matrimoniais dos filhos.

A socialização etnoreligiosa dos cônjuges é bastante forte. Entre os convertidos, 66\% fizeram a primeira comunhão e $45 \%$ frequientaram escolas confessionais. A religião de origem elos convertidos é marcadamente católica $(86 \%)$, sendo $5 \%$ protestantes, $3 \%$ judeus ${ }^{18}$, e $1 \%$ declarou não possuir religião. Esta distribuição é semelhante àquela assinalada como a religião dos pais, sendo que apenas $10 \%$ dos convertidos possuem pais adeptos de religiões diferentes.

Entre os cônjuges judeus a socialização tem algumas particularidades. A prevalência do judaísmo cultural sobre o religioso é marcante. Assim, 91\% freqüentaram escolas judaicas, a maioria de natureza secular/cultural e $51 \%$ freqüentaram movimentos juvenis sionistas. A participação em atividades religiosas é comparativamente mais baixa, apenas $27 \%$ declararam freqüentar alguma sinagoga, e $11 \%$ clubes recreativos. Certamente estes indicadores encontram-se acima da média de frequiência dos judeus cariocas em atividades promovidas pelas instituições comunitárias.

A forte participação deste grupo na sociabilidade judaica, mesmo que não seja pelo veio religioso, explica a importância que a conversão assume para o casal. Esta é uma maneira de reduzir os conflitos identitários, garantindo trena permanência mais cômoda no interior da comunidade e das famílias.

Pudemos constatar que os casais "mistos" pertencem, de uma maneira geral, aos estratos médios da sociedade carioca, e que, portanto, a exogamia não envolve fenômenos de alteração da posição econômica. Gostaríamos de sugerir, entretanto, a título de hipótese, que a conversão implica uma relação de troca por posições simbólicas mais valorizadas. A possibilidade de aquisição de um novo estilo de vida familiar parece acompanhar o entendimento que as convertidas têm do seu casamento com um judeu. Dois aspectos deste ideal de família são, geralmente, destacados. A valorização da prioridade em investimentos educacionais e culturais e a

${ }^{18}$ Tratam-se de casos em que o cônjuge se considera judeu em virtude de ser filho de um pai judeu. Entretanto esta definição contraria a norma religiosa. valorização da coesão familiar. No primeiro caso, a competência em língua estrangeira, cosmopolitismo (mobilidade geográfica, familiaridade com outras culturas, redes familiares em várias partes do mundo), forte consumo de bens culturais, domínio de informações sobre o mundo contemporâneo são vistos como sinais de refinamento atribuídos aos parceiros judeus e à comunidade a que pertencem. No segundo caso, distingue-se a centralidade que os projetos e rituais familiares ocupariam nas orientações de conduta dos seus futuros cônjuges. No período da conversão, estia última imagem se vê reforçada pela ação intensificada dos rituais judaicos familiares que objetivam, em grande medida, a transmissão de códigos "étnicos" ao "novo" judeu e, assim, pretendem assegurar a continuidade do judaísmo nas trituras gerações. A preocupação em preservar a descendência judaica está sempre na ordem do dia deste tipo de casamento. Sua consequiência mais visível na divisão de papéis entre os cônjuges é a ampliação de poder do parceiro judeu na vida doméstica do casal. Muitos domínios da vida cotidiana tradicionalmente geridos pelas mulheres são apropriados ou passam a contar com a participação ativa dos homens. Decisões sobre escola dos filhos, atividades de lazer, círculo de amizades e lugar de moradia, por exemplo, ao serem arbitradas a partir de critérios que atendam ao processo de transmissão, legitimam a autoridade masculina. A importância que a transmissão cultural consciente e refletida assume nestes matrimônios altera o poder entre os gêneros.

\section{O processo de conversão}

Uma das características importantes da instituição religiosa é a natureza dos limites que ela coloca em relação à sociedade mais ampla. A instituição que converte procura socializar, transmitir ao convertido aquilo que, para ela, distingue os judeus.

A Associação Religiosa Israelita filia-se a uma corrente do judaísmo liberal/reformista, surgida na Alemanha, no século passado. Procurando responder à crescente autonomia dos indivíduos face à autoridade religiosa tradicional esta corrente modificou muitas doutrinas e práticas tradicionais do judaísmo como as leis dietéticas, a observância do Shabat, a idéia de uma origem divina da Bíblia, a crença de que os judeus são "o povo 
escolhido" ${ }^{19}$. Conseqüentemente, permitiu aos judeus o desenvolvimento de uma identidade comunitária com baixos custos à liberdade individual. De fato, a participação numa congregação deste tipo pouco afeta as rotinas da vida cotidiana como, por exemplo, as escolhas relativas às atividades profissionais, ao lazer ou lugar de moradia.

O crescimento e consolidação desta sinagoga no Rio de Janeiro é uma expressão da mobilidade ascendente e da prosperidade alcançada por boa parte dos descendentes de imigrantes nas últimas décadas. Tendo como origem um núcleo de imigrantes alemães, pouco a pouco sua clientela se estende para os descendentes de imigrantes vindos de outras localidades, na medida em que a origem geográfica e cultural perde peso na identificação dos judeus brasileiros.

Ao tornar as fronteiras entre os judeus e a sociedade mais amplas e menos marcantes, poucas mudanças de comportamento e estilo de vida são exigidas e esperadas daqueles que se submetem à conversão. A preparação para a conversão implica basicamente na aquisição de conhecimentos judaicos. Cursos de história, tradições, cultura e língua hebraica com duração de nove meses ensinam a identificar certas manifestações coletivas da etnicidade judaica, como as festividades, alguns rituais religiosos, a questão histórica do anti-semitismo, tradições culinárias, a importância do estado de Israel para os judeus etc.

Diferentemente da percepção religiosa tradicional, os reformistas consideram que a religião judaica deve interagir e estar afinada com os desafios que a sociedade moderna coloca aos seus membros. Sendo assim, a religião não aparece como uma alternativa radical aos valores morais do mundo secular, mas como uma maneira superior de vivê-los. Esta complexa "engenharia do contato" é ilustrada nesta passagem, um tanto pessimista, da prédica do rabino para a sua congregação na véspera do ano-novo judaico em setembro de $1995^{20}$. Depois de dizer como é bom e agradável estar reunido cota a congregação na passagem de mais um ano, segue uma indagação:

19 Atualmente esta denominação é a mais importante no Brasil e a segunda maior nos Estados Unidos.

${ }^{20} \mathrm{O}$ título da prédica é A Insatisfação da Pós-modernidade.
Mas, em que estado nos encontramos quando atravessamos os portais de mais um ano da nossa existência? Em que condições celebraremos mais um ano da criação deste mundo cada vez com menos segredos e cada vez mais cheio de novos enigmas? [...] Vivemos sem dúvida unia época de grandes contrastes. Por um lado o mundo atinge estágios de desenvolvimentos sensacionais. Conseguimos evoluir para uma aldeia global hoje mais real do que nunca. Ligamos nosso microcomputador e temos possibilidades ainda mais impressionantes. Mas, ao mesmo tempo, lemos outras notícias que nos enchem de espanto. Os jornais trazem informações permanentes sobre a falta de avanços, ou melhor, a involução da capacidade dos seres humanos de resolverem as suas pendências e seus desentendimentos. Um ano aliás, no início de 5755, vivíamos ainda os efeitos da bomba da Amia em Buenos Aires. Um ano mais tarde constatamos com tristeza que essa forma de resolver as coisas, eliminando o interlocutor do mapa, continua sendo utilizada por diversos grupos pelo mundo afora. Espalha-se uma crescente decepção. Tanto falamos em modernidade, tanto magnificamos essa era da história como quase messiânica, que poderíamos ter esperado dela algo melhor. Estamos a caminho de novos capítulos da história e levamos juntos unta sensação de vivermos numa época quase que pré-histórica... Este sentimento de decepcão tem levado muitos de nós a partir para procuras das mais diversas, possivelmente querendo achar manifestações humanas e espirituais sinceras... E onde é possível encontrar isso? [...] Mais do que o dia do nascimento, que o Rosh Hashaná [ano novo judaico] marque o renascimento do mundo! De um mundo que permita resgatar um pouco da sinceridade e da pureza de sentimentos que alguma vez todos tivemos, e que agora encontramos raramente.

O rabino consente que os membros de sua comunidade estejam integrados à vida moderna fazendo uso dos meios tecnológicos mais modernos. A sua inquietação consiste em saber como compatibilizar a integração neste mundo com valores espirituais. Não está em jogo clamar pela abdicação deste mundo em nome de um estilo de vicia alternativo como é próprio das comunidades religiosas mais ortodoxas. Mas sim a questão de como construir a diferença ao se consentir a integração?

Uma das formas de o rabino desenhar as fronteiras identitárias é a de destacar a importância de certos valores morais que estariam em desaparição ou pelo menos degradados na sociedade. E tão importante quanto isto é mostrar que estes valores já estão contidos nas fontes 
religiosas judaicas. Assim, as prédicas dos rabinos seguem, em geral, uma estrutura básica: para cada valor moral ideal (amizade, solidariedade, humildade etc.) uma ou várias passagens da bíblia são apresentadas a título de ilustração. Ao mostrar que o judaísmo contém em si um ideário que sensibiliza o indivíduo moderno busca-se valorizar o judaísmo frente às ideologias seculares que podem exercer grande atração sobre os congregados. Assim, em outra prédica, o rabino afirma:

Acontece que, um dos graves problemas que nos rodeiam é a deturpação, a deterioração e a destruição de valores. A falta dessas referências fundamentais tem transformado nossa sociedade num verdadeiro reino do aleatório. Confesso que o que mais me afeta, o que mais me agride, é o que tem acontecido com o conceito de amizade.

Lembrando a amizade como ligação de amor, que uniu David ao filho do Rei Sul, Jonatan, e ilustrando com várias passagens bíblicas, a prédica faz votos que durante o ano os congregados possam resgatar este verdadeiro conceito de amizade.

A falta de sensibilidade frente ao problema sociais do mundo que nos rodeia recebe, igualmente, forte condenação do rabino:

Acontece que nos encontramos no estado já antecipado pelo profeta Isaias [E (Deus) disse: vai e diz a este povo: podeis ouvir certamente, aras não haveis de entender. Podeis ver certamente, mas não haveis de Compreender]. Estamos absolutamente insensíveis! Temos perdido a capacidade de nos comover, de nos espantar, de sentir dor. Nossas crianças não sentem mais horror, e nós não conseguimos mais ouvir nenhuma voz. Nem voz de profeta nem sequer nossa própria voz. Uma velha canção espanhola da minha adolescência lamentava a ausência de poetas na província espanhola de Andaluzia: Andaluzia ficou sem poetas. Ficar sem os inspirados que registram a paixão, o amor e outros sentimentos fundamentais é quase tão triste e trágico como ter ficado sem profetas: Andaluzia se ha quedado sin poetas, y... nós sem profetas. Ter ficado sem profetas, porque à falta de ouvidos eles desaparecem, nos priva de um elemento regulador essencial da vida. Ter ficado sem profetas implica que nós nos afastamos de alguns dos caminhos certos da vida, caminhos aos quais devemos retornar.

Assim, o discurso não só enfatiza valores humanistas mas insiste em que estes podem ser encontrados nas fontes religiosas judaicas. Os adversários implícitos da mensagem rabínica reformista não são as comunidades ortodoxas, nem outras religiões, mas as ideologias seculares que exercem forte atração entre os judeus. Colocando-se como opção religiosa no campo moderno a sinagoga busca conquistar a adesão dos judeus que adquiriram uma posição confortável nos estratos médios da sociedade brasileira.

Mas a sinagoga parece não estar satisfeita com a transmissão de uma visão apenas espiritual do judaísmo, isto é, uma visão de que as fontes judaicas podem iluminar valores modernos. Esta postura religiosa passiva deveria ser substituída por outra mais promissora de reconstrução teológica que fortalecesse a opção religiosa de seus congregados. A estratégia enunciada, frente a qual o rabino pressente dificuldades, envolveria uma reforma da teologia no sentido de criar um judaísmo brasileiro.

Qual é a Nossa Identidade Judaica? é o título de uma prédica feita pelo rabino da ARI por ocasião do ano novo judaico de 1995. Após considerar que esta reflexão deve ocupar os membros da congregação durante $o$ ano que se inicia, o rabino expressa seu desagrado com a carência do judaísmo brasileiro de se identificar com os problemas da realidade que o rodeia. Contrastando com a simbiose cultural operada pelo judaísmo alemão e norte-americano ele pergunta:

E por aqui como estamos? Sucedem-se experiências todas elas importadas, sem que se consiga uma identidade judaica local que resista a menor das tempestades. Falta alguma coisa. Falta a dimensão da identificação consciente com alguma coisa que nos rodeia. Seria de se esperar, por exemplo, que nessas últimas décadas tivéssemos produzido uma Hagadá de Pessach de sabor latinoamericano. Por acaso faltariam pontos de contato entre os conteúdos da festividade, e os textos da Hagadá, com o ambiente que nos rodeia? Escravidão, liberdade, famintos e o seu sustento, não teria sido possível produzir um texto próprio que refletisse a tradição milenar e a realidade? [...] Essa possível interseção entre uma visão judaica do mundo e o próprio mundo teria permitido o surgimento de um produto intelectual judaico com raízes no próprio solo local.

As dificuldades em reconstruir a teologia judaica nesses termos que guarda semelhança com os esforços feitos pela Teologia da Libertação no campo católico - devem-se sobretudo à crise atual das próprias 
ideologias seculares, as quais constituem o "outro" do projeto religioso reformista ${ }^{21}$.

\section{Tornando-se judia}

Apesar de o Brasil ser considerado um país com forte componente sincrético e com uma alta taxa de circulação dos indivíduos por diferentes religiões, encontramos entre os convertidos um esforço em legitimar a nova opção religiosa.

Nas "exposições de motivo" apresentadas ao rabino como parte dos requisitos do processo de conversão ${ }^{22}$ encontramos algumas justificativas que dão sentido a este ato. Alguns depoimentos apresentam apenas uma justificativa, outros apresentam várias delas.

Unta primeira forma de dar sentido à conversão é a de conferir um sentido de autenticidade na passagem de uma religião a outra. Trata-se de abordar a conversão como o reencontro de alguma origem familiar perdida. A presença de "cristão-novos" desde os primórdios da colonização do Brasil, difundida através de vários estudos historiográfîcos, facilita acionar esta ancestral idade. Além do mais, o estatuto simbólico desta origem parece conferir prestígio aos seus portadores, haja visto a carga positiva com que esta identificação é freqüentemente enunciada. Dois depoimentos ilustram este percurso:

Me recordo como se fosse hoje, no Yom Kipur eu jejuei e pedi a Deus que inc orientasse na decisão de mudar de religião. No final do dia, vi a primeira estrela e agradeci t Deus pela sua resposta. Meu coração bateu forte, cu já sabia que eu pertencia ao judaísmo, eu me senti uma judia. Durante toda a minha adolescência e juventude sempre gostava de ler, assistir a filmes que falassem sobre o judaísmo, seja nas eras bíblicas como na nossa era. Muitas vezes me perguntava se

\footnotetext{
${ }^{21} \mathrm{E}$ interessante notar que enquanto a religião reformista coloca suas baterias contra as ideologias seculares, o judaísmo ortodoxo vem crescendo no Brasil, como aliás em outras partes do mundo.

${ }^{22}$ Trata-se de trena exposição de motivo que é parte da qualificação do candidato à conversão. Isto poderia supor a apresentação de tuia resposta padrão ao gosto do rabino. Entretanto, a diversidade de elementos contidos nestas autobiografias religiosas se mostraram mais ricas do que o mero cumprimento de unia formalidade.
}

era judia. Eu me identificava com o povo judeu e seus problemas. Às vezes pensava: Querei sabe se meus antepassados não eram (cristãosnovos) judeus convertidos ao cristianismo obrigados pela Inquisição?

As datas passagens revelam a presença de algum elemento mágico, místico, que colabora na tomada da decisão de converter se. Ao fazê-lo a responsabilidade individual pela decisão parece ficar transferida para alguma entidade que está fora de controle. A conversão aparece como imposição de forças externas ou de algum destino histórico.

A segunda justificativa freqüentemente acionada dá à conversão um caráter instrumental. A mudança de religião seria uma ação que busca alcançar finalidades calculadas. Este discurso encontra sua legitimação em alguma versão da ciência moderna, como a psicologia ou a pedagogia. Compartilhar uma mesma religião favoreceria a estabilidade matrimonial e promoveria uma educação mais sadia para os filhos. Estes depoimentos ilustram isto:

Existe interesse [pela conversão] surgiu após conhecer meu noivo. Vamos casar e precisamos ter uma direção para orientar nossos filhos. Meti objetivo religioso é pertencer à religião judaica para que eu possa acompanhar a pessoa que escolhi para casar-me. Quero poder participar de todos os atos judaicos concebidos para a mulher. Converter-se tornou-se então condição básica para poder estar cada vez mais próxima do meu noivo, já que pretendemos nos - casar.

Esta justificativa é aquela que mais convence o rabino. Uma vez que não se pode evitar os casamentos mistos entre pessoas modernas, é importante assegurar que os filhos sejam criados como judeus. Portanto, esta atitude das candidatas de valorizar a família e a tradição do marido é considerada altamente positiva ou, na forma como vários rabinos se expressaram, sincera. Ou seja, ela está se convertendo porque pretende dar origem a uma família judaica e não por qualquer outro interesse considerado menos nobre como, agradar aos pais do noivo, sentir-se mais integrada à família e a amigos do cônjuge ou, ainda, pela presença de algum elemento mágico.

A terceira justificativa se apóia na idéia de continuidade teológica entre os conteúdos da religião original e da nova. Por vezes, a adesão religiosa anterior é minimizada mostrando-se a candidata espiritualmente disponível para abarcar novas crenças. Assim: 
A religião judaica tem valores muito parecidos com os valores católicos, religião em que fui educada, por esta razão não acredito que vá me violentar; Deus é um só.

A percepção de que existe uma continuidade entre as religiões ou que o envolvimento religioso anterior era fraco permite tornar mais confortável o processo de mudança.

A quarta apresenta justificativas de caráter filosemitas e são mais freqüentes entre os homens. Elabora-se uma comparação entre a religião original e a nova concluindo favoravelmente ao judaísmo. Assim, temos os seguintes depoimentos:

Tal atitude [conversão] é decorrente de anos de convivência com membros da sociedade israelita via ambiente profissional e relacionamento social, onde pude captar a essência forte que emana $\mathrm{cm}$ seus integrantes, e que apresentam total afinidade com os meus princípios básicos de vida: cooperativismo, o dinamismo, o altruísmo. Não pensei mais em religião até que conheci [...]. Fui entendendo então que incito diferente do que conheci no catolicismo, o judaísmo é principalmente uma maneira de ser, um modo de vida. A impressão que tenho é que se tornar judeu é ser uma pessoa boa, sempre preocupada em ajudar os outros e tornar o mundo melhor. Numa sociedade individualista e numa época tão narcisista o judaísmo me conquistou.

A adesão à nova religião é o resultado da aplicação de um raciocínio baseado em escolha racional. Compara-se as qualidades de cada unia das religiões e se decide pela mais interessante ou conveniente.

A percepção das convertidas daquilo que as torna judias revela de uma maneira dramática o descentramento da identidade judaica contemporânea. Vejamos um pequeno extrato de depoimento que contém um grande número de significados:

Através de meu marido e com um pouquinho de conhecimento que tenho da religião judaica estou me sentindo bem, obtendo fontes de informação com o meu marido e os seus parentes, os quais me esclarecem o que desejo saber; além disso leio muito sobre religião meu horizonte está bem mais claro. Recebo a Resenha Judaica, Chabad News, O Hebreu, já li vários livros, por exemplo: Golda Meier, Anne Frank, O Holocausto, Exxodos e outros. Já fomos a Israel, visitamos locais históricos, inclusive o Muro das Lamentações. Fiquei emocionada com tudo que vi e senti. Tomei conhecimento do que é o kibutz. Em Israel eu senti que sou uma pessoa privilegiada por Deus.

Este depoimento ilustra bem a inexistência de um centro definidor da identidade judaica. Convivem aí experiências religiosas de tipo ortodoxo (a leitura do jornal Chabad News, órgão oficial de corrente religiosa hassídica), a ligação com a experiência nacional judaica mediante turismo a Israel, o contato com a versão socialista do movimento sionista (o kibutz) e com sua versão religiosa (o Muro das Lamentações), a experiência do Holocausto que é transmitida através de best-sellers americanos, a experiência institucional judaica brasileira (através de seus órgãos de imprensa, como Resenha Judaica e O Hebreu) etc.

A assimilação indistinta destes elementos como expressivos da identificação judaica está longe de ser uma construção específica dos convertidos. Pelo contrário, é uma incorporação muito apropriada do estilo de vida que caracteriza os judeus na atualidade. Mais do que uma experiência que dá sentido às ações e representações do unindo presente como foi até as primeiras décadas (leste século para boa parte dos judeus -, a identidade judaica, hoje, se alimenta do culto ao passado, de guardar a memória. A vivência judaica (literatura, música, cinema, livros sagrados, movimentos sociais e políticos, vida cotidiana, preconceitos e perseguições etc.) é exibida e apreciada como objetos de museu nos quais o tempo se ocupou em desfazer as marcas distintivas. Hoje, todas aparecem como tendo a mesma relevância (ou nenhuma relevância), igualmente válidas para dar sentido à identidade judaica.

Neste contexto de profundas alterações nos estilos identitários, quando o habitus judaico se tornou menos fixo e rígido, o peso dos casamentos mistos pouco comprometem sua performance. Pelo contrário, abre-se a possibilidade de que a oferta de experiências simbólicas judaicas estejam cada vez mais acessíveis a um público que dela deseja participar. 


\section{"Normalizando" o povo judeu: a experiência da Jewish Colonization Association no Brasil}

Bila Sorj ${ }^{1}$

\section{Introdução}

Este trabalho trata de uma experiência judaica de engenharia social nos tempos modernos. Através do estudo de uma experiência histórica, a colonização rural no sul do Brasil comandada pela Jewish Colonization Association, pretendemos argumentar o seguinte:

1) A auto-imagem do judaísmo moderno foi moldada pelo discurso dos filosemitas, isto é, os não-judeus que defendiam a integração dos judeus na sociedade mais ampla. $\mathrm{O}$ filosemitismo, entretanto, não foi um discurso de aceitação dos judeus tal como eles eram. Pelo contrário, argumentava que se os judeus não fossem discriminados e isolados abandonariam seus "vícios" culturais e sociais e passariam a ser iguais ao resto da população;

2) na medida em que os judeus continuavam a manter suas características sociais mesmo em contexto de liberdades civis e políticas, os movimentos sociais judaicos e suas instituições orientaram suas ações para mudar a estrutura ocupacional dos judeus através de vários experimentos de engenharia social e ideologias. O objetivo destas ideologias era "normalizar" o povo judeu;

3) essas experiências de engenharia social estavam baseadas nos pressupostos filosemitas de que a tendência dos judeus de se concentrarem nas áreas urbanas e em atividades de serviço era nina anomalia e devia ser combatida. Conflitos e desentendimentos permanentes emergiram entre engenheiros sociais e as predisposições ocupacionais dos judeus adquiridas ao longo de um processo histórico de longa duração;

\footnotetext{
${ }^{1}$ Professora de Sociologia - IFCS/UFRJ.
}

4) como conclusão podemos sugerir que só no momento atual, chamados por alguns de pós-modernidade, quando as estruturas ocupacionais mudaram dramaticamente em todo o mundo, quando as atividades rurais e manuais estão em declínio, é que os projetos de engenharia social judaicos perderam seu apelo e podem, agora, ser analisados sob um prisma histórico e crítico.

\section{Modernidade e judaísmo}

O judeu medieval construído pela Igreja católica estava condenado, pelo menos até o juízo Final, a permanecer como um ente diferente, sem salvação possível e frente ao qual era necessário manter distância e resguardo.

Não foi necessária a chegada do apocalipse para que se abrisse ao povo judeu a possibilidade de integração à comunidade mais ampla e para que fossem considerados iguais e não mais como fonte de contaminação pecaminosa. Esta possibilidade foi aberta pela modernidade através dos novos valores disseminados pela Ilustração e pela Revolução Francesa.

A integração dos judeus no mundo gentil não foi, como sabemos, um processo unívoco. As versões, a anti-semita e a filosemita, implicavam um projeto disciplinador do povo judeu. A versão anti-semita repunha, em linguagem secular, os preceitos católicos que implicavam na irrecuperabilidade do povo judeu, por seu caráter misantrópico, valores, hábitos e crenças que os tornavam intrinsecamente inviáveis para o convívio social. A versão filosemita concordava com esta caracterização dos judeus, mas se distinguia por considerá-la produto do meio ambiente, particularmente do isolamento a que foram relegados e que face a condições propícias deixariam seus vícios de lado para agir de forma igual ao resto da sociedade.

Embora não se possa precisar a origem do termo "regeneração" no sentido de emancipação, assimilação ou reforma dos judeus, este entrou para uso corrente entre judeus e filosemitas a partir da Revolução Francesa. Consagrou-se no estudo, Essai sur la regeneration phisique, morale et 
politique des Juifs de 1789, do abade Gregoire, que foi um dos principais artífices da emancipação dos judeus na França e foi celebrado pelas comunidades judaicas como seu grande benfeitor. Aquele ensaio é uma tentativa de responder às objeções levantadas contra a extensão do direitos civis e políticos aos judeus. A cada um dos defeitos atribuídos aos judeus, com os quais, aliás, freqüentemente concorda, como por exemplo as leis religiosas, ritos e festas, hábitos e costumes, aspecto físico, o "espírito de corpo", ele alega as circunstâncias provocadas pelo isolamento. No que diz respeito propriamente à fé argumenta que a história tem mostrado o caráter mutante e adaptativo da religião judaica. As reformas a serem empreendidas seriam, sobretudo, na área da educação, treinamento em profissões da indústria, agricultura e militares, supressão dos guetos e a dispersão entre os cristãos $^{2}$.

No capítulo intitulado "Il est possible de former les juifs aux art et métiers et à l'agriculture", o abade responde afirmativamente:

Car observez que nous ne passons pas brusquement aux extrême, nous ne disons pas au Juifs: ajourd'huit fermez votre boutique et demain labourez cette plaine. Il est plus problable que en peu de temps on rendait les Juifs agricoles et bientôt ils s'estimeraient hereux de soigner un marais, de défricher une lande qu'ils fertiliseraient, où ils bâtiraient. Quelques unes de nos colonies, et plusieurs de nos provinces, comme la Bretagne, la Guyenne, demandent des bras; que la voix du goverrnent les appelle dans ces contrées, en les dispersarei parmi les Chrétiens (p. 114 e 115).

Os judeus franceses contrariando as expectativas do abade não se tornara agricultores e tampouco se dispersam entre os cristãos rio período pós-emancipação. Apesar das profundas mudanças na estrutura ocupacional

\footnotetext{
${ }^{2}$ Paul Catrice, em "L'Abbé Henri Grégoire (1750-1831) "Ami de Tous les Hommes" et la Regeneration des Juifs", Mélanges des Sciences Religieuses, Revue Trimestrelle, XXXVI année, $\mathrm{n}^{\circ} 3$, September, 1979, argumenta que o objetivo último do abade era a conversão dos judeus ao cristianismo enquanto que R. Badinter, no prefácio do livro de Abbé Gregoire, Essai sur la régeneration phisique, morale et politique des Juifs, Edition Stock, 1988, o considera influenciado pelos ideais iluministas. Sobre os debates acerca da emancipação dos judeus na França, ver Pierre Birnbaum, "Un régénérateur Jacobin: L'Abbé Grégoire”. In Birnbaum, Pierre, Destins Juifs. De la Révolution française à carpentras: Paris: CalmannLévy, 1995.

e do acelerado processo de mobilidade social, os judeus acabam por se concentrar em certas ocupações específicas: comércio, artesanato e profissões liberais. A ausência de camponeses e o fraco proletariado industrial os diferencia da população cristã ${ }^{3}$. Paralelamente, os judeus franceses não se dissolvem entre os cristãos. Reformulam o judaísmo combinando a herança religiosa com os valores da sociedade circundante (individualismo, patriotismo), ficando a especificidade judaica reduzida ao seu aspecto confessional.

Este padrão de identificação judaica na modernidade européia tem na França sua principal referência e passa a ser difundido de maneira messiânica para todo o judaísmo em outros países através da ação da Alliance Israélite Universelle, entidade sediada em Paris que difunde o judaísmo "à francesa" para outras comunidades do mundo. A solidariedade manifestada pelos judeus franceses para com os seus correligionários em outras partes do mundo pode ser compreendida como a incorporação, por parte deles, dos ideais revolucionários e do seu espírito missionário. Caberia aos judeus franceses a missão civilizatória de lutar pela emancipação política e moral dos seus irmãos de confissão do Leste da Europa $^{5}$,

Não só na França como no resto da Europa, boa parte dos esforços intelectuais e práticos do judaísmo na modernidade foram utilizados para se ajustar à versão filosemita do judaísmo. Em outras palavras, os principais movimentos sociais e do judaísmo em particular, o sionismo e as ações filantrópicas (ORT, colonização rural na América Latina etc.) se orientaram para mostrar que, dadas as condições adequadas, os judeus teriam uma estrutura ocupacional como qualquer outro povo.

${ }^{3}$ Sobre as mutações socioprofissionais dos judeus na França como consequiência da emancipação ver Girard, Paul, Les Juifs de France de 1789 à 1860. De l'emancipation à l'égalité. Paris: Calmann-Lévy, 1976.

4 Para uma história, um tanto apologética, desta instituição, ver Chouraqui, André, L'Alliance Israélite Universelle et la Renaissance Juive Contemporaine (1860-1960), Presses Universitaires de France, 1965, e para uma análise crítica da atuação da instituição durante o "caso Dreyfus", Ver Marrus, Michel, R., Les Juifs de France à l'époque de l'affaire Dreyfus. Paris: Calmann-Lévy, 1972.

${ }^{5}$ A ICA só abraça unia política de emigração após várias tentativas fracassadas junto ao governo russo de melhorar a situação dos judeus naquele país. 
A versão filosemita e suas variações internalizadas pelo judaísmo estavam, obviamente, fadadas ao fracasso. Isto porque supõem que exista uma estrutura "normal" a qual os grupos naturalmente tenderiam a reproduzir, desconhecendo que cada grupo e cultura desenvolvem tendências à especialização em função, obviamente, de contextos históricos particulares que não são facilmente alteráveis por um simples desígnio de vontade e engenharia social. Um povo que durante séculos se concentrou em centros e profissões urbanas, que desenvolveu suas aptidões na área mercantil, artesanal e intelectual não iriam mudar para se ajustar àquilo que dele se esperava. Esta não era, entretanto, a visão dos filantropos judeus desejosos de mudar a imagem degradada que o mundo gentio tinha de seu povo, nem de ideólogos convencidos que a "normalização" ocupacional do povo judeu era desejável e possível.

Apesar do relativo fracasso das expectativas de normalização ocupacional dos filosemitas franceses, o mesmo discurso é retomado por instituições judaicas e servirá de inspiração para a obra de colonização da ICA.

\section{A Jewish Colonization Association}

O grande fluxo de emigrantes judeus da Europa Oriental para outros países durante as últimas décadas do século XIX suscitou um caloroso debate entre organizações e lideranças judaicas sobre a atitude a ser adotada frente à emigração. Divididos entre posições contrárias encontravam-se aqueles favoráveis à emigração como forma de resolver o problema judaico e aqueles que julgavam mais correto envidar esforços para melhorar a situação dos judeus nos países em que estavam domiciliados ${ }^{6}$. Todos concordavam, entretanto, que os judeus estavam sendo forçados a emigrar não somente por razões econômicas mas também devido às perseguições religiosas e políticas a que estavam submetidos e que freqüentemente

\footnotetext{
${ }^{6}$ Para uma discussão dos debates travados entre diferentes organizações e lideranças judaicas européias e americanas vide: Szajkowski, Zosa, "Emigration to America or Reconstruction in Europe". In: American Jewish Historical Society, vol. XLII, no. 2, December, 1952.
}

afetavam suas condições de sobrevivência.

Dentre aqueles que advogavam em prol da emigração destacava-se o barão Maurice de Hirsch, fundador da Jewish Colonization Association ${ }^{7}$. Nascido em Munique, em 1931, pertencia a uma das grandes famílias judaicas dos sécs. XVIII e XIX. Seu avô, Jacob de Hirsch, foi enobrecido pelo grão-duque da Toscana e pelo rei da Baviera tornando-se barão de Géreuth em 1818. Seu pai, Joseph, segundo filho de Jacob, dirigia os negócios da família em Munique, onde nasceu Maurice, do seu casamento com uma mulher egressa de outra grande família judia, os Wertheimer de Frankfurt.

O barão de Hirsch possuía uma das maiores fortunas do mundo e certamente era, entre os judeus, o mais rico. Retirando-se precocemente dos negócios, instala-se em Paris e, sem deixar herdeiros ${ }^{8}$, passa a se dedicar integralmente à filantropia especialmente voltada para os judeus da Rússia. A criação da ICA, em 1891, inaugura um tipo novo de ação filantrópica. Diferentemente das práticas tradicionais da filantropia judaica neste período que objetivavam, principalmente, aliviar as enormes dificuldades enfrentadas pelos refugiados de pogroms e pelos emigrantes que afluíam desordenadamente para as capitais da Europa Central e Ocidental e para os Estados Unidos, a ICA pretendia estabelecer uma expatriação metódica e ordenada de judeus russos. Assim, o barão justifica sua ação filantrópica:

In relieving human suffering I never ask whether the cry of necessity comes from a being who belongs to my own faith or not; but what is more natural than that I should find my highest purpose in bringing to the followers of Judaism, who have been oppressed for a thousand years, who are striving in misery, the possibility of a physical and moral regeneration? - than that I should try to free them, to build then up into capable citizens, and thus furnish humanity with much new and valuable material? Every page in the history of the Jews teaches us that in thinking this I am following no Utopian theory, and I am confident that such a result can be obtained ${ }^{9}$.

\footnotetext{
${ }_{8}^{7}$ A partir de agora utilizaremos a forma abreviada, ICA.

${ }^{8}$ Seu filho, Lucien, morre ainda jovem.

${ }^{9}$ Hirsch, Baron de. "My View on Philantrophy". In Samuel, Joseph. History of the Baron de Hirsch Fund: the Americanization of the Jewish Immigrants. New York: The Jewish
} 
O barão esperava que a emigração seria o início de um processo de regeneração física e moral dos judeus russos, sendo a atividade agrícola o principal instrumento

It has become a maxim and a typical reproach against the Jews that they have no inclination for agriculture or manual labor. That is an error which is contradicted not only by modern examples, but by history. The Israelites in the time of Christ were agriculturalists par excellence, while trade, which, judging from the practice of the Jew today, should be the inherintance of Israel, lay then entirely in the hands of the Phoenicians, the Greeks and the people of the Mediterranean states. The Jews, as long as they were politically independent, cared for their fields, as I have said. They drove their herds, and were handicraftsmen. The tendency towards work in the fields and in the shop existed, therefore, and my own observations and those of others have proved that it is quite possible to reawaken in the race this capacity and love for agriculture, and to bring it into existence again. Of his own power, therefore, the poor Jew, who until now has been hated as an outcast, will win for himself peace and independence, love for the ground he tills and for freedom; and he will become a patriotic citizen of his new home ${ }^{10}$.

\section{A colonização no Sul do Brasil ${ }^{11}$}

O empreendimento colonizador foi concebido para funcionar dentro dos padrões mais modernos de administração de empresas com objetivos que deveriam ser metodicamente executados. Para a constituição do Conselho de Administração Central, com sede em Paris, foram nomeados judeus influentes e bem estabelecidos em atividades financeiras, industriais e profissões liberais, a maior parte deles recrutados entre os membros da Alliance Israélite Universele. O Conselho concentrava todo o poder decisório do projeto.

Publication Society, 1935 (Appendix A), p. 275.

${ }^{10}$ Ibid, p. 276

${ }^{11}$ Todas as informações que se seguem sobre os empreendimentos agrícolas foram retiradas dos Arquivos da ICA/Brasil, Alliance Israélite Universelle, Paris. Para uma história da colonização judaica no sul do país, ver Jeffrey Lesser, Jewish Colonization in Rio Grande do Sul, 1904 - 1925. CEDUAL, VSP, 1991.
O programa de ação da ICA implicou uma complexa organização. Na Rússia são instalados comitês locais de emigração compostos de judeus respeitáveis a fim de selecionar os candidatos, administrar os fundos, controlar, organizar e supervisionar o ajuntamento e embarque dos emigrantes e agir como canal de comunicação entre as autoridades e os emigrantes. Deveria-se obedecer dois critérios na seleção dos candidatos: experiência agrícola anterior e disposição de uma soma em dinheiro suficiente para assegurar a sobrevivência até o aparecimento dos primeiros resultados com a nova atividade.

A obra da ICA não era pura filantropia, mas se organizava como uma caixa de empréstimos. Fornecia, in loco, uma casa, terras, instrumentos de trabalho e alguns animais cujos valores deveriam ser reembolsados. A vantagem deste método era a de estimular os colonos à mais completa liberdade, uma vez que o empréstimo fosse reembolsado.

Nas colônias havia um administrador nomeado por Paris que devia assegurar o bom funcionamento do empreendimento. Estes eram escolhidos entre os antigos alunos das escolas da AIU na África do Norte e Oriente Médio. Saídos de uma condição precária eles sofreriam a influência civilizatória da Aliança e estavam impregnados de valores franco-judaicos ao ponto de demonstrar para com os emigrantes um sentimento que oscilava entre desprezo e paternalismo.

O Brasil entra no mapa da colonização promovida pela ICA como unia extensão de sua ação já empreendida na Argentina. A província do Rio Grande do Sul, no Brasil, parecia altamente adequada para o estabelecimento de colônias. Situada próxima do norte da Argentina, onde estavam localizados outros estabelecimentos da ICA, a região apresentava clima temperado e terras férteis. Por outro lado, o governo brasileiro mostrava-se receptivo ao projeto e concedeu várias isenções e facilidades. Assim, em 1902, foi adquirida no Rio Grande do Sul uma propriedade denominada Philippson ${ }^{12}$, atravessada em sua extensão por uma grande via férrea internacional que ligava o Rio de janeiro à Montevidéu e servida por duas estações.

\footnotetext{
${ }^{12}$ Em homenagem ao vice-presidente da ICA, mais tarde presidente, e morto em 1929.
} 
Quarenta famílias, recrutadas da Bessarábia, com alguma experiência em agricultura $^{13}$, foram encaminhadas, em 1904, para Philippson, distribuídas em 40 fazendas de 25 hectares cada, sendo que parte significativa era de floresta. $\mathrm{O}$ colono recebia um inventário consistindo de terra, casa, animais, instrumentos de trabalho, sementes e subsídio, a título de empréstimo, até a primeira colheita. Homens, mulheres e crianças trabalham primeiramente a cultura de campo enquanto que as zonas de mato, por serem de difícil acesso, necessitavam de uma longa preparação. Mesmo o trabalho no campo tinha que ser feito na maioria das vezes manualmente. Seguem-se dois anos sucessivos de seca anulando os resultados destes esforços. Os colonos se sentem desencorajados e seus filhos abandonam a propriedade para tentar a sorte nas cidades vizinhas. A ICA opera unia completa reorganização de sua programação, distribuindo novos subsídios aos colonos, aumentando o tamanho dos lotes para 50 e 60 hectares cada, organizando o desmatamento das terras de floresta com a ajuda de trabalhadores locais, desenvolvendo a pecuária, instalando uma leiteria e uma cooperativa. A situação melhora gradativamente. Outras famílias judias vêm, espontaneamente, se instalar na colônia e alguns filhos dos colonos retornam.

Das cem famílias instaladas, 52 conseguem quitar dívidas de instalação junto à ICA. Este sucesso motiva a criação, seis anos depois, em 1910; de outra colônia, Quatro Irmãos, com 93.800 hectares sendo 50 mil de floresta que, preparados para a cultura, mostraram-se férteis. Pela experiência adquirida nos outros centros de colonização a ICA prioriza a instalação de colonos com experiência neste tipo de empreendimento. Para tanto recruta os candidatos na Argentina, entre a população judaica já habituada ao trabalho agrícola, e que trabalhavam como assalariados para os colonos.

Em 1912, um primeiro grupo de quarenta famílias se estabelece em Quatro Irmãos. O afluxo de imigrantes foi grande, mas sendo impossível acolher mais do que 90 famílias tenta-se empregá-los em trabalhos de construção de estradas. A maioria não se adapta a este trabalho e deixa a colônia. Em 1914, a ICA se vê forçada pelos colonos a instalar outras 126

${ }^{13}$ Alguns judeus da Bessarábia haviam sido recentemente instalados em zonas rurais através de projetos do governo russo. famílias por eles recrutadas na Europa. Após um curto período de tempo muitos colonos abandonam a nova colônia em função da crise econômica provocada pela guerra européia, o êxodo atinge seu ponto culminante em 1915. A colônia chegou a contar com 200 famílias e mais 89 colonos isolados (ao todo 1.678 pessoas) restando, apenas, 73 famílias (516 pessoas) no fim de 1915.

Este núcleo se mantém estável durante todo o período da guerra, quando a emigração fica paralisada. Esta situação se prolonga no pós-guerra em virtude das restrições impostas à emigração. A obra se estagna em 1926. $\mathrm{Na}$ última tentativa de repovoar Quatro Irmãos instalam-se dois novos agrupamentos constituídos de agricultores escolhidos na Polônia e Lituânia com 24 cultivadores. Em 1926, a população total estabelecida nas duas colônias do Brasil, Philippson e Quatro Irmãos, era de 197 famílias (998 pessoas).

\section{A experiência e o discurso normalizador}

O fracasso do esforço de "normalização" do povo judeu, inclusive em Israel, onde os trabalhadores do campo nunca deixaram de ser uma minoria, levou à produção de uma historiografia onde para cada fracasso se encontram razões conjunturais, específicas, atribuídas às condições locais, pressupondo que, em princípio, o experimento deveria dar certo.

Os modestos resultados apresentados pela obra de colonização da ICA no Brasil, que foram apenas um pouco melhores na Argentina, criaram dificuldades para a historiografia judaica lidar com este evento. Além de ser um fenômeno pouco estudado pela história da imigração judaica na América do Sul, as explicações do fracasso da fixação dos judeus como agricultores parece criar um grande embaraço. A maioria das explicações correntes atribui às condições precárias do solo, em grande parte constituído de florestas, especialmente na segunda colônia, o elemento fundamental no desencorajamento dos imigrantes com as atividades agrícolas. Outros, ainda, sugerem que o autoritarismo e a inépcia administrativa dos funcionários da ICA seriam responsáveis pelo êxodo dos imigrantes para as cidades. Por fim argumenta-se que a instabilidade econômica e política do 
Brasil nas primeiras décadas deste século teriam comprometido o sucesso do empreendimento. Tudo se passa como se os objetivos do projeto, transformar os judeus russos em agricultores brasileiros, não demandassem qualquer reflexão mais pausada e sua frustração devesse ser buscada em um ou outro fator conjuntural.

Entretanto, a análise dos relatórios dos administradores das colônias brasileiras para o Conselho Central da ICA, em Paris, a respeito da primeira década ele colonização revela tensões na própria concepção e desenvolvimento do projeto.

Empresa de colonização ou sociedade filantrópica? Parece seio dilema que assalta permanentemente os administradores bem como os colonos. Se por um lado a ICA procurava se pautar pelos princípios da independência e auto-suficiência dos colonos, por outro sua inserção no mundo da filantropia não poderia deixar de demonstrar certa tolerância frente às necessidades dos colonos. Se os critérios de racionalidade capitalista deveriam prevalecer, pois este era o ethos adequado à promoção de um novo judeu e da assimilação na modernidade, como compatibilizálos com uma ética da solidariedade e um esforço intencional de transformação social?

A administração da colônia, que era totalmente dependente das orientações da sede em Paris, deveria, segundo a concepção do projeto, se envolver o menos possível nos assuntos dos colonos. Estes deveriam ser esclarecidos que não há nada a demandar ou esperar dela, e que o trabalho é a única maneira de atender às suas necessidades. O papel da administração seria tão somente o de facilitar as transações comerciais.

Mas, na prática, a administração era constantemente acionada pelos colonos para solucionar seus problemas de sobrevivência. Os recursos trazidos pelos colonos da Europa, na maior parte dos casos, não eram suficientes para mantê-los até que o empreendimento pudesse dar os lucros esperados. A ICA se vê obrigada a conceder subsídios. A atitude dos administradores frente às demandas por subsídios eram desqualificadoras dos colonos. Em maio de 1905 o administrador da colônia atribui aos maus hábitos dos colonos a demanda de subsídios. Desvalorizados, como "crianças às quais ainda não se pode confiar dinheiro", os colonos são recriminados por praticar um estilo de vida consumista que contrastava com a modéstia dos agricultores locais. A falta de perseverança dos imigrantes, típica da mentalidade camponesa, é ressentida pelos administradores, além de não se acostumarem ao consumo da farinha de milho bem mais barata que a farinha de trigo, costume que trouxeram da Europa ${ }^{14}$. Oferecer subsídios seria antipedagógico:

avec les subsides, ils deviennent imprévoyants et dépensiers ce qu'ils n'auraient certainement pas fait s'ils avaient gagné cet argent à la sueur de leur front, ils seraient, comme on dit, le prix de l'argent.

Mas as sucessivas secas nos dois primeiros anos após a instalação do primeiro núcleo de emigrantes pressionam o administrador local a oferecer subsídios aos colonos. Esta atitude é fortemente condenada pela Administração Central que alerta seu funcionário que a caridade não é compatível com uma obra de regeneração. Coagido pela ameaça de um êxodo massivo de colonos para a cidade, e alguns mesmo advertindo que deixariam suas famílias aos cuidados da ICA, o administrador insiste junto a Paris:

Pouvions-nous réellement abandonner le colon quand cet état de choses était entièrement indépendant de sa volonté? Le colon a fait tout ce qui était en son pouvoir pour faire multiplier à la terre les semences qu'il lui avait confiées (labourer trois fois, herser, biner etc.). Mais pouvait-il réagir contre les effects néfaste de la sécheresse?

A administração central cede e apóia a atitude do administrador local.

Distinguir entre demandas legítimas e ilegítimas, entre aquelas motivadas por adversidades naturais e aquelas provocadas por hábitos condenáveis orientava muitas das decisões políticas da ICA. A primeira deveria contar com a compreensão e tolerância dos funcionários, a segunda deveria ser fortemente combatida.

Mais do que um empreendimento econômico, a obra da ICA (leve ser

\footnotetext{
${ }^{14}$ Os colonos alegavam que a farinha de milho era muito pesada e não convinha para seus estômagos e que jamais se habituariam a comer pão de milho.
} 
entendida como um projeto pedagógico de criação, ou segundo a aspiração do barão de Hirsch, de reativação, de um ethos agrícola entre os emigrantes judeus.

O tipo de política educativa posta em prática pela ICA priorizava a pedagogia do exemplo. Para cada área considerada sensível ao sucesso do empreendimento, procurava-se a superação mediante uma ação que provocasse um eleito demonstrativo positivo nos imigrantes. Assinalaremos algumas destas situações:

a) carência de conhecimentos técnicos.

Do ponto de vista técnico, por exemplo, era necessário orientar os colonos sobre a maneira de cultivar as plantas que eles jamais haviam visto, como a mandioca, cana-de-açúcar, arroz e milho, ou ainda tabaco, caso fossem do norte da Rússia, bem como ensinar o plantio de outras plantas segundo as condições locais de solo e clima. Conselhos verbais dados por técnicos ou inspetores de produção pareciam, aos olhos dos administradores, ineficazes. Era necessário que o agricultor tivesse um exemplo diante dos seus olhos, que visse resultados e decidisse imitar. O meio de consegui-lo foi o de instalar um colono, e sua família, com experiência no país, "um bom trabalhador, aplicado e modesto".

b) a atração da cidade e a ambição do comércio.

Em 1906, aparece na colônia de Philippson um emigrante judeu bemsucedido, domiciliado há trinta anos no Brasil. Motivado pela oportunidade de voltar a conviver entre judeus, planeja se desfazer de seus negócios, solicita ingresso na colônia e apenas um lote de terra. O parecer do administrador é positivo e seu argumento ressalta o valor pedagógico deste recrutamento:

Je pense que la colonization de ce David scra d'un bon exemple pour certain de nos colons qui se plaignent à chaque instant et regrettent d'avoir abandonné le petit négoce qu'ils avaient en Russie. Ils verront qu'ils ont là un coreligionnaire qui n'a pas besoin de travailler la terre pour gagner sa vie, qu'ils a en main un métier plus facile et plus lucratif, malgré cela il abandonne tout et se fait agriculteur comme eux.

Ações exemplares punitivas também poderiam ser acionadas no caso de colonos indisciplinados que insuflam outros colonos. No primeiro grupo de 40 colonos, quatro são classificados como maus elementos. O administrador pede autorização à administração central para expulsar um ou outro destes.

une fois cette mesure prise l'effet ne se fera pas attendre, les outres réfléchiront bien à plusieurs reprises avant de recommencer. La leçon sera salutaire et le restant des colons qui forme en géneral un bon élément nous en saura gré. Bien entendu le moyen radical que je vous propose ne sera pris que dans les cas tout à fait extrêmes où tous les autres moyens ne réussiraient pas avec un colon.

\section{3) emigração para a Argentina}

Em decorrência dos eventos políticos de 1905 na Rússia, muitos colonos recebem cartas de parentes perguntando se poderiam ser colonizados em Philippson. Eram famílias que possuíam recursos e se sentiam ameaçadas pelos movimentos revolucionários em seu país. $\mathrm{O}$ administrador consulta a central, mas antecipa sua opinião:

Je crois qu'on ne ferait pas mal d'accepter comme colons des familles qui possèdent déjá une certain mise de fonds et surtout qui demandent à émigrer au Brésil. L'arrivée de ces familes ici aura pour principal effet de relever le moral de certain de nos colons qui sont imbus de cette idée que 1'Argentine seule est la terre de bénédiction et que le Brésil, parte qu'une année n'a pas répondu à leurs espérances, c'est un pays où il n'y a rien à faire. Ils verront ainsi qu'il y a des familles qui n'ont pas craint de venir engager dans un pays qui hier encore leur était inconnu, tout le pécule qu'elles ont pu amasser, Dieu sait après combien d'années de luttes et de fatigues.

O êxodo dos colonos, sobretudo dos filhos, para as cidades do Rio Grande do Sul, especialmente a capital, Porto Alegre, e para a Argentina, mantém-se durante todo o período da colonização de tal forma que sua continuidade ficou comprometida já em meados da década de 20. Da mesma forma, o afluxo de novos emigrantes para as colônias vai 
gradativamente escasseando.

Se compararmos o sucesso das colônias de alemães e italianos no sul do país com os fracos resultados da colonização judaica talvez poderemos obter algumas pistas a respeito de por que a fixação na terra destes últimos foi uma tarefa vã. A atividade agrícola é uma ocupação que encontra um sentido na vicia comunitária, na tradição, no passado etc. Quando esta existe, como no caso dos imigrantes alemães e italianos, a tradição regional ou nacional do país de origem é recriada no novo solo. Estes últimos viviam no Brasil, mas sua organização social, estilo de vida, hábitos, festas, cultura e língua foram transplantados e reelaborados no país de acolhimento dando aos colonos um sentimento de participação numa "comunidade imaginária", mas forte. Aos judeus faltava uma cultura rural anterior que desse sentido à sua fixação no campo brasileiro.

A inexistência de uma cultura judaica rural que pudesse servir de referência à criação de uma "comunidade" no campo pode ser uma das razões que explicam a rápida assimilação dos judeus na cultura local e a forte atração que a vida urbana exercia junto aos imigrantes russos. Unia autoridade que visita a colônia em 1906 manifesta surpresa com o rápido progresso que os colonos e seus filhos alcançaram no aprendizado do português. Nas colônias alemãs, observa o visitante, era raro encontrar colonos ou crianças que falassem português apesar de já estarem no país há 10 anos. Pode ser também que a forte vontade de integração dos imigrantes russos ao novo país, visando reconstruir completamente suas vidas, fosse incompatível com o isolamento no campo como propunha a ICA. Se a ICA visava a assimilação dos judeus como cidadãos no novo país, o método perseguido de fundar colônias agrícolas parecia seio menos adequado. A cidadania judaica está necessariamente associada à urbanidade. A idéia de "reativar" um ethos rural originado no período bíblico foi uma utopia fracassada, cuja interpretação pode receber a contribuição das pesquisas histórica e sociológica. Através delas será possível avaliar o quanto as propostas filosemitas de integração dos judeus na modernidade estiveram contaminadas pelos estigmas anti-semitas.

\section{Diáspora Minimalista: A Crise do Judaísmo Moderno no Contexto Brasileiro ${ }^{1}$}

\section{Monica Grin ${ }^{2}$}

A crise do judaísmo moderno ${ }^{3}$ no contexto brasileiro vem sendo objeto de tímida análise por parte de cientistas sociais estudiosos da temática judaica no Brasil. Entretanto, alguns estudos isolados, ainda que não apontem direta e especificamente para essa questão, tratam-na implicitamente em seus argumentos ${ }^{4}$. Nas últimas três décadas da recente história da comunidade judaica brasileira, o diagnóstico da crise pode ser identificado não apenas pelas razões comuns à maior parte das comunidades judaicas na diáspora (o Holocausto e o fortalecimento do sionismo coxa a criação do Estado de Israel), mas, e isto tem sabor mais

\footnotetext{
${ }^{1}$ Agradeço à Bila Sorj pelos oportunos comentários. Qualquer erro, todavia, é de atinha inteira responsabilidade.

${ }^{2}$ Professora do Dept ${ }^{\circ}$. de História do IFCS/UFRJ - e co-autora de Judaísmo e Modernidade. Rio de Janeiro: Imago, 1993.

3 Adoto a definição formulada por Bernardo Sorj, segundo a qual o judaísmo moderno caracteriza-se pelas diferentes estratégias de assimilação desenvolvidas através de justificativas coerentes com as idéias iluministas e suas premissas universais; pela adequação do judaísmo aos diversos movimentos político-ideológicos da modernidade, tais como: liberalismo, socialismo e nacionalismo; pela definição plural da identidade judaica; pelo crescente enfraquecimento do judaísmo rabínico; pela tensão entre os pólos tradição/modernidade, etnicidade/cidadania nacional, público/privado e sentimento/razão; e pelo caráter autojustificatório associando judaísmo à ética humanitária e à justiça. Cf., Bernardo Sorj \& Monica Grin (ores.). "Introdução" In: Judaísmo e Modernidade, Rio de Janeiro: Imago, 1991. Excelente abordagem histórica sobre a crise do judaísmo moderno no contexto norte-americano pode ser encontrada em Ezra Mendelsohn, On Modern Jewish Polities. Oxford: Oxford University Press, 1993.

${ }^{4}$ Em Sorj, a definição de judaísmo moderno e sua crise $\mathrm{cm}$ geral é nítida. O autor, ademais, avança algumas proposições sobre o emergente judaísmo pós-moderno (idem); Bila Sorj, em sua pesquisa sobre casamento misto no Rio de Janeiro, identifica a crise do judaísmo moderno em seu desenho comunitário (texto inédito, 1996). J. Lesser não aborda especificamente a crise do judaísmo moderno, embora através dos documentos por ele levantados seja possível deduzir aspectos da crise. J. Lesser, Welcoming the Undesirables, Brazil and the Jewish Question. Berkeley: University of California Press, 1995. Apenas para citar alguns autores.
} 
específico, pelo tipo de interação que foi sendo desenvolvida entre a comunidade judaica e a sociedade brasileira. $\mathrm{O}$ crescente esvaziamento dos valores que orientavam a comunidade de imigrantes, basicamente marcada por subdivisões ideológicas já trazidas das comunidades judaicas do Leste Europeu e da Alemanha ${ }^{5}$ foi motivado também por eventos contingentes da dinâmica político-social brasileira que demandavam a promoção de uma imagem homogênea e de unia institucionalidade representativa da comunidade judaica no Brasil.

No Brasil, as características identificadas com o judaísmo moderno podem ser observadas na gênese espontânea da comunidade de imigrantes judeus que, de alguma maneira, reproduziram aqui não apenas o espectro comunitário do Leste Europeu, fortemente marcado por tensões entre tradição e modernidade, como também, rio caso dos imigrantes judeus de cultura alemã, por valores e comportamentos visivelmente liberais. Essas características, em particular na comunidade judaica do Rio de Janeiro, tiveram eficácia simbólica na manutenção de um universo plural e, ademais, funcionaram como marcadores reais de diferentes interesses e ideais acalentados pelos vários subgrupos que a compunham.

Esse texto tenta identificar e discutir a crise do judaísmo moderno no contexto brasileiro, através da análise político-institucional da Federação Israelita, instituição representativa da comunidade judaica do Rio de Janeiro em âmbitos local e nacional, fundada em 1947. A criação da Federação, pode-se dizer, é uma tentativa, ao menos em sua versão inicial, de conciliação possível das diversas variáveis em jogo nesse período: o impacto do holocausto que redefine o judaísmo e a própria noção de etnicidade judaica, o Estado de Israel e o sionismo como instrumentos políticos eficazes para a sobrevivência dos judeus, inclusive na diáspora, e as pressões do Estado brasileiro no sentido de controlar ondas de imigração e formas de organização de comunidades imigrantes em clara política de acomodação de possíveis conflitos ou diferenciações no âmbito da

${ }^{5}$ É importante salientar que quando me refiro à gênese da comunidade judaica no Rio de Janeiro, estou considerando apenas $o$ estabilishment askenazim. Isto não quer dizer que não viciam no Brasil e, mais especificamente no Rio de Janeiro, judeus sefardim. Entretanto, a tônica institucional da comunidade judaica no Rio era caracteristicamente dada pelas lideranças de origem askenazim. sociedade. $^{6} 0$ ponto a salientar é que a análise da instituição teto da comunidade judaica do RJ, ou seja, a Federação Israelita do RJ, pode revelar importantes contornos da dinâmica étnico-política dos judeus, em particular através de políticas institucionais, mais ou menos coordenadas no sentido de articular pertencimento étnico a demandas nacionais e internacionais $^{7}$. Tal institucionalidade representativa da comunidade judaica, nessa perspectiva, teria, em tese, papel mediador fundamental no sentido de estabelecer e promover possíveis canais de interação entre as demandas do grupo étnico e as expectativas da sociedade reais ampla. Tal como o material empírico revela ${ }^{8}$, esse papel de mediação não se realizou de forma tão nítida. Ao contrário, as crises sucessivas dessa instituição demonstram as dificuldades de mediar e conciliar grupo tão diferenciado em sociedade de cidadania regulada e monolítica ${ }^{9}$.

Proponho, em linhas gerais, a análise da atuação da Federação Israelita do RJ em três diferentes conjunturas: a primeira (1945-60) se caracterizaria por uma definição representativa da Federação, motivada por eventos internacionais e nacionais; a segunda (1960-70) explicitaria tentativas de injunções normativas tanto por parte de grupos conservadores quanto por parte da liderança sionista, tendo como pano de fundo significativas mudanças no contexto político brasileiro por um lado e, por outro, a tensão provocada pelo conflito árabe-israelense de 1967 e 1973; e, por último (1970-80), as estratégias de defesa e atuação pública da Federação em relação ao conflito árabe-israelense, sobretudo quando este é

${ }^{6}$ Cf. Decreto-Lei N. 406 de 4/5/1938. Sobre esses aspectos destaco dois trabalhos. Jeff Lesser, Welcoming the undesirables. Berkeley: University of California Press, 1995, e Giralda Seyferth, "Identidade Étnica, Assimilação e Cidadania: A Imigração Alemã e o Escudo Brasileiro". Revista Brasileira de Ciências Sociais. 26, ano 9. out. 1994.

7 Reconheço que uma melhor compreensão do que seja a crise do judaísmo moderno no contexto da comunidade judaica brasileira exigiria uma pesquisa de viés atais fortemente sociológico, que permitisse explorar diversas facetas dessa crise. A institucionalidade representativa é apenas um locus de manifestação possível do que veta sendo identificado como a crise do judaísmo moderno. A análise de outras instituições (religiosas, educacionais e culturais, por exemplo) da comunidade judaica no Rio de Janeiro garantiria um cenário certamente tais rico e complexo de manisfestação da crise.

O material aqui analisado restringe-se apenas aos arquivos da Federação Israelita do Rio de Janeiro e algumas entrevistas com ex-presidentes da Federação.

${ }^{9}$ Para a definição de cidadania regulada, cf. Wanderley Guilherme dos Santos. Cidadania e Justiça Rio de Janeiro: Campus Editora, 1979. 
introduzido na arena pública brasileira ${ }^{10}$, e o impacto da abertura democrática que promoveria a redefinição do papel da Federação Israelita do RJ.

Minha hipótese é a de que a dinâmica institucional que se instaura na comunidade judaica do RJ, a partir da criação da Federação Israelita, representou, por um lado, razoável tentativa de "proteger" o pluralismo comunitário orientado por um judaísmo de tipo moderno, contra os rompantes normativos tanto do sionismo, fortalecido com a criação do Estado de Israel, quanto da ala conservadora da liderança que tentava impor, desde a década de 20, o modelo de Kehillá $^{11}$ à comunidade judaica do Rio de Janeiro. Por outro lado, a criação da Federação correspondia à necessidade de autodefesa coordenada dos judeus em relação aos poderes públicos, sobretudo diante das pressões esquizofrênicas já na fase final do Estado Novo (ora motivado pela tolerância liberal, ora pelo nacionalismo chauvinista), e depois no período militar.

As sucessivas mudanças por que passa a arena política no contexto brasileiro exigiu permanente negociação das bases de interação dos judeus com a sociedade brasileira, ora fortalecendo o papel representativo da Federação, ora revelando a fragilidade dessa instituição em seu papel articulador e mediador entre a comunidade judaica e o contexto nacional. A maneira pela qual eventos nacionais e internacionais são traduzidos pela liderança formal da comunidade, que se instaura a partir da criação da

${ }^{10}$ Voto do Brasil na ONU, considerando o sionismo uma forma de racismo, o apoio do Itamarati à instalação de uma representação Palestina no Brasil e os massacres de Sabra e Chatila, contribuíram para colocar o conflito palestino-israelense na ordem do dia.

${ }^{11}$ Defina-se kehillá como um tipo de organização comunitária altamente centralizada que possui um corpo executivo que assume a responsabilidade pela manutenção das instituições comunitárias. Nenhuma dimensão da vida comunitária fica fora de sua supervisão. Seu controle é evidente nas atividades econômicas, nas relações com o mundo não judaico. na família, na vida social e em matérias religiosas e educacionais. Esse modelo de comunidade era bastante comum na Idade Média, bem conto no Leste europeu até atais ou menos a Segunda Guerra Mundial. Para cauta análise histórica desse modelo, cf. Jacob Katz. Tradicion and Crisis. New York: Schoken Books. 1971; cf., também, o belo trabalho de Michael Walzer, Spheres of Justice, no qual o modelo de Kehillá é sublinhado como exemplo do que o autor chama formas de entendimentos partilhados. Michael Walzer, Spheres of Justice. New York: Basie Books, 1986. No Brasil, o debate sobre a plausibilidade do modelo de Kehillá inicia-se na década de 20.
Federação Israelita, e as crises sucessivas que essa instituição experimenta quanto à eficácia de sua atuação representativa, revelam uma faceta sugestiva da crise do judaísmo moderno no contexto brasileiro. A homogeneização sociocultural dos judeus promovida pelo processo crescente de assimilação à sociedade brasileira e aos seus valores, as dificuldades de organização da esquerda judaica, em contexto adverso à organização de grupos de esquerda em geral, a sionificação dos interesses políticos da comunidade judaica, a perda crescente da cultura íidiche em cenário societário adverso a diferenciações de natureza étnica, tal como o brasileiro, contribuíram claramente para a crise do judaísmo moderno no Brasil.

Uma tendência mais recente vem desafiando a dinâmica intracomunitária e, conseqüentemente, sua visibilidade na sociedade brasileira. Por um lacto, a abertura democrática no Brasil vem promovendo uma espécie de pluralismo político-cultural, permitindo a organização e a participação positiva de diferentes grupos e movimentos alternativos à representação partidária. Uma espécie de nova etnicidade que reconhece outras identidades como igualmente legítimas (grupos religiosos, negros, mulheres, nordestinos, ecologistas) caracteriza de alguma maneira essa tendência. Por outro, observa-se a retomada das raízes do judaísmo identificado com um judaísmo menos moderno e mais autêntico, menos articulado e racional, com clara valorização do exótico, do diferente e do místico. Das mais recentes definições minimalistas de identidade e pertencimento emerge um cenário desconectado sem síntese possível, sem agenda de consenso. Entretanto, o vazio normativo tem sido de alguma maneira ocupado pela retomada da religiosidade em sua versão consumista e mística. Ainda assim, as dificuldades analíticas diante de etnografias tão complexas e diferenciadas ${ }^{12}$ não permitem sínteses, articulações conceituais ou teóricas para o entendimento do que vem sendo definido como ontologias sociais pós-modernas.

12 Jonathan Webber vem, discutindo de forma extremamente interessante essa diversidade e complexidade etnográfica da etnicidade judaica hoje. Cf. em Jonathan Webber, "Modern Jewish Identities: the Ethnographic Complexitics". Journal of Jewish Studies. 43, (aut. 1992). 
A gênese de constituição comunitária dos judeus na década de 20, em particular no RJ, não foi resultado de predisposição harmônica e consensual dos imigrantes oriundos do Leste europeu. Ao contrário, conflitos de interesses e diferentes conviçcões políticas marcaram o surgimento espontâneo de um universo comunitário dinâmico e plural, onde se recriava mimeticamente o espectro político das comunidades judaicas do Leste europeu. $\mathrm{O}$ arranjo institucional da comunidade judaica no Brasil, tão diferenciado quanto eram as linhas político-ideológicas dos seus membros, não sugere, contudo, cenário caótico. Diria que o dinamismo comunitário, muitas vezes explicitado no conflito entre facções, foi rigorosamente fundamental para assegurar inicialmente a sobrevivência e a manutenção do grupo. A criação de diversas instituições e associações de natureza voluntária garantiam uma subestrutura complexa, quase alternativa à sociedade mais ampla. Com efeito, as bases do conflito situavam-se no interior do grupo e operavam como mecanismos de fortalecimento e revitalização da comunidade judaica. É curioso observar que o conflito ideológico intracomunitário que havia contribuído para o enfraquecimento das comunidades tradicionais do Leste europeu, no Brasil era, ao contrário, expressão de fortalecimento comunitário ${ }^{13}$.

Entretanto, esse dinamismo cultural e político-ideológico situava-se tão-somente nas fronteiras do próprio grupo. No âmbito da sociedade mais ampla verifica-se, ao contrário, entre as décadas de 30 e 40, um período de estridente nacionalismo das elites políticas brasileiras. As estratégias preventivas e autoritárias, no sentido de frear a emergência de forças políticas ou grupos que pudessem colocar em risco a manutenção da unidade territorial ou que pudessem desafiar o poder, tiveram repercussão direta entre os membros do grupo étnico judaico. A legislação federal ${ }^{14}$, fortemente reguladora e restritiva em relação a estrangeiros já residentes ou que pleiteassem entrar no país, teve o efeito de mobilizar internamente o

\footnotetext{
${ }^{13}$ Apenas para que se tenha uma idéia geral da diferenciação de definições ideológicas, entre
os asquenazim, podemos identificar os seguintes tipos: judeu sionista (ele esquerda e de

${ }^{13}$ Apenas para que se tenha uma idéia geral da diferenciação de definições ideológicas, entre
os asquenazim, podemos identificar os seguintes tipos: judeu sionista (ele esquerda e de direita), judeu bundista, judeu socialista, judeu liberal e judeu ortodoxo.

${ }^{14}$ Especificamente em relação ao controle imigratório, cf. Decreto-Lei n.406 de 4/5/ 1938 que cria o Conselho de Imigração e Colonização (CIC ).

grupo étnico judaico para a formulação de estratégias coletivas diante de cenário adverso. Uma agenda de consenso foi, portanto, fundamental para que os interesses coletivos desse grupo pudessem ser publicamente expressados.

A persuasão dos judeus quanto à necessidade de unidade e organização estratégica e decisória ganha, nesta conjuntura, maior força, tendo em vista a instável situação política em cenário nacional e internacional. Ademais, a experiência do anti-semitismo nazista tornará a cooperação dos membros desse grupo inevitável, como meio mais eficaz para se evitar o consumo de uri "anal coletivo" que, em particular, nesse momento, poderia significar o extermínio de todos que, querendo ou não, fossem considerados judeus. Concorre ainda, como incentivo à cooperação, a luta pela criação de um Estado nacional judaico que funcionaria, no cálculo dos que sobreviveram ao Holocausto, como consequiência lógica de maximização da sobrevivência. O movimento sionista, neste particular, terá um papel efetivamente relevante no sentido de mobilizar os membros do grupo em torno a objetivos comuns que incluiriam a promoção de um bem coletivo, ou seja, a criação de um Estado (Israel) como forma de se precaver contra todo e qualquer mal coletivo ao grupo. Com efeito, eventos contingentes não antecipados, nas ordens nacional e internacional foram cruciais para a mobilização de sentimentos étnicos e mecanismos de solidariedade grupal.

\section{Primeira fase: $1945-1960$}

O fim do Estado Novo e o relaxamento político sugerido pela Carta de 1946 irão favorecer a organização dos judeus como atores coletivos com uma base comum de interesses institucionalmente representados. Segue-se que em 1947 é criada a Federação das Sociedades Israelitas do Rio de Janeiro, entidade de base local, que congregava na época 42 entidades, em clara correspondência com o novo momento político que se inicia no Brasil.

Consideremos os objetivos do primeiro Estatuto da Federação 
israelita do Rio de Janeiro ${ }^{15}$ :

a) Integrar no ambiente nacional os israelitas domiciliados no Brasil; b) Representar os interesses da coletividade israelita local perante as autoridades constituídas do país, federações congêneres de jurisdição diferente e quaisquer outras entidades, sempre que a representação coletiva dos israelitas se tornar necessária; c) Coordenar o trabalho das sociedades e comitês federados, respeitando as respectivas autonomias; d) Fomentar a tradição e cultura israelitas difundindo-as particularmente no seio da mocidade; e) Estar vigilante, atuar e agir contra as discriminações de natureza racial e religiosa; f) Colaborar com as coletividades legitimamente organizadas de todo o inundo na defesa dos direitos inalienáveis e imprescritíveis dos israelitas e apoiar o livre desenvolvimento do lar nacional judaico.

As questões arroladas no primeiro estatuto da Federação nos permite reconhecer quais seriam os interesses coletivos de um grupo que possuía uma base claramente diferenciada. As bases de coesão, e é necessário sublinhar, explicitavam-se então através das seguintes variáveis:

a) O fim da Segunda Guerra Mundial e a revelação do Holocausto; b) A mobilização dos judeus de todo mundo na luta pela criação de um estado judaico; c) A afirmação do princípio da sobrevivência étnica como o mais importante elemento de sustentação da identidade judaica e do judaísmo; d) A homogeneização dos membros do grupo não apenas em relação à reafirmação dos sentimentos étnicos, mas também em relação às condições sócioeconômicas tornando seus valores e interesses mais coesos.

Podemos deduzir, com base nos objetivos do Estatuto, ao menos duas concepções políticas de etnicidade: uma, de expressão universalistahumanitária e, portanto, interacionista, e outra particularista e preservacionista. No primeiro caso, reflexo de tendências liberais do pósguerra, podemos observar uma concepção universalista mais ampla (cláusula $e$ ), segundo a qual os judeus devem envolver-se nas lutas universais pela justiça e pelos direitos humanos, porque tal atitude significaria uma espécie de garantia de que os judeus teriam seus direitos respeitados como indivíduos e como grupo. Esse argumento postula que

${ }^{15}$ E importante salientar, que os estatutos da Federação seguem orientação do Jewish World Congress, instituição chie congrega as comunidades judaicas da diáspora. somente quando as injustiças e desigualdades estiverem completamente abolidas, os judeus poderão se sentir seguros. Ainda segundo essa perspectiva, lutar a batalha dos oprimidos e perseguidos significaria indiretamente o alcance de benefícios aos judeus, vítimas históricas de perseguições e discriminações. A esse mecanismo de luta corresponderia uma boa dose de humanitarismo universalista e democrático como estratégia e alvo para a ação coletiva.

No segundo caso, podemos observar o fortalecimento da tendência sionista (cláusula $f$ ) quando afirma a luta pela criação de um lar judaico como possibilidade de sobrevivência do povo judeu e do judaísmo. Tal tendência fortalecida diante da comprovada fragilidade dos judeus no mundo, postula que a sobrevivência e a segurança dos judeus depende única e exclusivamente da sua luta pela criação de um Estado nacional que jamais permitiria a reedição de qualquer forma de anti-semitismo ${ }^{16}$.

Pacto entre as entidades que compunham a Comunidade judaica em nome de uma supra-instituição que as representassem publicamente justificava-se em um período em que eventos de natureza adversa a este grupo étnico tiveram o efeito de revelar sua fragilidade, sobretudo quando se tratava da defesa de seus interesses em processo de interação com a sociedade maior. Nestas condições, a criação de um arranjo institucional tornava-se crucial para que se pudesse resolver problemas de coordenação e mobilização dos membros das entidades em universo relacional marcado pelo conflito. Ademais, acreditava-se que a delimitação e racionalização de objetivos e estratégias de ação implicaria a redução de incertezas que, como já vimos, significava para esse grupo um modo possível de se precaver contra "possíveis tragédias futuras". A atuação representativa da Federação, no final da década de 40, resumia-se às seguintes deliberações: protesto junto a Associação Brasileira de Concertos contra o pianista alemão Walter Gieseking, convidado por aquela associação para uma série de concertos na capital federal. Tal protesto atendia a denúncias de envolvimento do pianista como regime nazista - membro militante da Liga para a Cultura Germânica; elaboração de um memorandum para o governo brasileiro rio sentido de influenciar $o$ voto brasileiro na ONU contra a internacionalização de Jerusalém; e mediação de conflitos entre subgrupos

${ }^{16}$ P. Medding, "Patterns of Political Organization and Leadership in Contemporary Jewish Communities". In: Daniel Elazar, Kinship and Consent, the Jewish Political Traditions and its Contemporary Uses. Ramat Gan: Turtledove Publishing, 1981, p. 276. 
da comunidade judaica.

A manutenção da Federação Israelita do Rio de Janeiro, até sua primeira crise em 1957, parecia possível, em grande parte, pela congruência daquelas variáveis que sustentavam a seguinte premissa: se representação institucional centralizada, então segurança e estabilidade para o grupo étnico judaico no Brasil. Entretanto, e em 1957 isso fica cada vez mais claro, as bases do consenso que garantiam a manutenção da Federação e que repousam prioritariamente em sua natureza representativa, ficam ameaçadas por tentativas de injunções normativas de subgrupos que compunham a comunidade. A análise de sucessivas atas de reuniões nos dez primeiros anos da Federação revela que, na ausência de eventos que trouxessem à superfície questões que significassem adversidades reais ou potenciais, muito dificilmente estaria assegurado o consenso que possibilitara a criação da Federação Israelita do Rio de Janeiro.

A década de 50 no Brasil caracteriza-se, na lógica de integração dos judeus à sociedade brasileira, como a "idade de ouro" da segurança dos membros desse grupo. Economicamente o país atravessava uma fase de grande expansão industrial e dinamização urbana atendendo aos anseios de uma classe média de identidade cada vez mais fortalecida. As oportunidades de ascensão social, via mercado, tornavam-se cada vez mais nítidas, sobretudo para profissionais habilitados e de formação superior. Politicamente, o país respirava ares de democracia não apenas através de sua dinâmica político-institucional, como também através da diferenciação e de disputas entre grupos de interesses, revelando timidamente a formação de um cenário pluralista.

A ecologia social naquele momento estimulava as possibilidades de assimilação dos membros desse grupo pois, em matéria étnica, a sociedade brasileira não exibia mecanismos explícitos de diferenciação. A desmobilização política de grupos diferenciados favorecia a mobilidade e ascensão social dos judeus cuja identidade não comprometia seu ingresso em cenário social. Segundo Hasenbalg, “[...] a imagem da harmonia étnica e racial como parte de unia concepção ideológica mais ampla da 'natureza humana' brasileira é associada a um mecanismo de legitimarão destinado a dissolver tensões, bem como a antecipar e controlar certas áreas de conflito social" (1979, p. 245). E, finalmente, quanto ao mercado de trabalho, as possibilidades de integração dos judeus pareciam não exigir nenhum esforço específico desse grupo para a defesa dos direitos relacionados à igualdade de oportunidade e à cidadania.

Com o escopo de atuação representativa diminuído pela ausência de adversidades externas explícitas, iriam se tornar claras as bases contingentes do contrato sobre o qual se constituía a Federação israelita do Rio de janeiro. Os interesses das entidades que compunham a Federação, até então orientados para necessidades representativas (tendo em vista aquela conjuntura adversa), deslocam-se, em período de pouca pressão externa, para os dilemas sobre a definição normativa mais apropriada àquela instituição.

\section{Segunda fase: $1960-1970$}

No final da década de 50 relevantes lideranças de entidades da comunidade judaica do RJ retomariam uma discussão que teve início na década de 20 e que nunca deixou de ser pensada como saída para toda e qualquer crise institucional. $\mathrm{O}$ que estava em jogo nesse debate era a plausibilidade ou não de uma mudança institucional que levasse em consideração a possibilidade da Federação exercer papel normativo além do representativo que ela já possuía.

Duas tendências normativas monopolizavam o debate naquela ocasião. 0 sionismo, na conjuntura do pós-guerra, afirmara-se como tendência ideológica de maior persuasão entre os judeus de todo inundo para a manutenção da identidade judaica. A sionificação do judaísmo ${ }^{17}$ revelava-se como alternativa vitoriosa de reestruturação laica de um judaísmo dilacerado pela dúvida religiosa e pela perplexidade dos judeus diante do Holocausto. Na lógica do sionismo, portanto, o Estado de Israel se afirmaria como o centro por excelência irradiador de definições, decisões e formulações normativas para as comunidades judaicas da diáspora. No Brasil, como em toda a América Latina, o movimento sionista, antes apenas uma linha ideológica, verá seu escopo de influência alargado mobilizando, através de seus valores, os judeus em torno do princípio da sobrevivência. O sionismo no Brasil, ao institucionalizar-se, passa a ter influência direta nas tomadas de decisão da Federação Israelita ${ }^{18}$.

${ }_{17}$ Bernardo Sorj, "A Dialética do Holocausto". Novos Estudos Cebrap, 2 (jul 1983).
${ }^{18}$ Em carta ao Jewish, World Congress, datada de 19 de maio de 1949, o presidente da
Federarão, prof. Feigl, assim se expressa em relação à Organização Sionista Unificada: 
A outra tendência de mudança institucional baseava-se na retomada da definição étnico-religiosa do judaísmo. Segundo os adeptos dessa tendência, o modelo institucional mais adequado seria a Kehillá, que representaria e organizaria comunitariamente os "indivíduos" judeus e não entidades federadas. Argumentava-se, neste caso, que vários membros da comunidade judaica não seriam afiliados a nenhuma das entidades federadas que compunham a Federação e, por esta razão, não poderiam ver suas demandas representadas. Entre os objetivos do modelo de Kehillá encontram-se, por exemplo, o fortalecimento da definição religiosa de identidade judaica, a individualização dos membros da comunidade judaica, a retomada de princípios tradicionalistas como base normativa para o comportamento dos membros, o esvaziamento das diferenças ideológicas no interior da comunidade e a discrição na elaboração de canais interativos com a sociedade mais ampla e o fortalecimento da dinâmica comunitária como antídoto à assimilação crescente dos membros aos valores desta sociedade. Às injunções conservadoras dos que defendiam o modelo de Kehillá seguiu-se fortíssima reação de considerável número de entidades federadas, sobretudo aquelas de orientação liberal ou de esquerda. Todas defendiam, em seus argumentos, a autonomia das federadas contra as tentativas de intervenção e eram favoráveis à manutenção de uma organização comunitária democrática, ou seja, sem o monopólio normativo de uma definição de tipo mais religiosa e tradicionalista. A tendência conservadora de parte da liderança seria, portanto, rejeitada em nome do espírito democrático e interacionista de uma comunidade étnica ainda plural em um contexto nacional igualmente motivado para a consolidação democrática.

As conjunturas nacional e internacional nesse período garantiram, mais uma vez, a sobrevida da Federação como instituição representativa, sobretudo porque alguns importantes desafios emergem nesse contexto exigindo um posicionamento mais objetivo. No cenário internacional, a radicalização do conflito árabe-israelense, em 1967 e em 1973, colocará a Federação diante da tarefa de estimular e reacender sentimentos de solidariedade e civismo em relação ao Estado de Israel. A retomada ad hoc

"[...we have to step over a lot of difficulties, specially regarding our relations with Organização Sionista Unificada which is trying to maintain beside the supremacy in zionist matters - we agree with this - also in all kinds of matters of local character and to interfere in our competency". do discurso da coesão e da inevitabilidade de um destino comum reafirma, mais uma vez, o diagnóstico de que a base do consenso entre entidades representadas pela Federação era contingente, ou seja, para que ocorresse era necessário que acontecimentos que independem da vontade dos agentes os fragilizassem diante de adversidades e ameaças potenciais.

O impacto das guerras árabe-israelenses de 1967 e 1973 demonstraria a centralidade de Israel na vida dos judeus brasileiros. Israel, e estas guerras demonstravam, passa a ser o elemento de união das diferentes tendências ideológicas no interior da comunidade judaica e, ademais, da Federação. Com efeito, o princípio da sobrevivência, cuja idealização está na própria existência do Estado de Israel, mais uma vez, reafirma-se como fator de sustentação e manutenção da identidade étnica desse grupo.

Será nesta conjuntura, em particular, que a sionificação da comunidade judaica do Rio de janeiro tornar-se-á mais explícita. Desde as instituições propriamente sionistas, passando por parte dos grupos de esquerda, escolas e movimentos juvenis, todos, de alguma maneira, se mobilizaram pela causa israelense no conflito do Oriente Médio. Pode-se assumir, inclusive, que a emergência de uma espécie de sentimento étniconacionalista, por conta do conflito árabe-israelense, fora também favorecido pelo cenário político brasileiro de então.

O Brasil do final da década de 60 retomava sua versão autoritária com a implantação do regime militar em 1964. A interrupção do processo democrático e, em conseqüência, do funcionamento das instituições democráticas, reativa a histórica insegurança dos judeus pelo desconforto da instabilidade política. Diante de uri cenário político-social de incertezas, novas estratégias serão formuladas tendo em vista uma adaptação nãoproblemática a esse novo momento ${ }^{19}$.

A repressão política, radicalizada a partir do final dos anos 60, promoverá o retorno dos membros à dinâmica comunitária. Tal retorno significava a revitalização étnica em versão sionista. $O$ fechamento de canais participativos na sociedade brasileira tornaria a participação comunitária atraente, sobretudo para as gerações mais jovens. Era comum, nessa conjuntura, referir-se a Israel como cenário da utopia socialista, desanimados e impedidos de imagina-lá ou realizá-la no Brasil. É bastante

${ }^{19} \mathrm{O}$ silêncio das fontes da Federação cota relação a esse período dificulta o conhecimento e analise detalhados dos juízos e avaliações da liderança comunitária. Alguns depoimentos e informações autorizam, todavia, algumas tímidas observações. 
sugestivo que vários judeus brasileiros de esquerda, fugindo da clandestinidade imposta pelo regime militar, tenham abraçado a causa israelense na guerra de 67, exilando-se em Israel. Verifica-se, neste novo cenário, que mesmo uma parte cios grupos de esquerda da comunidade judaica, que antes se opunham ao sionismo, passam a incorporá-lo, articulando-o às idéias socialistas, numa clara demonstração que Israel, naquele momento, correspondia aos anseios de uma esquerda judaica sem lugar no Brasil. Mais uma vez, então, o sionismo se mostrará um potente elemento de coesão e mobilização dos judeus no cenário brasileiro.

\section{Terceira fase: $\mathbf{1 9 7 0 - 1 9 8 0}$}

No início da década de 70, a Federação Israelita do Rio de Janeiro adota clara estratégia de democratização institucional na tentativa de mobilizar o voto direto de membros isolados e entidades, quase como um contraponto ao ambiente autoritário da sociedade mais ampla. A intenção era a de atrair membros potenciais já afastados da vida comunitária e refratários à dinâmica institucional da Federação.

$\mathrm{Na}$ sociedade brasileira verifica-se igualmente algumas transformações. Um inegável dinamismo sócio-econômico que garantia progressos materiais substantivos para a classe média favorecia a tendência à assimilação. Integrados à lógica do mercado e vivendo expectativas de ganhos, comuns à época do "milagre econômico", os judeus irão buscar novas formas de associação profissional e social no âmbito da sociedade maior. O impulso associativista que se inicia na segunda metade da década em questão fará surgir novas identidades coletivas organizadas e constituídas, sobretudo por profissionais de classe média, alternativas à estrutura corporativa oficial ${ }^{20}$.

Algumas questões, todavia, desafiavam as estratégias de atuação da Federação: como deter a tendência assimilacionista? Como renovar e atrair novos quadros dirigentes? Como atrair novas gerações para o estudo e o interesse pela cultura judaica? Como estreitar laços com Israel a fim de que os judeus da diáspora não percam totalmente sua identidade étnica? ${ }^{21}$

Em 1975 é elaborado um novo Estatuto para a Federação no qual

\footnotetext{
${ }^{20}$ Renato Boschi, A Arte da Associação. São Paulo: Vértice, 1987.

${ }^{21}$ Relatório do Conselho Executivo - gestão Eliezer Burlá- em 25 de setembro de 1973.
}

duas novidades são reveladas. A primeira é a realização de uma antiga idéia: transformar indivíduos isolados em eleitores. Para que se tenha uma idéia, a eleição de 1976 para o Conselho Deliberativo da Federação teve nada menos do que 127 candidatos; a outra, é a inclusão de uma nova cláusula nos objetivos da Federação: "Promover campanhas de esclarecimentos sobre as atividades da comunidade israelita, assim como de sua participação na vida comunitária do País".

Ora, a inclusão de um item dessa natureza nos permite especular sobre duas possíveis estratégias da Federação neste período: 1) a iniciativa de uma integração maior à sociedade brasileira como forma de atrair os membros assimilados ou em vias de assimilar-se, e/ou; 2) considerando a política de aproximação do governo brasileiro com os países árabes devido a crise do petróleo $(90 \%$ do petróleo importado provinha de países árabes, em particular do Iraque), o apoio do governo à resolução da ONU que definia o sionismo como uma forma de racismo, e a simpatia manifestada, por parte do Ministério das Relações Exteriores, pela criação de unia representação da Organização para a Libertação da Palestina (OLP) no Brasil, tornava-se urgente uma reavaliação do papel das Federações israelitas no cenário público brasileiro.

O mais curioso neste caso é que o governo brasileiro transfere para a arena pública brasileira um conflito internacional que até então não despertava maiores interesses nem para o governo, nem para a intelligentsia e nem para a esquerda já bastante esfacelada naquela ocasião. Ainda assim, causa perplexidade que neste conflito tanto a esquerda quanto o governo brasileiro, tendo o Itamarati como porta-voz, apoiavam a mesma causa ${ }^{22}$.

Dado esses desafios, a década de 80 será palco de curiosa mudança no que se refere à atuação da Federação em cenário público brasileiro. Unia espécie de agressividade interativa através do uso permanente de meios de comunicação de massa, para fins de esclarecimentos, denúncias, demonstrações cívicas, por um lado, e de canais formais - judiciário, legislativo e executivo - por outro, traduziriam essa mudança nas estratégias da Federação. Os documentos da Federação, nesse período, resumem-se a correspondências para presidentes, governadores, prefeitos e

${ }^{22}$ É interessante notar como o Itamarati em pleno regime militar tenta assegurar, ao menos para tora, uma imagem humanitária e solidária, quase sempre $\mathrm{cm}$ favor de povos oprimidos, quando no cenário político brasileiro a repressão a grupos de esquerda persistia nos porões da ditadura. 
deputados (buscando apoio para questões relacionadas aos judeus no Brasil e no mundo), a notificações contra manifestações pró-OLP ${ }^{23}$, a denúncias em jornais de grande circulação, a lobbies junto ao legislativo, sobretudo junto a deputados judeus ou simpáticos à causa judaica, enfim, documentos que atestam uma clara mudança na orientação política da Federação. Nesse mesmo período a Federação se transforma em instituição de utilidade pública em decreto assinado pelo então presidente João Batista Figueiredo, em clara tentativa de afirmar-se como entidade coletiva visível e participativa na dinâmica societária brasileira.

Essa nova postura da Federação apresenta uma diferença crucial em relação ao "silêncio" e discrição quanto às questões nacionais, no período anterior. Um senso de pertencimento, de mobilização cívica, parece traduzir o perfil político que a Federação adota nesse momento. Duas questões, portanto, devem ser sublinhadas para o entendimento dessa mudança: a primeira refere-se à insegurança circunstancial provocada pela surpreendente e efetiva atuação dos grupos pró-causa palestina em cenário público. A não-intencionada exposição a que foi submetida a comunidade judaica acabaria estimulando a sua politização, maneira pela qual ela poderia enfrentar a oposição daqueles grupos. ${ }^{24}$ Tratava-se de afirmar a "brasilidade" dos judeus contra o sionismo do qual eram acusados, bens como persuadir a opinião pública e o governo de que a OLP era uma organização terrorista, contrária à estabilidade e à ordem social. ${ }^{25}$ Pela primeira vez, a Federação se verá "forçada" valer-se da cidadania brasileira para defender sua causa étnica numa competição típica de cenários pluralistas.

Via de regra, essa nova postura da Federação promoveria conflitos de avaliação entre os membros da comunidade judaica, permanecendo ainda

${ }^{23}$ Os massacres de Sabre e Chatilla exigiram maior esforço da Federação no sentido de dissociar a comunidade judaica do Brasil dos abusos militares cometidos por Israel. As críticas a Israel foram mais fortemente manifestadas pela esquenta brasileira.

${ }^{24}$ Pela primeira vez a liderança representativa da comunidade se vê diante de um problema cuja resolução não se realizaria, de forma eficaz, pela estratégia do "judeu de corte", ou seja, resolvendo problemas através de negociações silenciosas junto aos poderes públicos. Ao contrário, o uso da imprensa, como instrumento democrático de defesa e denúncia teve de ser largamente adotado ao longo de toda década de 80 .

${ }^{25}$ A disputa ele versões sobre o conflito palestino-israelense entre os líderes da comunidade judaica e líderes palestinos esteve presente em jornais, de todas as tendências, ao longo das décadas de 70 e 80. hoje matéria controversa entre os judeus, dentro e fia da Federação. Dois tipos de juízos sobre a estratégia de politização da Federação podem ser observados na comunidade judaica do Rio de Janeiro:

1) Desfavorável. Tal juízo postula que expor a comunidade judaica em "mercado" político pode representar um risco em país de democracia recente e ainda instável. Expor-se na arena pública poderia significar um risco para os interesses relacionados à sobrevivência e segurança dos judeus no Brasil. Segundo um dos mais influentes membros da comunidade judaica do Rio de Janeiro, ex-presidente da Federação,

[...] a comunidade judaica não é uma comunidade politizada. Ela pode até ser politizada, mas não é política. Ela não é uma unidade política. O erro todo está nisso. Há pessoas que querem se eleger a cargos eletivos cone essa tecla, tentando afirmar algo que é uma mentira deslavada: que a comunidade judaica deve votar no candidato judeu como se ela fosse unia unidade política. Eu não posso desconsiderar o fato de que certos candidatos judeus não merecem nem um voto. Acho até que há candidatos que não deveriam ser candidatos. ${ }^{26}$

2) Favorável. Esse juízo vem se manifestando com maior vigor, pari passo com o processo de democratização da sociedade brasileira. Entretanto, podemos deduzir duas posições bastante heterogêneas a primeira, referente aos chamados judeus progressistas socialistas e comunistas - que buscam uma maior participação do grupo étnico-judaico na dinâmica social brasileira, assumindo para si problemas que extrapolam as fronteiras étnicas, posicionando-se como grupo progressista na luta pela democracia e pela justiça social.

Se o anti-semitismo e a discriminação de qualquer espécie são fenômenos social e historicamente provocados, podem ser eles socialmente corrigidos. Comprar esta briga significa juntar forças com os elementos verdadeiramente transformadores da sociedade brasileira, aqueles que lutam pela solidariedade, contra $o$ individualismo e o egoísmo. Significa, também, perceber que não há solução para a "questão judaica" fora de unia batalha mais ampla que incorpore outros segmentos sociais no caminho que leva a uma

\footnotetext{
${ }^{26}$ Entrevista, em 26/9/90, com o Dr. Samuel Malamud, ex-presidente da Federação e ex-
} cônsul honorário de Israel no Brasil. 
sociedade justa e democrática. O judeu, afinal, é um cidadão mergulhado na cidadania e não está acima dela ${ }^{27}$.

A segunda posição, que não goza da influência dessa ou daquela tendência ideológica e, nesse sentido, formula estratégias múltiplas de ação, sem muita coerência ou consistência com valores especificamente judaicos ou universais. Sem critério de participação coerente na sociedade maior, o princípio que prevalece é o da exposição por ela mesma, ou seja, "[...] a gente resolve as coisas indo para a rua, botando a cara, dizendo quem a gente é, indo para os poderes instituídos, principalmente o legislativo, para conseguir as nossas coisas",28.

No conflito intracomunitário, com efeito, atribui-se aos adeptos da estratégia da visibilidade do grupo étnico, o uso da Federação como trampolim para a obtenção de cargos eletivos - municipais, estaduais e federais — tendo por base eleitoral a própria comunidade judaica. Em comunidade heterogênea, tal objetivo repercute de forma controversa. Os que acreditam na plausibilidade do voto étnico no Brasil apóiam candidatos judeus comprometidos com plataformas especificamente voltadas para as demandas da comunidade judaica. Já os que não acreditam na eficácia do voto étnico postulam que candidatar-se a cargos eletivos como judeu significa responsabilizar toda a comunidade judaica quando sua atuação pública repercutir negativamente na sociedade maior.

Muitas vezes eu posso confiar mais em um deputado que não tenha origem judaica do que em um deputado judeu pois, se ele cometer alguma bobagem ou não for um político capaz, poderei ser responsabilizado se o responsabilizarem como judeu. As conseqüências dos seus atos podem repercutir sobre a minoria étnica que não tem nenhuma responsabilidade ${ }^{29}$.

Nos dias atuais, o Brasil vem conhecendo uma sociedade inegavelmente plural, com grupos de interesses organizados, em visível

27 "Editorial", ASA: Judaísmo e Progressismo, Órgão Informativo e de Divulgação Cultura da Associação Scholem Aleichem de Cultura e Recreação, 2, ano I, out. 1989.

28 Entrevista com o Dr. Milton Nahon, em 19/12/90, ex-presidente da Federação e, atualmente, vereador do município do Rio de Janeiro.

${ }^{29}$ Entrevista com Dr. Samuel Malamud, cf. nota 26. processo de consolidação democrática. Entretanto, ao lado desse cenário otimista, convive-se com um outro cenário no qual indiferença e descrença quanto a ideologias e instituições políticas vêm pouco a pouco destituindo a arena pública de qualquer eficácia real ou simbólica. A segurança e a confiabilidade só existem no estrito âmbito do privado, da reclusão familiar. A imprevisibilidade do mundo social e a incerteza da vida moderna, fragmentada e sem sentido aparente, decretam a falência da racional idade presente no judaísmo moderno e derrotam qualquer tentativa de síntese da vida comunitária.

Uma ontologia social pós-moderna, ainda que não facilmente apreensível no Brasil, exigirá do analista um diferente olhar em relação às formas particulares e minimalistas da relação dos judeus com a sua tradição. A promoção e a positivação de aspectos da tradição (raízes, hábitos, religiosidade, etc.) como elementos de diferenciação dos indivíduos em sociedade homogênea, marcam uma relevante diferença em relação ao judaísmo moderno que, ao contrário, tentou conciliar tradição e modernidade pela universalização dos valores judaicos. 


\section{Intelectuais na comunidade judaica brasileira}

Roberto Grün ${ }^{1}$

Esse texto pretende dar conta de algumas particularidades da constituição de uma comunidade judaica no Brasil, tanto em relação a outras comunidades étnicas ou religiosas que aqui se constituíram, quanto em relação às outras comunidades judaicas da diáspora. Pretendo indicar que o conceito de "comunidade judaica" (cj) é uma expressão forte, servindo efetivamente para entender o comportamento dos indivíduos que se consideram "judeus brasileiros" e, mesmo em parte, daqueles que têm uma ancestralidade judaica conhecida.

Sustento que a transformação da cj em uma instituição é o resultado de um processo social que constrange a formação da identidade judaica no Brasil: os judeus brasileiros obtêm vantagens na sua identificação como "judeus" e, mais tarde, como um "povo de intelectuais", resultado que facilita o despertar de vocações intelectuais nos membros da cj. Cria-se daí um espaço para a elaboração de teodicéias sofisticadas para a explicação do "que é ser judeu", coerentes com os produtos culturais mais legitimados do momento, tornando a identidade judaica mais manejável do que outras rubricas étnicas, culturais ou religiosas e assim, atraente para aqueles que poderiam reivindicá-la. Dessa forma, o "grupo potencial" judaico torna-se uma instituição ${ }^{2}$ no sentido mais estrito possível: a igualdade de condição é reconhecida por uma convenção cognitiva onde, do descendente de cristãos-novos até o recém chegado do Iêmen, todos consideram-se a si mesmos e aos outros como judeus ${ }^{3}$, ancorada num trunfo identitário diante da sociedade brasileira como um todo e fundada numa analogia com a natureza ou com a ordem sobrenatural (o sangue ou o privilégio diante de Deus comum, espalhado pela diáspora mas reunificado assim que as

\footnotetext{
${ }^{1}$ (DEP/UFSCAR/IDESP).

2 Sobre a utilização dos conceitos de "instituição" e "grupo potencial", ver M. Douglas (1986, p.46,7).

${ }^{3}$ Essa convenção obviamente não é automática, principalmente para a aceitação na cj dos cristãos-novos "retornados" ao judaísmo. Ver a respeito Ramagem (1991).
}

condições materiais de existência o permitiram). Procurarei sustentar esse ponto através de uma comparação entre as experiências judaica e armênia em terras brasileiras, enfocando aspectos do comportamento dos membros das duas comunidades na esfera política, econômica e intelectual.

Meus dados primários dizem respeito principalmente à inserção econômica dos armênios e à participação política dos judeus e dos armênios. Naturalmente, explorarei com mais intensidade esses dois mananciais, insistindo na dimensão cultural de cada uma dessas esferas.

Entre os 140 milhões de brasileiros, estima-se a existência de 25 mil descendentes de armênios no Brasil e de 150 mil indivíduos classificados como judeus. Os dois grupos concentram seus contingentes nas zonas urbanizadas das regiões mais industrializadas do país: os judeus nas principais capitais (estimando-se mais de 100 mil nas cidades de São Paulo e Rio de Janeiro) enquanto 90\% dos armênios residem nas cidades de São Paulo e Osasco.

Na sua generalidade internacional, judeus e armênios são duas etnias que possuem uma série de atributos comuns que justificam a comparação:

1) foram povos que mantiveram sua identidade durante séculos apesar de não dispor de um Estado nacional, que produz normalmente as condições de manutenção daquela característica;

2) viveram grande parte de sua história em ambientes onde as etnias majoritárias eram hostis;

3) por causa de disso, sofreram diversos massacres de maior ou menor magnitude, que ameaçaram a continuidade dos grupos, mas ambos conseguiram se recuperar dessas adversidades;

4) as conseqüências dos itens acima na esfera econômica foram importantes, conduzindo os membros de ambas as etnias a especializações funcionais nos diversos países em que seus membros viveram, que acabaram configurando-os como "povos negociantes" (middlemen). 


\section{As construções de generalidades "mainstream" do povo brasileiro}

Os estudos comparativos apontam esforços culturais que a quase totalidade das etnias que compõem o mosaico étnico nacional realizam. Os diversos grupos que estudamos constroem algum tipo de mito de origem que os coloca numa generalidade que une a etnia ao "mainstream" da sociedade brasileira (ou talvez mais precisamente, de suas elites), tal como eles a percebem.

Entre os judeus, podemos perceber uma enorme produção intelectual sobre a origem cristão-nova dos primeiros povoadores portugueses do Brasil, destinada aos mais variados mercados culturais ${ }^{4}$. Por sua vez, os armênios, com as limitações de acesso ao campo cultural brasileiro conforme analisarei adiante realça todos os pontos de seu arcabouço cultural que possam significar um caráter branco, ocidental e cristão para a etnia ${ }^{5}$. Em ambos os casos, estamos diante de operações simbólicas que visam suplantar os handicaps das comunidades, tal como elas percebem sua posição na sociedade brasileira.

Apesar do antijudaísmo ibérico histórico, a identificação de ancestrais judeus ou cristão-novos nas árvores genealógicas ou mesmo o casamento de seus filhos com judeus não parecem constituir problema para largas parcelas das elites brasileiras tradicionais (aparentemente, a origem cristão-nova é comparada a outra possibilidade menos enobrecedora: a descendência de antigos prisioneiros portugueses degredados para o Brasil. Falta, entretanto muita pesquisa nessa área). Por exemplo, o ex-presidente da República Fernando Collor de Mello, oriundo de família tradicional do Nordeste, afirmou várias vezes no decorrer da campanha eleitoral de 1989, que o elegeu presidente, que os Mello eram cristãos-novos. Já o atual presidente da República tem uma filha casada com um judeu, aliás, muito exposto à mídia ${ }^{6}$. Diante desses indícios podemos atribuir à grande produ-

${ }_{5}^{4}$ Examinei essa tendência em Grün (1994).

${ }^{5}$ Discuti essa tendência um Negócios \& famílias: Armênios em São Paulo. São Paulo: Editora Sumaré, 1992.

${ }^{6}$ A atividade político-eleitoral dos últimos anos vem adquirindo uma intensa profissionalização, no sentido de que, cada vez mais, os políticos do "mainstream" utilizam-se de instrumentos de marketing político, dentre os quais se destacam pesquisas qualitativas ção historiográfica dos judeus modernos sobre o papel dos judeus e cristãonovos na descoberta e povoamento do Brasil, um resultado de produzir e reiterar a crença na origem judaica de grande parte de suas classes dirigentes tradicionais, com as evidentes vantagens simbólicas advindas da identificação para os judeus brasileiros contemporâneos ${ }^{7}$.

Para entendermos esse aparente paradoxo, devemos lembrar algumas particularidades das formas simbólicas através das quais o povoamento das Américas e do Brasil em particular foram compreendidos, e de sua repercussão na estrutura social que se formou em terras brasileiras. No Brasil, assim como nos Estados Unidos, a ideologia oficial canta as vantagens do "cadinho de raças" como uma forma superior de constituição do povo brasileiro e, num segundo momento, da raça nacional. Esse imaginário inibe consideravelmente a possibilidade cognitiva de construção do judeu como demônio. Absorvendo indivíduos provenientes dos mais diversos cantos do planeta, estaríamos em condições de fazer valer as boas

diárias sobre o impacto de suas aparições na mídia, que ajudam os políticos a estabelecer e alternar suas estratégias de comunicação, principalmente em época de eleições. Caso o relacionamento com os judeus tivesse algum impacto negativo na opinião pública, certamente os políticos alterariam suas estratégias. Um caso interessante ocorreu recentemente, durante as eleições para o governo do estado do Paraná em 1994, estado que caracteriza-se por abrigar grandes comunidades de origem polonesa-cristã, alemã-oriental e ucraniana. Um dos contendores mais fortes era Jaime Lerner, político de origem judaica bem tipicada. A um mês da eleição, as pesquisas registravam um empate probabilístico entre ele e seu adversário principal, o então senador Álvaro Dias. Nesse momento, um pastor evangélico, candidato a deputado pela coligação de Álvaro Dias, lança acusações antisemitas contra Jaime Lerner, aparentemente tentando se beneficiar de um "anti-semitismo tradicional" dos paranaenses com ancestrais da Europa Oriental. Subitamente, o pleito regional ganha um grande espaço na mídia nacional, então praticamente tomada pela eleição presidencial. O fato coincidiu com a melhora relativa da posição de Lerner nas pesquisas, que culminou com a sua eleição e merece uma análise aprofundada. Sobre as possibilidades de uso político-eleitoral de preconceitos raciais arraigados na população, ver K. Jamieson. Dirty Politics: Deception, Distraction and Democracy. New York: Oxford University Press, 1992. O livro revela o "estado da arte" das tecnologias político-eleitorais, de conhecimento compartilhado entre os profissionais da área, que "ensinam a explorar os preconceitos" — é claro, em situações onde eles existiriam previamente.

7 Não estou dizendo que essa produção seja encomendada, apenas que ela é indiretamente incentivada, à medida em que ela "agrada a todos". Evidentemente, esse raciocínio não é rigoroso, constituindo-se numa hipótese que precisaria ser trabalhada não só na sua lógica interna, quanto na análise da relação entre as instituições judaicas contemporâneas do Brasil e a pauta de pesquisas sobre judeus e cristão-novos no Brasil colonial. 
características de cada raça, as quais se fundiram num todo harmonioso e superior aos traços originais de qualquer um de seus elementos constitutivos. Assim, onde a miscigenação racial é um objetivo a ser alcançado, não há muito espaço para a criação simbólica de uma "raça pura", de características intrinsecamente positivas, da qual os judeus deveriam ser apartados — primeiro simbolicamente, depois... - como portadores por excelência de más qualidades que conspurcariam contra a pureza desejada. A partir dessa linha mestra de pensamento, o único defeito inapelável da raça seria a sua eventual incapacidade de fundir-se ${ }^{8}$ no "mainstream" da população - justamente o contrário do que a ideologia anti-semita européia reprochava dos judeus ${ }^{9}$. Essa particularidade foi importante, contribuindo para impedir o sucesso da agitação anti-semita importada da Europa no Brasil.

Investigando a formação da identidade étnica armênia no Brasil, deparei-me com um discurso estereotipado dos líderes da etnia, no sentido de referendar suas pretensões de ocidentalidade. Ao tentar entender a insistência nesse tópico, descobri espantado o quanto ainda pesa para os membros do grupo a descrição/impugnação que eles sofreram na década de 1930 por parte dos intelectuais proeminentes ligados ao governo brasileiro da época. Por exemplo, os livros escolares de história armênia em uso no Brasil $^{10}$ fornecem repetidas evidências no sentido da afirmação da brancura da raça. Trata-se de uma narrativa histórica onde sempre os armênios se aliavam com nações ocidentais contra os orientais — com as cruzadas contra os turcos, árabes e bizantinos; com os bizantinos ${ }^{11}$ contra os turcos

\footnotetext{
${ }^{8}$ Como se pode prever, o processo de imigração gerou multa polêmica no seio das "classes cultivadas" brasileiras. Toda imigração branca era em geral bem vista, já que contribuiria para o branqueamento da população brasileira, objetivo considerado estratégico para o desenvolvimento do país. Mas, à medida que se considerava que uma determinada "raça" tinha pouca propensão a diluir-se através dos casamentos interétnicos, ela era considerada indesejada. Obviamente, essa acusação era proferida conta os judeus, mas o era coar muito maior intensidade contra os japoneses e, numa situação intermediária, contra os sírios e libaneses. A peculiaridade levantada na nota anterior certamente agiu em prol dos judeus. 9 Lembremos que, para os nazistas, os judeus deveriam ser exterminados justamente porque para eles, seria impossível manter a raça ariana imune aos casamentos cristos conseqüentemente, a permanência dos judeus em território alemão acabaria por produzir unia descendência miscigenada e a gradual degenerescência da raça germânica.

${ }^{10}$ Sapsezian (1988); "História de meus antepassados", sem autor. 1980.
}

${ }^{11}$ Notemos a sofisticação relacional: no primeiro caso, os cruzados eram mais ocidentais do no século XV — sempre registrando a nação armênia couro um bastião avançado da ocidentalidade, lutando contra as sucessivas hordas de orientais (árabes, mongóis, turcos, alanos, curdos etc.). Assim, uma vez no Brasil, um país do Ocidente, os armênios apresentam-se como unia etnia legítima e heroicamente ocidental ${ }^{12}$. Reforçando esta impressão, lemos num panteão de heróis nacionais para uso escolar que: "Dikran II, o Grande (9555 a.C.) era um formoso jovem louro, de olhos azuis". E essa é a única descrição física detalhada de um personagem da história que aparece rio livro $^{13}$. É interessante contrapor a descrição do herói armênio à descrição e as categorias empregadas por Oliveira Vianna (1940), quando este intelectual, que gozava de legitimidade científica e política, apreciava a possível contribuição dos imigrantes vindos do Oriente Médio para a constituição racial do povo brasileiro:

Os imigrantes turcos-árabes formam uma colônia numerosíssima [...] Do ponto de vista antropológico, esse grupo e muito heterogêneo. Nele, os elementos preponderantes são armênios. Ora, os armênios (ao menos os armênios imigrantes) são indivíduos que Kossovitch descreve como de tipo acentuadamente braquicéfalo, de estatura abaixo da média $(1,62)$, de pigmentação mate da pele, de cabelos brunos com reflexos amarelados ou avermelhados, de olhos geralmente escuros e, só muito raramente, azuis ou verdes ${ }^{14}$ (p. 610$611)$.

que os bizantinos; no segundo, os bizantinos eram mais ocidentais do que os turcos. Registremos, por outro lado, que os livros eram traduções de obras produzidas em países mais importantes da diáspora armênia, como os Estados Unidos, a trança e a Argentina. Mas dada a internacionalidade da pregação eugenista, podemos avançar que a etnia armênia devia travar combates simbólicos análogos naqueles países.

${ }^{12}$ Um livro de história da Armênia (Artzruni, 1976, traduzido e editado pela colônia no Brasil teta a seguinte primeira frase: "No grande duelo que se travava entre a Europa e Ásia, havia a Armênia tomado partido pela civilização européia ou, como se dizia então, pela cristandade").

13 "História de nossos antepassados", s.a.; s.d.; Edição da Comunidade Armênia de São Paulo.

${ }^{14}$ Notemos que Oliveira Vianna está falando de tipos físicos e não de una etnia agrupada em torno de uma herança cultural comum. Mas, segundo a abordagens vigente a época, as características culturais de um povo poderiam ser derivadas de suas particularidades físicas. 


\section{História da imigração e produção das identidades étnicas}

No Brasil, a explicação da reconstrução da identidade étnica dos dois grupos terá de ser matizada pelas histórias peculiares de cada um dos processos de imigração. Os armênios chegaram ao Brasil em duas levas bem tipificadas. A primeira delas foi no fim do século XIX, quando um pequeno grupo de armênios seguiu a grande corrente migratória síria e libanesa ${ }^{15}$. Esse contingente era constituído principalmente de armênios oriundos da chamada "Armênia Oriental”, então uma província do Império Russo. O pequeno tamanho dessa primeira leva impedia a criação de órgãos comunitários, tanto leigos como privados, de sorte que as atividades comuns do grupo (casamentos, cerimônias religiosas) eram realizadas em residências particulares. $\mathrm{O}$ segundo momento, numericamente muito mais importante, pode ser localizado em torno do ano de 1924, quando o Brasil, seguindo um acordo estabelecido com a Liga das Nações, acolheu um contingente de armênios que haviam sido deslocados de sua região de origem - a chamada Cilícia, região que corresponde ao norte da Síria e sul da Turquia atuais - em decorrência dos massacres de 1915. Grande parte desse grupo era composto de crianças e jovens órfãos que estavam estacionados em diversos campos de refugiados e orfanatos dirigidos pela Liga ou por organizações filantrópicas leigas e confessionais. Importa aqui ressaltar que essa massa humana estava privada das fontes normais de socialização étnica - além de a maior parte dos empreendimentos humanitários ser dirigida por Igrejas cristãs de rito não-armênio, o alvo prioritário dos massacres de 1915 foram justamente os membros intelectuais e letrados da comunidade armênia.

Quando os refugiados chegaram ao Brasil, a sua enorme maioria não falava nem a língua de seus antepassados e nem tampouco praticava a sua religião. Normalmente, eles se expressavam em turco, a língua de seus opressores, e não tiveram oportunidade de obter uma educação religiosa considerada satisfatória pelas Igrejas de ritual armênio. Diante do fluxo de novos imigrantes, os membros abastados da primeira leva impulsionam a constituição de diversos órgãos comunitários, hospedarias de acolhida, escolas e, principalmente, igrejas. Durante o estabelecimento da prática religiosa foram chamados alguns sacerdotes da Igreja Apostólica Armênia,

\footnotetext{
${ }^{15}$ Ver Truzzi (1991)
}

formados nos seus locais tradicionais de preparação de clérigos - Armênia Oriental, Jerusalém, Istambul para os apostólicos e Roma para os católicos de rito armênio - que cumpriram o papel tanto de guias religiosos, quanto de autoridades intelectuais da comunidade nascente, contribuindo para estabelecer o conhecimento da língua e cultura do grupo no Brasil. Conforme veremos adiante, essa peculiaridade será responsável por uma assimetria nas relações do grupo com a sua cultura étnica, que produzirá efeitos não negligenciáveis na vivência armênia em terras brasileiras.

\section{A esfera econômica}

No capítulo econômico, podemos notar uma forte especialização funcional do grupo étnico no ramo de calçados. A criação do nicho econômico coloca-nos diante de uma cadeia causal interessante, onde os fatores econômicos e culturais se entre-alimentam. No nicho de inserção profissional dominado pelos armênios, a questão da identidade racial ganhará contornos econômicos explícitos, que retroalimentarão a trama especificamente simbólica. A explicação da especialização irá mobilizar o imaginário coletivo, gerando uma tensão entre um mito de origem artesanal e a prosaica exploração de uma oportunidade comercial.

Obtivemos diferentes explicações sobre as causas da inserção dos armênios no ramo dos calçados. Este "mistério" pode ser esclarecido pela análise das formas de entre-ajuda praticadas na colônia, que induzem os seus beneficiários a manter e desenvolver a permanência no ramo dos calçados. De um lado, os entrevistados afirmavam, com maior ou menor convicção, que seus ancestrais tinham vindo da província de Marash, onde os armênios tinham a fama de serem os melhores artesãos em couro. Esse mito de origem foi enunciado com maior ênfase, não por acaso, por uma autoridade religiosa, por unia agente inserida no segmento de alto luxo da produção e da distribuição de calçados femininos e por um dos poucos descendentes de armênios que se mantém na indústria de calçados.

A literatura científica sobre imigração tende a mostrar que a maioria dos casos de especialização surge do aproveitamento de oportunidades os vazios na estrutura econômica - abertas no país ele destino, que são 
rapidamente preenchidas pelos membros ele uma determinada etnia através da entre - ajuda. Desta forma, "desencantam-se" as explicações indígenas, mostrando a "falsidade" dos argumentos ${ }^{16}$, O problema é que este estilo de análise deixa de lado a dimensão subjetiva da especialização. Os mitos de origem transmitem-se entre as gerações através de investimentos afetivos que se inscrevem de modo durável na personalidade dos agentes como identidades e assim acabem tornando-se propriedades sociais relevantes, capazes de explicar e predizer comportamentos, entre os quais, a escolha do locus de inserção econômica.

Estamos diante de construções de identidade que pouco devem ao acaso, onde os agentes manejam seletivamente as suas lembranças, de acordo com as suas posições nas esferas onde atuam: cultural-religiosa, calçadista e outras. O repertório de possibilidades dos agentes é acionado naturalmente no sentido da construção de identidades que referendem sua posição atual ou ambições. Mas, muito mais relevante do que buscar as intenções dos agentes quando eles se atribuem determinada origem, é saber se as identidades propostas "colam", atribuindo aos agentes as qualidades correspondentes, tanto aos seus olhos como aos dos consumidores e concorrentes e, desta forma, fixando uma expectativa e um padrão de comportamento $^{17}$.

No esquema da auto-ajuda, os armênios já estabelecidos empregavam seus conterrâneos menos favorecidos nos seus negócios, que aproveitavam a oportunidade para conhecer os meandros do ofício e, quando condições favoráveis se apresentassem, estabelecer-se por conta própria. Nesse

\footnotetext{
${ }^{16}$ Para um "estado da arte" sobre a produção da área, ver Waldinger et allii (1690).

${ }^{17}$ É verdade que a relação entre o pesquisador e os pesquisados não se resolve coar este nosso artifício "escolástico". Os pesquisados têm todo o interesse do mundo cor que o pesquisador referente- dando veracidade científica - às suas pretensões de origem. Seria assim bastante possível o uso posterior, por parte dos armênios engajados no setor de calçados, de uma "pesquisa científica realizada no IDESP" (Instituto de Estudos Econômicos, Sociais e Políticos), que mostraria o papel proeminente e a vocação dos armênios para o rumo. É claro que não Podemos reivindicar o controle sobre os usos e efeitos dos trabalhos de reconstrução das epopéias imigrantes, mas o registro deve ser feito para lembrarmos que esse tipo de trabalho acaba interferindo na realidade que ele tenta dar conta da mesura maneira que os esforços anteriores dos intelectuais das colônias, servindo como um eventual subsídio para que os descendentes de imigrantes localizem-se e referendem sua posição no espaço social.
}

sentido aparece a interpretação, corrente ainda hoje na colônia, de que "o armênio não serve para ser empregado". Esta condição seria um mero momento na sua carreira social, que se encaminhava naturalmente para a sapataria própria. O período de trabalho assalariado era uma espécie de adolescência social no sentido de Duby (1964). Ele funcionava como um período de experiência, onde o negociante em potencial aprendia as lides do ramo calçadista, ao mesmo tempo em que provava o valor de sua personalidade de "bole armênio", qualificando-se como receptor da ajuda de seus conterrâneos, para daí estabelecer-se por conta própria no ramo.

O processo enunciado acima pode ser considerado uri excelente produtor e reprodutor de identidades étnicas. A homologação do indivíduo com direito a se estabelecer por conta própria dá-se através de uma avaliação total da sua personalidade, onde não aparece nenhuma característica objetiva, claramente definida. Além de hábil comerciante ou industrial, ele deve ser também considerado confiável como receptor de créditos em dinheiro e em matérias-primas. Por se tratar de um espaço onde o que conta é o "fio do bigode" e onde os outorgados não possuem propriedades materiais para avalizar seus débitos, essa avaliação é impiedosa. O candidato ao crédito deve portanto parecer ao máximo um semelhante do outorgante. Como aquele não tem outra fonte de aprovisionamento, podemos imaginar os seus esforços para conquistar a simpatia dos eventuais benfeitores.

As formas de entre-ajuda que conduziram especificamente à especialização funcional, produziram também, indiretamente, a afirmação da identidade étnica em geral. Esta conexão leva-nos ao centro da problemática da não-dissociação entre a esfera econômica e as esferas religiosa e cultural nas estratégias de carreira dos imigrantes e descendentes de primeira geração. Numa colônia pequena, onde o papel da Igreja é fundamental na vivência em comum, cria-se então uma rede, onde o trunfo inicial do armênio recém-chegado, desprovido de recursos materiais, só tinha valor no mercado de sapatos, à medida em que a entre-ajuda era "dedicada", uma espécie de adiantamento de capital apenas aplicável na confecção e venda de sapatos. A especialização dos agentes das primeiras levas acabava criando uma massa crítica, onde os armênios iam se estabelecendo e muitos prosperando, num processo que potenciava cada vez mais a construção da identidade étnica. 
Para nossa comparação, a não-diferenciação entre as esferas econômica e cultural na rede comunitária tem efeitos importantes: na sua auto-representação, os armênios brasileiros são aquilo que eles fazem, e o que eles fazem é centralmente uma atividade econômica. $\mathrm{O}$ seu valor perante a sociedade brasileira mede-se pelo seu sucesso econômico. Não por acaso, nossos informantes listam os membros mais proeminentes da comunidade a partir de uri princípio hierarquizador de fundo econômico: seus "grandes" são os donos das mais importantes cadeias de comercialização de calçados, os banqueiros, os construtores e o "sócio do Silvio Santos" 18 .

\section{Os judeus nas confecções}

Entre os judeus, a especialização étnica deu-se no ramo das confecções. A literatura evoca constantemente a qualidade transoceânica dessa característica econômica. Os judeus brasileiros teriam chegado da Europa Oriental já dispondo de uma competência em alfaiataria, que refletiria a especialização do grupo no antigo Império Czarista. Chegando no Brasil, eles teriam encontrado um campo fértil para se desenvolver nos espaços econômicos vazios da sociedade.

Como analisamos para o caso armênio, é possível que a reivindicação tenha fundamento, mas ela deve ser atenuada. A imigração judaica para o Brasil teve fluxos bem diferentes da armênia. Ela se desenvolveu como uma corrente praticamente contínua a partir do fim do século XIX até os anos 1960, envolvendo judeus de diversas origens e backgrounds. Apesar disso, grande parte dos recém-chegados acabou estabelecendo-se e ampliando o nicho que seus antecessores já haviam escavado. A maior magnitude do contingente, a heterogeneidade de origem e de distribuição de faixas etárias tornam muito mais difícil unia análise de rede que pudesse fazer-nos chegar ao "primeiro núcleo de judeus confeccionistas", a partir do qual a

\footnotetext{
${ }^{18}$ Poderíamos anotar uma história análoga para a odisséia síria e libanesa em terras brasileiras, aonde a comunidade constrói uma ancestralidade fenícia (portanto, diferente da árabe) para suas origens, explicando assine "geneticamente" sua vocação comercial. Ver a respeito Truzzi, 1991.
}

especialização teria se irradiado ${ }^{19}$ (se é que ele existiu realmente).

Mas, se para os armênios estabelecidos em terras brasileiras a especialização funcional centraliza a formação de identidade, o repertório cultural dos judeus acabou buscando unia teodicéia baseada na alta cultura. Quando entrevistamos membros da comunidade ${ }^{20}$, mesmo distantes da vida intelectual, sempre aparece uma visão do "povo judeu como um povo de sábios e intelectuais", de extrema funcionalidade, se pensarmos na necessidade de lidar com o eterno problema do anti-semitismo. É claro que essa auto-identificação não tem correspondência direta com as "condições de vida objetivas" da etnia no Brasil, mas ela pressiona os seus membros, abrindo espaços simbólicos importantes nas estratégias de reprodução social do grupo ${ }^{21}$. O repertório "judeu é intelectual" permite aos membros das novas gerações o vislumbre e, por efeito da agregação de chances, o engajamento efetivo em profissões intelectuais, constrangendo as possibilidades de argumentação dos pais/comerciantes (que normalmente iriam pressionar sua descendência no sentido de perpetuar as atividades empresariais das famílias) durante os contenciosos intergeracionais que irão decidir o futuro das famílias. O resultado agregado da existência dessa possibilidade é a formação de grupos significativos de intelectuais leigos judeus, os quais, por sua vez, acabaram por se tornar um trunfo tão mais importante quanto pouco conhecido da comunidade judaica do Brasil. Direta ou indiretamente, o resultado agregado dos diversos trabalhos de elaboração de sua identidade que esse estrato realiza rebatem na comunidade judaica como um todo, permitindo-lhe produzir uma autoimagem adequada para o universo simbólico atual.

Esse resultado fica magnificado justamente pelo contraste do grupo judeu com o armênio: como vimos, a formação do grupo que zela pela continuidade da cultura e religião armênia no Brasil é perpetrada por religiosos formados nos centros mundiais de cultivo das tradições da etnia.

\footnotetext{
${ }^{19}$ Ver a tabela 1 no apêndice para os dados disponíveis sobre a origem da imigração judaica para o Brasil, durante os seus anos de maior intensidade.

${ }^{20}$ Entrevistamos políticos de origem judaica e líderes de organizações comunitárias que se relacionam com as atividades da esfera pública.

${ }^{21}$ A tabela 2 no apêndice mostra os dados disponíveis sobre a distribuição profissional dos judeus no estado (de São Paulo em 1968. Trata-se de dados de um censo comunitário que pode esconder unia variabilidade importante.
} 
Esse estrato tem sua firmação intelectual ditada por uma lógica interna à comunidade armênia internacional, fornecendo para os armênios leigos interpretações do mundo ditadas por sua inserção no campo religioso e no campo do poder da diáspora. Podemos ver o efeito dessa peculiaridade através das interpretações dadas ao holocausto perpetrado contra os armênios em 1915 e na relação que a comunidade mantém cora os políticos que dela são oriundos, duas questões que são básicas para a formação da identidade da etnia:

\section{A questão do Holocausto sofrido pelos armênios}

O grupo reivindica, com muita dificuldade, o reconhecimento internacional do acontecimento ${ }^{22}$. Quando entrevistamos os membros da comunidade e pesquisamos seus materiais de referência, encontramos uma elaboração substancialista a respeito dos massacres de 1915, refletindo um estágio passado do campo científico das ciências humanas e biológicas, o que impede que ela obtenha repercussões externas à comunidade em grau análogo aos resultados práticos obtidos pelos judeus na "rentabilização" do Holocausto levado a cabo pelos nazistas. No Brasil, o livro mais importante dedicado à descrição dos massacres sofridos pelos armênios, vendido nas organizações comunitárias armênias em São Paulo, assim descreve os curdos, que repovoaram — a mando das autoridades otomanas — as regiões anteriormente ocupadas pelos armênios: "Tribos muçulmanas da Anatólia Oriental; habitante do Curdistão. Os curdos vivem em tribos e sua civilização é do tipo interior" (Kerimian, 1981, p. 268). É importante ressaltarmos que não se trata da elaboração cotidiana do membro "médio" da comunidade. Nesse nível, certamente encontraremos também elaborações judaicas substancialistas, considerando que o Holocausto nazista foi obra de um "povo alemão intrinsecamente mau". Mas o decisivo é que, para o grupo judeu, esse tipo de argumentação, insustentável de acordo com a norma culta, não atinge a esfera pública. Aí, o estrato intelectual leigo acaba dando uma forma erudita moderna às perseguições

${ }^{22} \mathrm{O}$ recente processo que a comunidade armênia francesa moveu contra o historiador Bernard Lewis é só mais um passo no trabalho - a meu ver de Sísifo - de fazer o mundo registrar o evento. sofrida pela etnia, culpando os nazistas e não os alemães indistintamente. Como, ao contrário da argumentação armênia, essa última consegue ser legitimada nos padrões culturais do momento, ela ganha espaço na arena pública, aparecendo naturalmente como uma espécie de crédito que os dirigentes da comunidade judaica podem utilizar nos mais diversos contextos.

Insisto que não se trata de nenhuma análise substancialista da cultura das duas etnias, mas simplesmente uma questão de controle e gestão da imagem pública, onde as circunstâncias históricas acabaram favorecendo durante algum tempo a comunidade judaica, mas que não tem nada de garantidas ou perenes. É assim que, no momento em que escrevo esse texto, temos material para dar nuance e precisar o argumento: do lado judaico, está ganhando muita aceitação nos EUA e Grã-Bretanha um livro ${ }^{23}$ sobre o Holocausto, escrito por um acadêmico, que propõe uma explicação daquele acontecimento como um fenômeno onde a quase totalidade dos alemães não judeus teriam tomado parte, direta ou indiretamente. Um estudo sobre a "carreira" futura desse livro e de seu autor poderia ajudar a nuançar a hipótese que formulo e dizer muito sobre as suas condições de validade.

Por outro lado, o governo da recém-independente República Armênia, formado em grande parte por intelectuais leigos de formação humanista, insiste na necessidade de preparar emocionalmente os armênios para unia espécie de desarmamento espiritual, necessário para conviver numa região geográfica onde os vizinhos mais próximos são na sua quase totalidade muçulmanos e de "origem turca", como os azerbaijanos. Essa predisposição conflita com a chamada "demonização dos turcos", que virou uma espécie de mito fundador da diáspora armênia no Ocidente. ${ }^{24}$ Assim,

${ }^{23}$ Hitler's Willing Executioners: Ordinary Germans and the Holocaust, de Daniel Goldhagen, Little, Brown. O livro, que parece sustentar uma tese desacreditada pelo establishment de estudos sobre o Holocausto, ao ser lançado justamente na época do ano em que os periódicos procuram material para registrar o fim da Segunda Guerra Mundial na Europa, ganhou várias resenhas. Recém-saído na GB e nos EUA (abril de 1996), já se anuncia uma próxima edição brasileira, pela Companhia das Letras (Folha de São Paulo, 12.05.96, pp. 54; 5-5), além de referências elogiosas em órgãos da comunidade (p.ex. "Nazismo Nunca Mais, de C. Gurfinkel, em Resenha Judaica, $1^{\text {a }}$ quinzena de julho 1996, p.11).

${ }^{24}$ Ver a respeito "Six to Eight Characters in Search of Armenian Civil Society amidst the Carnivalization of History", de M.M. Fischer \& S. Grigoriam, in G. Marcus (ed.). Perilous States: Conversations on Culture, Politics, and Nation, Chicago University Press, 1993, p. 
uma análise da política do atual governo armênio sugere que

a filosofia do Movimento "Toda a Armênia", especialmente sob a liderança de Levon Ter-Petrossian, deliberadamente recusa a centralidade simbólica do simbolismo nacionalista que alimentou o nacionalismo da diáspora nos últimos setenta anos. Isso significa uma recusa em fetichizar as antigas demandas de um reconhecimento internacional da acusação de genocídio sobre os otomanos ou jovens turcos...

Observar a evolução desse "contencioso cultural", onde a tendência mais provável é de o estrato intelectual à frente da República Armênia produzir artefatos culturais que dêem conta dos massacres segundo a norma culta e a concorrência também previsível desses produtos com as interpretações correntes na diáspora, patrocinadas pelos seus intelectuais religiosos tradicionais é uma questão de extremo interesse para o prosseguimento da pesquisa ${ }^{25}$. Mesmo com o poder temporal controlando a hierarquia religiosa no interior da Armênia, o peso da diáspora, afinal construída em grande parte em torno da celebração do holocausto, é desproporcionalmente grande, dadas as condições econômicas desesperadoras por que passa a sua recém-criada república.

\section{A participação de membros das duas etnias na esfera política}

Investigando as carreiras e os padrões de atuação de políticos oriundos das duas etnias no estado de São Paulo, podemos ver o contraste a partir de outro ponto de vista. Enquanto os vereadores e deputados de

81-130.

${ }^{25}$ Significativamente, assinala-se que o último Patriarca da Igreja Armênia - que congrega 85\% dos descendentes de armênios no Brasil — sagrado em 1993, conseguiu sua indicação através da forte pressão sobre o Colégio Eleitoral exercida pelo presidente da República Armênia, o etnólogo Lev Ter-Petrossian. Ainda não sentimos nenhuma mudança de atitude na comunidade armênia brasileira em relação a esses acontecimentos, mas os materiais culturais que ela usa, lhe chegam através das comunidades armênias francesa, norteamericana e argentina, bens mais expressivas numericamente. Ver a respeito: Iskandaryan, A. "Armenia: In the Election of the Head of the Armenian Church the Winner is Garegin II, President Ter-Petrosyan's protegé”. In: New Times, 01.06.95, p. 44. origem armênia agem no campo político como "freeriders", os seus êmulos judeus obedecem outro padrão: eles começam suas carreiras corno "candidatos independentes" (da comunidade judaica), situando-se na sua maioria na faixa esquerda do espectro político brasileiro e, conforme suas trajetórias se desenvolvem, eles se tornam cada vez mais dependentes da comunidade, seja em votos, seja em patrocínio, ou mesmo no estabelecimento de suas agendas. A diferença nos padrões de atuação acabará influindo na imagem das comunidades diante da sociedade brasileira, contribuindo para conferir aos judeus a identidade a que nos referimos acima, diferente daquela registrada para os armênios.

Uma primeira explicação para essas diferenças reside no recrutamento dos políticos: os armênios que entrevistamos eram filhos de grandes empresários que, "colocando o filho na política", resolviam, ao menos provisoriamente, conflitos na gestão e sucessão dos negócios familiares $^{26}$. O apoio à postulação política de um filho era considerado uma compensação razoável para o seu afastamento da direção da empresa. Evidentemente, a socialização desses "filhos de nababos" tenderia a fazêlos encaixar-se mais naturalmente no papel de empresários. Não é assim por acaso que vemos muitos políticos dessa origem agirem de forma a tentar estender as regras de funcionamento do universo empresarial onde foram criados para a esfera política. Ora, a incompatibilidade com a "cidade mercantil" é mia condição prévia para o bons funcionamento da "cidade cívica", o mundo onde a política adquire a sua maior expressão e legitimidade social (Boltanski \& Thevenot, 1991, p. 318-9). Assim, a

26 Estamos falando principalmente de Ubirajara Keutenedjian (ver nota 23, infra). Informações complementares que obtivemos junto a antigos parceiros econômicos de Varam Keutenedjian dão conta de unia imensa quantidade de recursos empregada nas sucessivas eleições de seu filho, que seriam responsáveis pela descapitalização da empresa. O outro grande político armênio da época, Carlos Kherlakian, que não conseguimos entrevistar, parece ter percorrido um caminho análogo. O conflito pelo controle acionário da Eucatex, empresa controlada pela família do político de origem libanesa Paulo Maluf, opondo o líder da direita paulista e o resto de sua família, personificada pela mãe D. Maria e seu irmão Roberto, parece ilustrar o mesmo princípio. O único "judeu de família de nababos" que encontramos foi Horácio Lafer (1900-65), que constituiu-se num importante líder empresarial, chegando a ministro da fazenda na presidência constitucional de Vargas (19504). 1) diferentemente de seus concorrentes de origem árabe ou armênia, ele expressava posições econômicas austeras, análogas — mutatis mutandi — àquelas dos conselheiros judeus do Kaiser Guilherme II. 
atuação desse gênero de políticos, que obviamente transcende o universo étnico de que estamos tratando, ajuda a referendar as mais impiedosas caracterizações do campo político como "um mercado", numa espécie de denúncia constante da atividade política como a busca de interesses pessoais numa arena onde deveriam prevalecer os interesses maiores da coletividade. Sem dúvida, esta é unia das principais fontes de alimentação do humor antipolítico existente na sociedade brasileira.

Pelo que pudemos constatar, nossos entrevistados judeus não dispunham de background familiar parecido com os seus concorrentes das outras "etnias comerciantes"27. Pelo contrário, eles parecem políticos "selfmade", que vivem $d a$ política porque vivem para a política, jogando neste campo todas as suas cartas (Bourdieu, 1989). Mas essa variável isolada também não explica a situação. As biografias dos primeiros políticos nikkei - descendentes de japoneses - em São Paulo também registra jovens bacharéis de origem não abastada, igualmente com poucas chances de adentrar nas corporações do Estado, mas postulando candidaturas nos partidos do oficialismo e da direita do espectro, além de serem nitidamente incentivados pelos órgãos de representação do governo japonês no Brasil ${ }^{28}$.

Minha hipótese para explicar a singularidade do posicionamento dos judeus no campo político é que as necessidades internalizadas da luta contra o preconceito restringem a possibilidade do aparecimento de empresários da política na colônia. Diante do quadro de constrangimentos carregado pela etnia judaica em todo o mundo ocidental, a eles não é permitido transformar o dinheiro em moeda para fora da esfera econômica sem o enorme risco de reitera o preconceito do judeu ávido, cuja única preocupação e escala é o dinheiro. Se por ventura, algum ator isolado ensaia algum passo nessa direção, ele é rapidamente "enquadrado" pela comunidade, ou deixa-a. Pelo contrário, o dinheiro judaico deve ser enobrecido pela adesão de seu possuidor aos valores mais altos da cultura. Essa tendência atinge o

${ }^{27}$ A nossa entrada no universo de pesquisa judeu foi diferente da obtida na comunidade armênia, o que pode explicar parte das diferenças. Conhecendo previamente pelo menos parte do relevo estrutural judaico, fui a campo com unia idéia pré-concebida do que iria encontrar. Já entre os armênios, realizei duas bolas de neve a partir da representação oficial da colônia

${ }^{28}$ Ver C. Sakurai: "A Fase Romântica da Política: os Primeiros Deputados Nisseis no Brasil”. In: Fausto et alii, 1995. paroxismo quando os judeus modernos enfrentam situações de forte preconceito anti-semita. São emblemáticas nesta rubrica as situações enfrentadas pelos judeus na Áustria e na Alemanha do entre-guerras, onde podemos explicar a adesão total dos intelectuais judeus aos valores específicos do campo intelectual, a adesão total dos políticos judeus aos valores do campo político por esta tendência ${ }^{29}$.

Não é assim por acaso que vimos dois grandes empresários judeus José Mindlin e Max Feffer — se sucederem na pasta de secretário da cultura do governador paulista Paulo Egydio Martins na década de 1970. Em torno desse cargo, em geral considerado "decorativo" pelos políticos de outra origem étnica, mas altamente emblemático para os judeus, acaba se criando uma imagem, principalmente na direita do espectro político, de que ele é "para os judeus", e assim, em São Paulo, ele acaba virando, para atores como Jânio Quadros ou Paulo Maluf, um instrumento de aproximação com a comunidade judaica ${ }^{30}$.

A comparação esboçada com os políticos de origem armênia, que pode também ser estendida aos descendentes de sírios e libaneses, as etnias mais próximas dos judeus em termos de inserção socioeconômica típica, oferece-nos uma boa medida brasileira para esse fenômeno que acredito ter alcance bastante amplo. Enquanto os judeus recorriam aos partidos "de esquerda", os candidatos de outras etnias "comerciantes", sírios, libaneses e armênios, lidavam com a questão da oferta de legendas de outra forma. Eles procuravam partidos menos expressivos ou pouco caracterizados por posições ideológicas claras. Um entrevistado de origem armênia, deputado estadual por duas legislaturas e federal por uma durante a década de 1950 e início dos 60, disse-nos mesmo que: "cansado de ter de comprar legenda em todas as eleições, ele acabou 'comprando' um partido e invertendo o

\footnotetext{
${ }^{29}$ Ver a respeito a coletânea "Jews, Anti-semitism and Culture in Vienna", Oxaal, 1987. No mesmo sentido pode ser avaliada a reação puramente intelectual dos intelectuais judeus alemães — e dos judeus em geral — face ao recrudescimento do anti-semitismo no início do século XX, até a instalação definitiva do nazismo (Bachartch, 1980).

${ }^{30}$ No caso do prefeito Jânio Quadros (1988-9), esse político "oferece" aos judeus a Secretaria da cultura, causando celeuma na comunidade. Da mesma forma, o atual prefeito Paulo Maluf entroniza na mesma pasta Rodolfo Konder que se considera, e é por muitos judeus também considerado, um "judeu honorário", com participação destacada em eventos da colônia.
} 
processo, tornando-se um 'atacadista de legendas'. Sobra-nos assim um resíduo inexplicável pelas leis mais prosaicas da interação entre oferta e demanda de espaços na arena política.

No campo político, o recurso ao repertório anti-semita parece uma arma recorrente dos adversários de qualquer candidato judeu. Nossos entrevistados "de esquerda" falam desse tema de maneira quase automática, como se a denúncia do anti-semitismo fosse parcela integrante da denúncia das mazelas do capitalismo em geral, o que não é surpresa. Mais interessante é notar que também os "direitistas" apontam o anti-semitismo como um recurso comum de seus concorrentes goyim (gentios, ou não judeus), os quais, em geral, situam-se à esquerda do espectro político. Assim, um político atualmente filiado ao Partido Trabalhista Brasileiro, situado à direita do espectro político regional com base eleitoral no $\mathrm{ABC}$ paulista (cidades de Santo André, São Bernardo e São Caetano, subúrbios de São Paulo), principal zona de influência do Partido dos Trabalhadores, que por sua vez situa-se na extrema esquerda do espaço, informa-nos que seus adversários regionais referem-se a ele nas campanhas como um "judeu capitalista", mobilizando desta forma a tradicional mistura de sentimento anticapitalista com o anti-semitismo ${ }^{31}$. Os entrevistados de origem armênia também queixam-se de xenofobia. Esse gravame é mais significativo, pois nossos entrevistados daquela origem situavam-se todos à direita do espaço das posições possíveis no campo político brasileiro. Em ambos os casos armênio e judeu - o momento forte do desvelamento do sentimento antiimigrante situou-se nos períodos mais autoritários do regime militar de 1964-1985.

Mas, o que diferencia decisivamente a experiência dos dois grupos na esfera política é ação de cada uma das comunidades, como instituição ${ }^{32}$,

\footnotetext{
31 Estou reproduzindo apenas a versão dada pelo depoente. É bom lembrar que a sensibilidade judaica ao repertório anti-semita é extrema. Dessa forma, qualquer referência que possa lembrar o anti-semitismo pode ser amplificada pelos filtros do entrevistado, bem como, mais prosaicamente, pela vontade de gerar simpatia à sua causa na colônia, mobilizando uma expectativa muito disseminada na colônia judaica, de que os petiscas tenderiam a ser anti-semitas, já que apoiariam a OLP (Organização para a Libertação da Palestina).

${ }^{32}$ Penso aqui na idéia de comunidade ou instituição como "representação coletiva", no sentido dado à essa expressão na Sociologia de Durkheim e aprofundado por M. Douglas
}

sobre as carreiras individuais. Notamos claramente que os políticos de origem judia tornam-se políticos judeus no decorrer de suas carreiras, fato que não ocorre de maneira nenhuma com seus colegas de origem armênia em relação à sua comunidade de origem. Isto é, a comunidade judaica age como uma espécie de magneto, atraindo os homens políticos que dela se originaram, oferecendo uma rede de apoios - tanto votos propriamente ditos quanto patrocínio material e simpatia — e cobrando de seus representantes na esfera pública a apresentação de uma determinada imagem, compatível com aquela que ela (comunidade) se imagina. $\mathrm{Na}$ experiência política brasileira, essa situação só encontra paralelo na comunidade de origem japonesa, embora com as nuances que relatei acima. Acredito que o estudo da ação desse agente coletivo sobre os membros individuais da comunidade judaica é um dos pontos principais por onde devem caminhar os estudos judaicos.

Mas, tudo que é sólido desmancha no ar. O rearmamento ideológico das direitas, propiciado pelo neoliberalismo, irá alterar nosso contexto. Agora, existe uma direita libertária, no sentido de que considera a esfera privada um ambiente que deve ser protegido da intervenção do Estado. De um lado, a associação "direita e fascismo e anti-semitismo", antes verossímil, funciona cada vez menos nos cenários político e cultural. Dessa maneira, a impugnação sofrida anteriormente pelos políticos de origem judaica que se aventuravam na seara da direita brasileira perde progressivamente a eficácia, apontando e refletindo uma situação onde o fantasma do anti-semitismo parece conjurado. Mas, mesmo com esse senão, podemos encontrar um novo padrão que atualiza o repertório "judeu é de esquerda": trata-se da devoção e patrocínio de causas "generalistas", como a da ecologia ou a da "proteção aos índios". Em políticos que começam sua carreira nos anos 1980, quando o fascínio da esquerda começa a enfraquecer, a ecologia aparece como a causa da humanidade, protegendo seus patrocinadores contra a acusação de particularismo ${ }^{33}$.

\section{(1987).}

${ }^{33}$ Nesse sentido é emblemática a figura do deputado federal por São Paulo Fabio Feldmann, eleito por várias legislaturas a partir de unia plataforma ecológica, e muito bem votado nos distritos eleitorais onde se concentra a comunidade judaica paulistana. Ele começa a sua carreira na política estudantil na Faculdade de Direito da USP e na Fundação Mata Atlântica, uma das primeiras organizações ecológicas do Brasil e atualmente ocupa o cargo de 


\section{Conclusão}

Os estudos comparativos fornecem-nos acesso a dimensões dos problemas étnicos que são pouco visíveis nos trabalhos de formato tradicional. A meu ver, o que podemos visualizar de mais importante na comparação entre armênios e judeus no Brasil é justamente a necessidade de procurar com cautela a forma que cada um dos grupos procura estabelecer a sua identidade. Se a derivarmos simplesmente da especialização econômica, seremos inapelavelmente pegos pela armadilha do reducionismo. Embora não independente da esfera da vida material, a produção de identidades dos grupos - fundamental como espaço de possibilidades de realização na vida profissional e afetiva de cada um de seus membros - é um fator que deve ser analisado em uma esfera própria. Nesse sentido, a camada de intelectuais leigos que se cria entre os judeus responde por grande parte do sucesso dessa construção.

Para os estudos judaicos em especial, creio que estou fornecendo dados que referendam a necessidade de analisar o anti-semitismo em perspectiva: em países que se formaram através da emigração de diversos povos, a lógica do estudo dos preconceitos contra os judeus só pode ser alcançada se colocarmos o anti-semitismo em relação com os prejulgados que prejudicaram as vidas de membros de outras etnias. Os grupos vindos do Oriente Médio são a comparação mais imediata, mas não podemos perder de vista os japoneses e coreanos, nem tampouco os indivíduos oriundos das intensas migrações internas do povo brasileiro. Da comparação surge um quadro muito interessante: é claro que existe antisemitismo no Brasil - esse sentimento é parte fundamental do repertório cultural das sociedades ocidentais. Mas por diversas razões o grupo judeu no Brasil soube utilizar a sua inserção nos espaços cultural e político brasileiros, atenuando seus efeitos maléficos. Em contrapartida, grupos que não têm/tinham a experiência internacional dos judeus no último século de luta contra o anti-semitismo, não obtiveram o mesmo sucesso. Um grande campo para pesquisas futuras é justamente o estabelecimento dessa perspectiva comparativa, que representaria um progresso não só para a

secretario de Estado para o Meio Ambiente em São Paulo. Seus adversários no movimento ecológico acusam-no de fazer unia "ecologia empresarial", aludindo a um possível patrocínio de suas campanhas pelos grandes empresários judeus do ramo de papel e celulose. sociologia da vicia intelectual e dos grupos étnicos, como também da dinâmica interna das comunidades judaicas. 


\section{Apêndice}

TABELA 1: Origem dos judeus que emigraram para o Brasil, segundo as agências judaicas (ICA e Alliance Israélite Internationale)

\begin{tabular}{|l|l|l|l|l|l|l|l|l|l|l|l|l|}
\hline $\begin{array}{l}\text { Ano/ } \\
\text { Origem }\end{array}$ & 1925 & 1926 & 1927 & 1928 & 1929 & 1930 & 1931 & 1932 & 1933 & 1934 & 1935 & $\begin{array}{l}\text { TOTAL } \\
\text { DO } \\
\text { PERí(n) }\end{array}$ \\
\hline Polônia & 802 & 1.009 & 1.095 & 1.290 & 2.795 & 1.168 & 753 & 931 & 1.920 & 1.746 & 1.130 & 14.609 \\
\hline $\begin{array}{l}\text { Alema- } \\
\text { nha }\end{array}$ & 0 & 0 & 0 & 0 & 0 & 0 & 0 & 0 & 363 & 835 & 357 & 1.555 \\
\hline Rússia & 225 & 283 & 286 & 315 & 0 & 0 & 0 & 0 & 0 & 0 & 0 & 1.109 \\
\hline Lituânia & 0 & 0 & 0 & 151 & 60 & 7 & 0 & 0 & 0 & 0 & 0 & 211 \\
\hline Romênia & 220 & 283 & 571 & 43 & 58 & 0 & 135 & 0 & 210 & 292 & 127 & 1.939 \\
\hline Outros & 0 & 0 & 0 & 0 & 0 & 0 & 0 & 0 & 824 & 921 & 144 & 1889 \\
\hline TOTAL & 1.690 & 3.154 & 3.175 & 4.874 & 3.558 & 1.985 & 2.049 & 3.317 & 3.794 & 3.794 & 1.758 & 32.521 \\
\hline
\end{tabular}

Fonte: J. LESSER. "The Immigration and Integration of Polish Jews in Brazil, 1924-1934". In: The Americas 51:2 October 1994, pp.173-191.

TABELA 2: Distribuição ocupacional da população judaica em São Paulo (1968)

\begin{tabular}{|l|l|}
\hline OCUPAÇÃO & PROPORÇÃO \\
\hline empregadores & $27,3 \%$ \\
\hline gerentes & $15,3 \%$ \\
\hline profissionais & $14,8 \%$ \\
\hline empregados & $12,7 \%$ \\
\hline artesãos & $8,5 \%$ \\
\hline aposentados & $7,9 \%$ \\
\hline operários & $6,3 \%$ \\
\hline desempregados & $2,7 \%$ \\
\hline outros & $10,0 \%$ \\
\hline
\end{tabular}

FONTE: H.RATTNER. Trudiç̄õo e Mudlança. São Paulo: Ed. Ática, 1978. Tabela n” 5

\section{Bibliografia}

ARTZRUNI, A. História do povo armênio. São Paulo: Ed. da Comunidade da Igreja Apostólica Armênia do Brasil, 1976.

BOLTANSKI, L. e THEVENOT, L. Les Economies de la Grandeur. Paris: Cahiers du CEE, n.31, serie Protée, 1987.

BOURDIEU, P. La distinction. Paris: Minuit, 1979.

La Noblesse d'Etat. Paris: Minuit, 1989.

COMISSÃO Organizadora do $75^{\circ}$ Aniversário do Genocídio Armênio. Armênia. São Paulo, 1990.

COMUNIDADE Armênia. História dos meus antepassados. São Paulo, 1980.

DOUGLAS, M. How Institutions Think. Syracuse: Syracuse University Press, 1987.

DUBY, G. "Au XII siècle: Les 'jeunes' dans la societé aristocratique”, Annales, n.19(6), 1964, pp.835-846.

ELIAS, N. La société de cour. Paris: Calmann-Lévy, 1974.

FAUSTO, B. A historiografia da imigração para São Paulo: questões e controvérsias. São Paulo: IDESP/Ed. Sumaré, 1991.

FAUSTO, B. et alii. Imigração e política em São Paulo. São Paulo: Ed. Sumaré/Fapesp, 1995.

FERNANDES, F. A Revolução burguesa no Brasil. Rio de Janeiro: Zahar, 1975.

GORDINHO, M.C. Gaspar Gasparian: um fotógrafo paulista. São Paulo: Ed. Marca D'Água, 1988 
GRUN, R. "La imagen y la vida de los judios en Brasil: cuestiones e inferências". Estúdios Migratorios Latinoamericanos, n” 29, 1995, pp.5-27.

KECHICHIAN, H. "A Imigração Armênia no Brasil, nos Estados Unidos e na Argentina". Jornal do Imigrante, Ano VII n.73, abril/maio 1984, p.7.

KERIMIAN, N. Massacres de Armênios. São Paulo: Ed. Comunidade da Igreja Apostólica Armênia, 1981.

LEVIN, E. Bom Retiro. São Paulo: Ed. Perspectiva, 1972.

MIRAK, R. "Armenians". In: THERNSTRON, S. (ed.) The Harvard Encyclopedia of American Ethnic Groups. Cambridge: Harvard University Press, 1980.

RAMAGEM, S.B. A Fênix de Abraão: um estudo sobre cristãos-novos retornados ao judaísmo de seus Ancestrais. Brasília: UNB, 1994.

SAINT-MARTIN, M. de. "Une grande famille", Actes de la Recherche en Sciences Sociales, n. 59, pp. 4-21, 1980.

SAPSEZIAN, A. História da Armênia: drama e esperança de uma nação. Rio de Janeiro: Paz e Terra, 1988.

TRUZZI, O.M.S. De mascates a doutores: sírios e libaneses em São Paulo. São Paulo: Ed. Sumaré/IDESP, 1991. 